\title{
Zagros orogeny: a subduction-dominated process
}

\author{
P. AGARD*†, J. OMRANI \\ W. SPAKMAN $\|$, P. MONIÉ\#, B. MEYER* \&R. WORTEL\| \\ *ISTEP, UMR 7193, Université Pierre et Marie Curie - Université Paris 6, 4 pl. Jussieu, Paris 75005, France \\ $\ddagger$ Geological Survey of Iran, Tehran, Iran \\ §ISTO, Université d'Orléans, France \\ ๆEOST, Strasbourg, France \\ \|Geosciences, Utrecht University, The Netherlands \\ \#Géosciences Montpellier, UMR 5573, Université Montpellier 2, France
}

(Received 17 January 2011; accepted 3 May 2011; first published online 5 July 2011)

\begin{abstract}
This paper presents a synthetic view of the geodynamic evolution of the Zagros orogen within the frame of the Arabia-Eurasia collision. The Zagros orogen and the Iranian plateau preserve a record of the long-standing convergence history between Eurasia and Arabia across the Neo-Tethys, from subduction/obduction processes to present-day collision (from $\sim 150$ to $0 \mathrm{Ma}$ ). We herein combine the results obtained on several geodynamic issues, namely the location of the oceanic suture zone, the age of oceanic closure and collision, the magmatic and geochemical evolution of the Eurasian upper plate during convergence (as testified by the successive Sanandaj-Sirjan, Kermanshah and Urumieh-Dokhtar magmatic arcs), the $P-T-t$ history of the few Zagros blueschists, the convergence characteristics across the Neo-Tethys (kinematic velocities, tomographic constraints, subduction zones and obduction processes), together with a survey of recent results gathered by others. We provide lithospheric-scale reconstructions of the Zagros orogen from $\sim 150$ to $0 \mathrm{Ma}$ across two SW-NE transects. The evolution of the Zagros orogen is also compared to those of the nearby Turkish and Himalayan orogens. In our geotectonic scenario for the Zagros convergence, we outline three main periods/regimes: (1) the Mid to Late Cretaceous (115-85 Ma) corresponds to a distinctive period of perturbation of subduction processes and interplate mechanical coupling marked by blueschist exhumation and upper-plate fragmentation, (2) the Paleocene-Eocene (60-40 Ma) witnesses slab break-off, major shifts in arc magmatism and distributed extension within the upper plate, and (3) from the Oligocene onwards $(\sim 30-0 \mathrm{Ma})$, collision develops with a progressive SW migration of deformation and topographic build-up (Sanandaj-Sirjan Zone: 20-15 Ma, High Zagros: 12$8 \mathrm{Ma}$; Simply Folded Belt: 5-0 Ma) and with partial slab tear at depths ( $10 \mathrm{Ma}$ to present). Our reconstructions underline the key role played by subduction throughout the whole convergence history. We finally stress that such a long-lasting subduction system with changing boundary conditions also makes the Zagros orogen an ideal natural laboratory for subduction processes.
\end{abstract}

Keywords: Zagros, geodynamics, orogeny, subduction, arc magmatism, obduction, slab break-off.

\section{Introduction}

The Zagros orogen stands at the tectonic crossroads of the Alpine-Himalayan belts. Its formation results from the long-standing convergence between Eurasia and Gondwanian-derived fragments, as underlined by ophiolite belts or present-day GPS vectors (Fig. 1a). The Zagros orogen hosts considerable oil resources and spectacular, world famous whaleback folds. Yet, despite a wealth of recent data on GPS displacements, active deformation and kinematics (e.g. Vernant et al. 2004; Walker, 2006; Le Dortz et al. 2009; Allen et al. 2011; Reilinger \& McClusky, 2010) or on the tectonosedimentary record (e.g. Sherkati, Letouzey \& Frizon de Lamotte, 2006; Mouthereau et al. 2007; Homke et al. 2009, 2010), the Zagros orogen remains much less documented than its adjacent counterparts (the Himalayas, Turkey or the Alps).

$†$ †uthor for correspondence: philippe.agard@upmc.fr
As for other segments of the Alpine-Himalayan belts, the Zagros collision zone formed as a result of the disappearance of the Neo-Tethys Ocean (e.g. Takin 1972; Ricou, Braud \& Brunn, 1977; Alavi 1980, 1994; Berberian \& King, 1981; Dercourt et al. 1986; Dercourt, Ricou \& Vrielynck, 1993; Sengör et al. 1988; Stampfli \& Borel, 2002; Agard et al. 2005; Hafkenscheid, Wortel \& Spakman, 2006) between Arabia and Eurasia (Fig. 1b). The timing of collision, however, has been highly controversial, ranging from Late Cretaceous (Berberian \& King, 1981) to Miocene (Berberian \& Berberian, 1981) or uppermost Pliocene (Stöcklin, 1968), to only mention cornerstone papers. Although there is a growing body of evidence in support of Late Eocene to Oligocene initial collision (e.g. Jolivet \& Faccenna, 2000; Agard et al. 2005; Vincent et al. 2005; Ballato et al. 2010 and references therein), very contrasting interpretations are still published (e.g. Ghalamghash et al. 2009; Mazhari et al. 2009b). The position of the suture zone itself, regarded by most authors to lie along the Main Zagros Thrust 


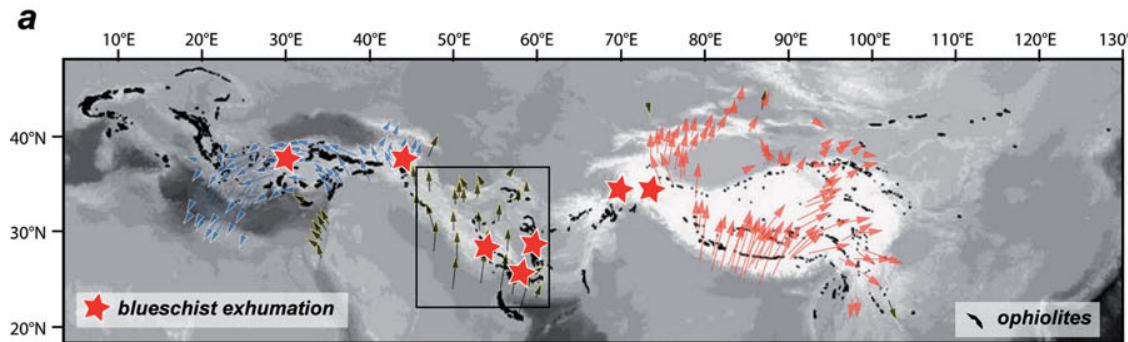

b
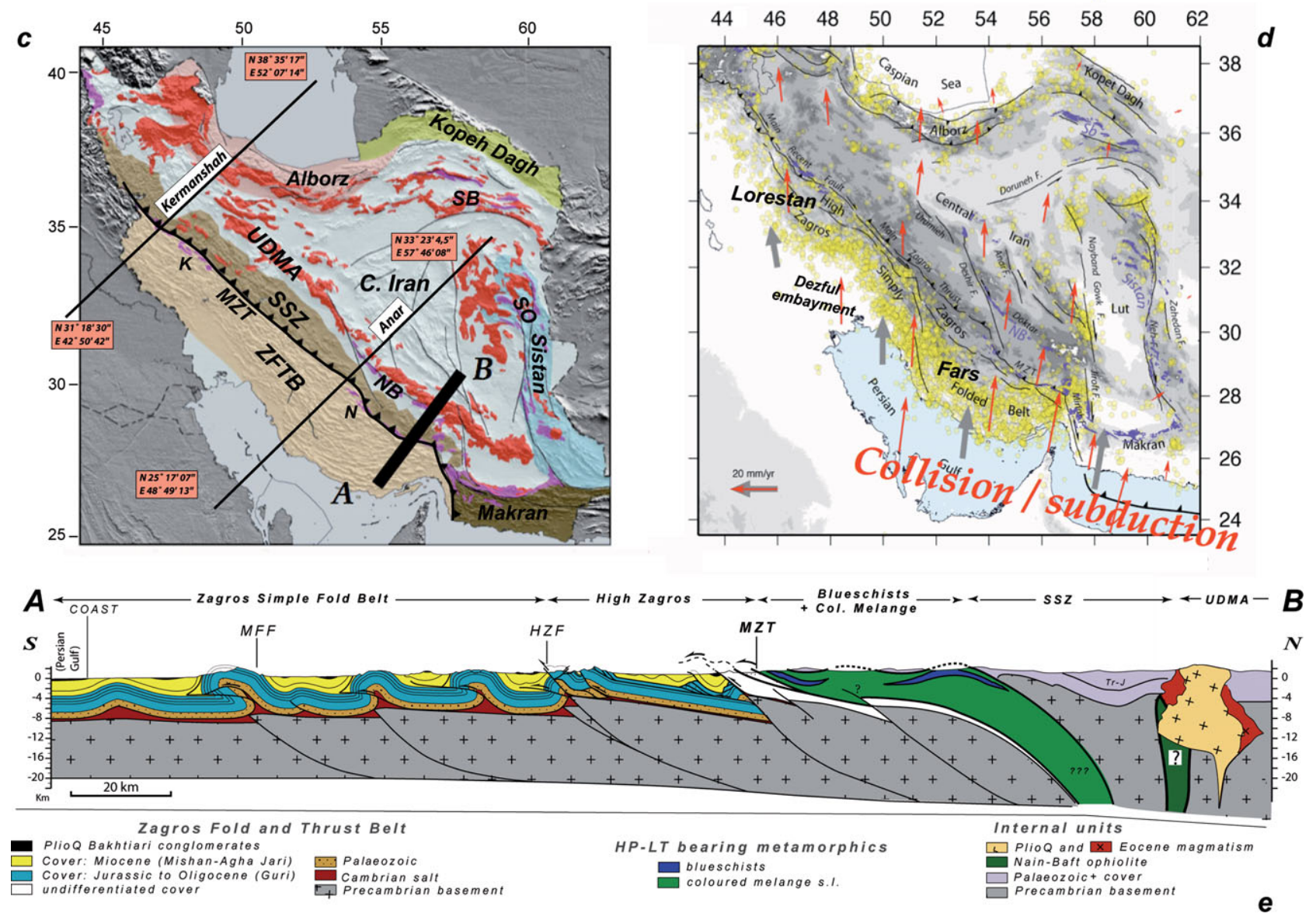

Figure 1. (Colour online) (a) The Zagros orogen: a central segment (at the tectonic crossroads) of the gigantic Alpine convergence zone from the Himalayas to the Western Mediterranean region. Present-day convergence underlined by GPS vectors (after Vernant et al. 2004). Finite convergence is underlined by ophiolites (in black; after Khan et al. 2006) sandwiched between the major tectonic domains and high-pressure, low-temperature rocks (red stars; mostly blueschists) returned from the Neo-Tethyan suture zone. Topography as background greyscale. Frame shows location of (b) and (c). (b) Simplified palaeogeographic reconstruction for the Neo-Tethys during Late Cretaceous time (c. $95 \mathrm{Ma}$; after Vrielynck \& Bouysse, 2003; Barrier \& Vrielynck, 2008). The location (and regional extent) of blueschist exhumation in the NSZ (Neo-Tethyan subduction zone) is compared with that of obduction to the south of the Neo-Tethys. (c) Simplified geological map of Iran showing the main tectonic subdivisions and locations discussed in the text. Also shown are the two transects (Kermanshah, Anar) whose lithospheric-scale reconstructions are shown in Figure 10 (corresponding tomographic sections are shown in Fig. 9). Abbreviations: K - Kermanshah; MZT - Main Zagros Thrust; N - Neyriz; NB - Nain-Baft; SB - Sabzevar; SO - Sistan ocean; SSZ - Sanandaj-Sirjan Zone; UDMA - Urumieh-Dokhtar Magmatic Arc; ZFTB - Zagros fold-and-thrust belt. (d) Present-day deformation of Iran, as seen through seismicity (yellow dots) and the location of major active faults (for deformation partitioning, see also Fig. 13a). GPS vectors shown in red. Note the transition from active oceanic subduction to collision across the Hormuz strait. (e) Section across the Zagros orogen (location shown in (c)), showing the spectacular deformation of the ZFTB, the presence of high-pressure, low-temperature rocks in the suture zone, and the main domains found in the upper Eurasian plate (i.e. SSZ, Nain-Baft, UDMA, Central Iran; after Agard et al. 2006). Abbreviations: HZF - High Zagros Fault; MFF - Main Front Fault; MZT - Main Zagros Thrust; SSZ - Sanandaj-Sirjan Zone; Tr-J - Triassic to Jurassic cover of SSZ and Central Iran; UDMA Urumieh-Dokhtar Magmatic Arc. See text (in particular Section 3) for details.

(MZT; Fig. 1c; Stöcklin, 1968; Ricou, Braud \& Brunn, 1977; Agard et al. 2005, 2006; Paul et al. 2006, 2010), is also still discussed (Alavi, 1994; Shafaii Moghadam, Stern \& Rahgoshay, 2010). Finally, compared to our understanding of active tectonics and foreland deformation, much less is known about the hinterland, subduction-related arcs trending parallel to the Zagros, namely the Sanandaj-Sirjan Zone (SSZ) and the Urumieh-Dokhtar Magmatic Arc (UDMA; Fig. 1c). 
A number of questions therefore remain unanswered or unsettled: when did initial collision and shortening happen, and was it diachronous along strike? How was deformation partitioned in space and time? Did one or several slab break-offs occur (i.e. fragmentation and sinking of a piece of subducting oceanic slab; von Blanckenburg \& Davies, 1995)? How can the changing patterns of arc magmatism be explained? And, more fundamentally, can the Zagros be considered a model of immature collision, such as a young Himalayas or Turkey (Fig. 1a; i.e. with a smaller plateau and perhaps a younger collision; Hatzfeld \& Molnar, 2010)? What are the detailed links between the Zagros build-up and the overall Neo-Tethyan history (Fig. 1b) or with the rest of Iran (Fig. 1c)? What are the respective contributions of subduction and collision stages to the formation of this orogenic belt?

The aims of the present paper are thus to provide (1) a review of our present knowledge of the Zagros orogen and (2) lithospheric-scale reconstructions in 2D along two parallel, SW-NE transects across the Zagros, with emphasis on the constraints derived from the internal zones. We first present a synthetic overview of the geological data available on the Zagros orogen, and then outline the major events that any lithospheric reconstruction of the Zagros orogen should account for. We then present our reconstructions, discuss them and outline specific points of focus (history and geodynamics, upper plate deformation, comparison with Neo-Tethyan orogens). We will attempt to demonstrate that the Zagros orogeny is in fact largely governed by subduction processes.

\section{Overview of the Arabia-Eurasia convergence across the Zagros}

\section{2.a. Regional extent and tectonic subdivisions}

The Zagros orogen extends from the Turkish-Iranian border to the NW, to the Makran area in the SE (where oceanic subduction is still active; Ellouz-Zimmermann et al. 2007; Smit et al. 2010b; Fig. 1c, d). In an orographic sense, the Zagros orogen comprises the following sub-parallel tectonostratigraphic domains, from SW to NE: the Zagros foreland basin, the Simply Folded Belt, the more mountainous part of the Zagros proper (including the High Zagros and the Crush Zone) as well as domains that can be thought of belonging to the Zagros orogen in a broader sense: the SSZ (or Central Iranian active margin; Berberian \& King, 1981), the UDMA and the western parts of Central Iran (Fig. 1e).

The interested reader is referred to Stöcklin (1968) for historical tectonic subdivisions of the Zagros orogen. The Zagros was initially considered to lie to the SW of the MZT by Stöcklin (1968), whereas he referred to the part to the NE of the MZT as Central Iran. This latter part was later termed the internal Zagros (Reyre \& Mohafez, 1970; J. Braud, unpub. Ph.D. thesis, Univ. Paris-Sud, 1987), emphasizing, as already recognized by Stöcklin, the importance of Tertiary deformation over the whole of Iran. In fact, several other adjacent domains located in the far-field of Zagros deformation should be considered whenever studying the Zagros orogeny (e.g. Jackson, Hains \& Holt, 1995): these are the Alborz, Kopet Dagh, Central Iran and Sistan regions (Fig. $1 \mathrm{c}, \mathrm{d}$ ). We will indeed show that the history of the Zagros orogeny largely overlaps with the deformation history of most of Iran since the Jurassic. All these domains are further described in what follows (Section 3).

It is convenient, however, to outline from the start a more fundamental division, between a lower and an upper lithospheric plate. Calc-alkaline, arc-related magmatism found in the SSZ and UDMA (Fig. 2) provide compelling evidence for past convergence and northward subduction of the Neo-Tethys Ocean (now vanished everywhere but in front of the accretionary prism of Makran) below Eurasia (Fig. 1b; Berberian \& Berberian, 1981).

This boundary between the upper (Eurasia) and lower (Arabia) plates runs along the MZT (Fig. 2), as supported by the presence of ophiolite fragments (Ricou 1971; Ricou, Braud \& Brunn, 1977), highpressure, low-temperature, mainly blueschist facies rocks (Sabzehei et al. 1994; Agard et al. 2006), the style of deformation (Agard et al. 2005) and seismic profiles tracing this thrust down to Moho depths (Paul et al. 2006, 2010). It can be useful to recall that Alavi (1994) proposed an alternative location for the suture zone between the SSZ and the UDMA, because this option was considered in a number of later publications and only recently refuted (Agard et al. 2005; Paul et al. 2006).

The MZT thus defines the boundary between the Arabian, lower plate external zones to the SW and the Eurasian, upper plate internal zones to the NE (cross-section Fig. 1e, Fig. 2). We give below a brief overview of the various domains, for which synthetic stratigraphic columns of the Zagros (Arabia) and Central Iran (Eurasia) are shown in Figure 3 (and for which a wealth of papers are available; for details, see more in-depth publications, e.g. James \& Wynd, 1965; Motiei, 1993; Homke et al. 2009). Emphasis will be placed here on the internal zones, which provide crucial constraints for the geodynamic evolution of the Zagros orogen. All domains share a common Infracambrian to Middle Triassic $\sim 3 \mathrm{~km}$ thick sequence of platform deposits, very constant throughout Iran (Stöcklin, 1968), overlying a presumably Arabian-type basement structured during late Precambrian 'Assyntic' or PanAfrican times (Hassanzadeh et al. 2008). Some N-S trends (Oman line and Qatar high; Gansser, 1960), and possibly even early NW-SE trends (e.g. controlling the deposition of the Cambrian Hormuz salt), are thought to be inherited from these deformation episodes. No significant deformation affected Iran during Palaeozoic times, apart from the Permian-Triassic rifting which gave birth to the Neo-Tethys. Major contrasts on either side of what is now the MZT formed from Late Triassic time onwards. 

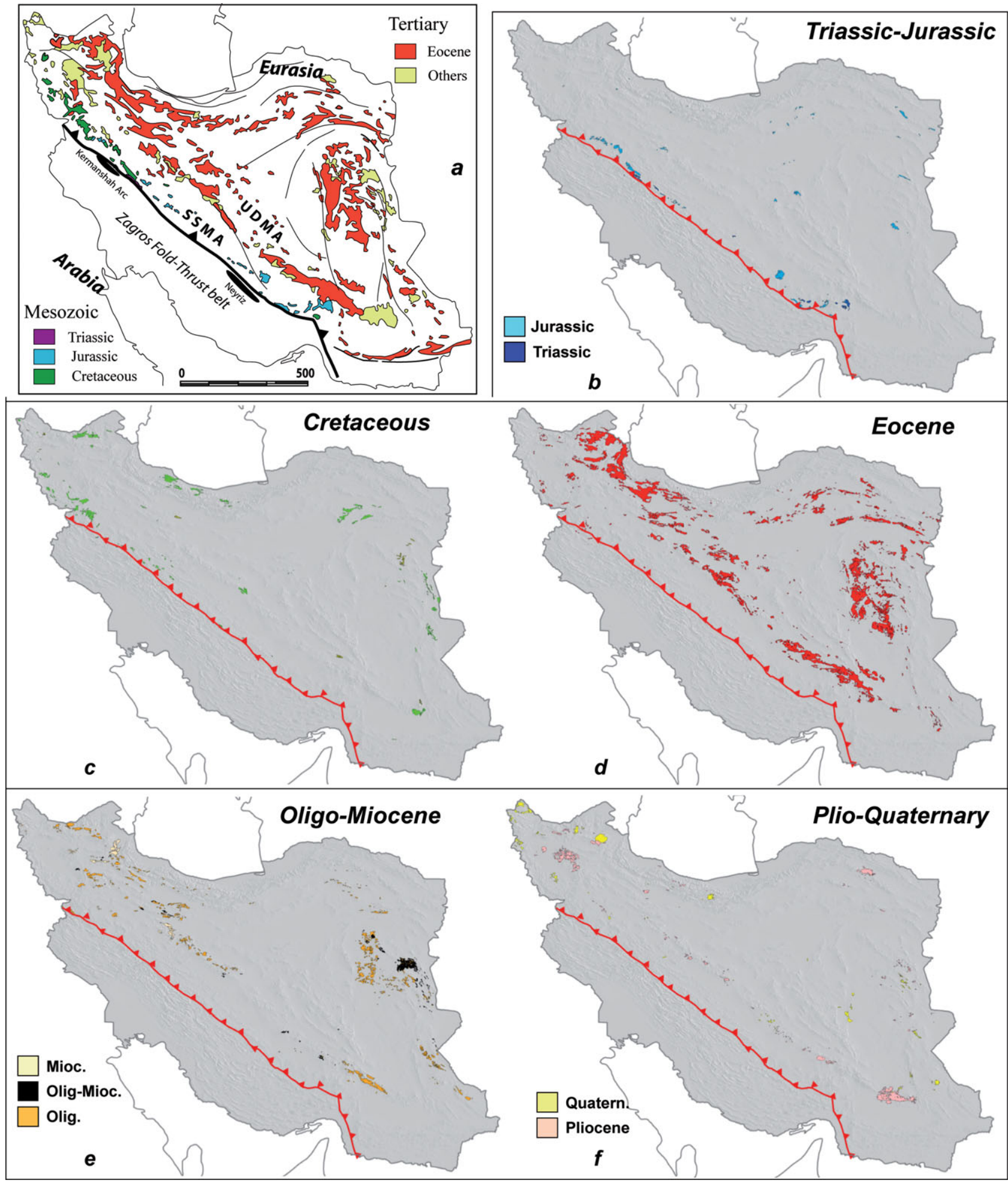

Figure 2. (Colour online) Compilation of magmatism in Iran through time (upper Eurasian plate) through 250000 scale maps from the Geological Survey of Iran.

Before recalling essential characteristics of the various palaeogeographic domains, we start by giving an outline of the present-day deformation patterns as seen by GPS and tracking of active faults.

\section{2.b. Present-day partitioning of the deformation through the Zagros orogen}

Present-day kinematics indicates a northward motion of the Arabian plate relative to Eurasia of $22 \pm 2 \mathrm{~mm} \mathrm{yr}^{-1}$
(Vernant et al. 2004). GPS vectors reveal that the overall present-day strain field across the Zagros, in response to the Arabia-Eurasia convergence, is directed $\mathrm{N}-\mathrm{S}$ to N010 on average (Fig. 1b, d; Masson et al. 2007), that is, oblique by $\sim 20-30^{\circ}$ to the principal long-term SWNE shortening direction across the orogen (Fig. 1d). Northward convergence is accommodated (Jackson, Hains \& Holt, 1995; Allen et al. 2006; Hatzfeld \& Molnar, 2010) through a combination of: 

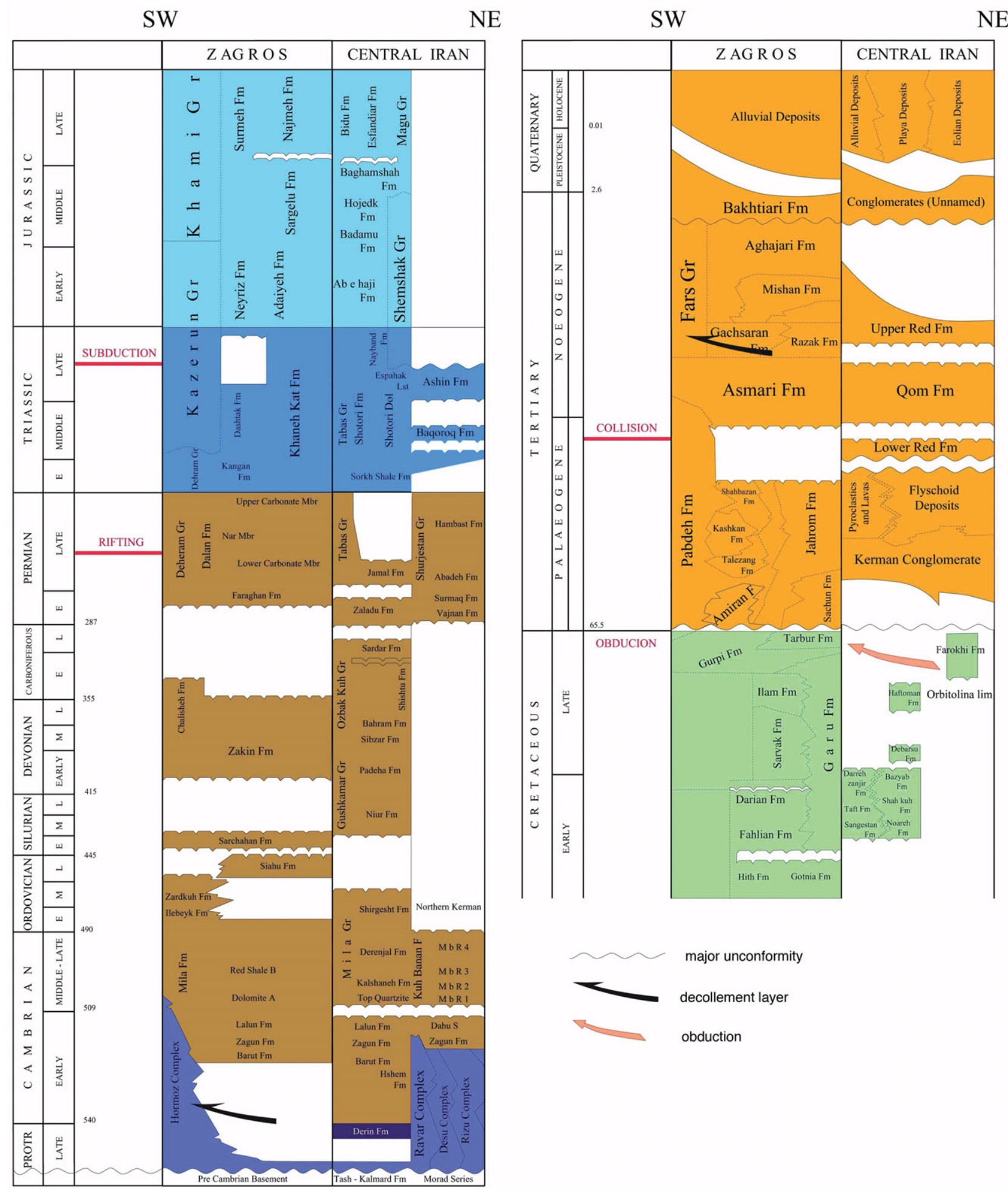

Figure 3. (Colour online) Simplified stratigraphic columns for the ZFTB (see also Alavi, 2007, fig. 8) and for Central Iran. Modified after Aghanabati \& Rezai (2009).

(1) across-range shortening in the Zagros orogen and in far-field domains (Alborz, Kopet Dagh) at rates of $5 \pm 2 \mathrm{~mm} \mathrm{yr}^{-1}$ (McClusky et al. 2000; Vernant et al. 2004; Walpersdorf et al. 2006; Masson et al. 2007). Deformation was concentrated in the Zagros and the Alborz since Pliocene time at least (Oveisi et al. 2009; Allen et al. 2011) at a probably constant rate over the last $5 \mathrm{Ma}$ (Lacombe et al. 2006, 2007). Out of the $\sim 2 \mathrm{~cm} \mathrm{yr}^{-1}$ of overall orogen-normal shortening component, two thirds are taken up in the Zagros foldand-thrust belt (ZFTB) and one third in the Alborz, with domains such as the SSZ behaving more rigidly (Masson et al. 2007).

(2) dextral strike-slip movements across the Main Recent Fault (MRF; 3-15 $\mathrm{mm} \mathrm{yr}^{-1}$; Talebian \& Jackson, 2002, 2004; Authemayou et al. 2009), the Kazerun fault (Authemayou et al. 2006, 2009) and subordinate faults east of the Kazerun fault proper 
(Lacombe et al. 2006). Several N-S-trending faults also cut across the Iranian plateau (e.g. from west to east: the Deshir, Anar, Nayband-Gowk and Ney faults; Walker \& Jackson, 2002; Regard et al. 2004; Meyer et al. 2006; Meyer \& Le Dortz, 2007; Le Dortz et al. 2009).

Overall, deformation partitioning across Iran can be viewed as shown in Figure 1d. The predominance of N-S dextral strike-slip faults to the east of the Kazerun-Doruneh faults could correspond to Iran moving north with respect to stable Afghanistan and/or to the existence of a somewhat freer boundary in the still subducting Makran region (at least before Pliocene time; Allen et al. 2011; Regard et al. 2010; Smit et al. $2010 \mathrm{~b}$ ). Some of these major faults represent long-lived structures, such as the MRF or the Neh fault, which both reactivate suture zones (Talebian \& Jackson, 2002; Walker et al. 2009).

\section{Geological setting of the main palaeogeographic domains}

\section{3.a. The Zagros fold-and-thrust belt}

The Zagros fold-and-thrust belt (ZFTB) classically comprises the geographic provinces of Lurestan and Fars separated by the Dezful Embayment (Fig. 1d). The ZFTB can be divided into two distinct domains from the SW to NE (Fig. 4a), with major changes in structural style and topography: (a) the Simply Folded Belt (SFB) is found in the vicinity of the Persian Gulf and shows fairly regular wavelength folds running along hundreds of kilometres (Falcon, 1974; Sepehr \& Cosgrove, 2004; Mouthereau, Lacombe \& Meyer, 2006). The SFB is in fact also cut by several hidden major faults and progressively steps up in elevation towards the NE (Berberian, 1995; Leturmy, Molinaro \& Frizon de Lamotte, 2010); (b) the High Zagros shows higher elevation, a sharp increase in elevation and kilometre-scale throws on major thrusts.

The ZFTB essentially corresponds to the EoCambrian to Quaternary cover of the Arabian plate deformed above the Arabian basement, with a maximum thickness of 12-13 km (James \& Wynd, 1965; Motiei, 1993; Alavi, 2007) and a deeper Zagros distal basin individualized since Late Triassic time. This sedimentary cover dominantly comprises shelf carbonates, together with several evaporitic low viscosity layers (i.e. Cambrian Hormuz salt and the Early-Middle Miocene Gachsaran Formation; Sherkati et al. 2005; Fig. 3), which acted as major mechanical decollement horizons, thickened fold hinges and favoured spectacular thin-skinned deformation (Blanc et al. 2003; McQuarrie, 2004; Sherkati et al. 2005). Thin-skinned deformation produced regular fold wavelengths (i.e. $\sim 15 \mathrm{~km}$ ), yet only accounts for a subordinate amount of the overall deformation (Agard et al. 2006; Fig. 1e). Numerous salt diapirs from the Cambrian Hormuz salt formation, found to the $\mathrm{SE}$ of a N-S line coincident with the Qatar High, also strongly influenced heat advection in the ZFTB (and the extent of oil preservation; Haynes \& McQuillan, 1974; Jahani et al. 2009), and halokinesis mechanisms and duration are still debated (Koyi et al. 2008; Jahani et al. 2009).

From bottom to top, other important time markers are (Fig. 3):

(i) The Paleocene Amiran flysch (James \& Wynd, 1965; J. Braud, unpub. Ph.D. thesis, Univ. Paris-Sud, 1987; Homke et al. 2009), which contains ophiolitic fragments including clasts of serpentinite, radiolarite and mafic rocks in the Amiran anticline (James \& Wynd, 1965), but mainly radiolarites further to the NE (J. Braud, unpub. Ph.D. thesis, Univ. Paris-Sud, 1987). It is thought to represent the frontal foredeep of the Late Cretaceous obduction nappes, whose remnants can be found in Kermanshah, Neyriz and in Oman (Ricou, 1971; Coleman, 1971). This early syntectonic basin is found only in Lurestan and in Iraq, however, and is somewhat younger than its counterpart in Oman (Maastrichtian Muti Formation, Oman; Robertson, 1987).

(ii) A hiatus in sedimentation from the Lower Eocene to the Oligocene (Homke et al. 2009), which could result from forebulge flexural deformation (Mouthereau et al. 2007).

(iii) Shallow water platform carbonates of the Lower Miocene Asmari Formation (Motiei, 1993), showing a large extension (even into Central Iran, where its equivalent is known as the Qom Fm). This Lower Miocene formation is associated with high sea level and worldwide marine transgressions (Haq, Hardenbol $\&$ Vail, 1987).

(iv) Syn-orogenic deposits with growth strata, from the upper Agha Jari onwards (from 10 Ma onwards).

(v) Coarse-grained basin fill known as Bakhtyari conglomerates, classically assumed to be Upper Pliocene to Quaternary along the Zagros (James \& Wynd, 1965; Homke et al. 2004).

Revised age constraints, however, point to significant diachronism for the Bakhtyari conglomerates, as well as for the Agha Jari Formation (Fakhari et al. 2008; Khadivi et al. 2010). These syn-orogenic deposits are thus probably more diachronous along and across strike than acknowledged or demonstrated at present (in line with the fact that, for example, collision started earlier in Turkey than in the NW Zagros or that subduction is still active in Makran).

Renewed fieldwork and exploration since the 1990s have provided a number of shortening estimates for the ZFTB (Fig. 4a). Overall estimates are about $60 \pm$ $20 \mathrm{~km}$, without clear evidence for any gradient along strike (Fig. 4a; Sherkati, Letouzey \& Frizon de Lamotte, 2006), despite quite distinct widths on either side of the Dezful Embayment. This observation suggests that these contrasting widths rather relate to variations in the stratigraphic column (such as the presence of deep salt to the SE of the Kazerun fault; Koop et al. 1982; Bahroudi \& Koyi, 2003; Sherkati, Letouzey \& Frizon de Lamotte, 2006) than to distinct overall shortening estimates. Several authors have also 

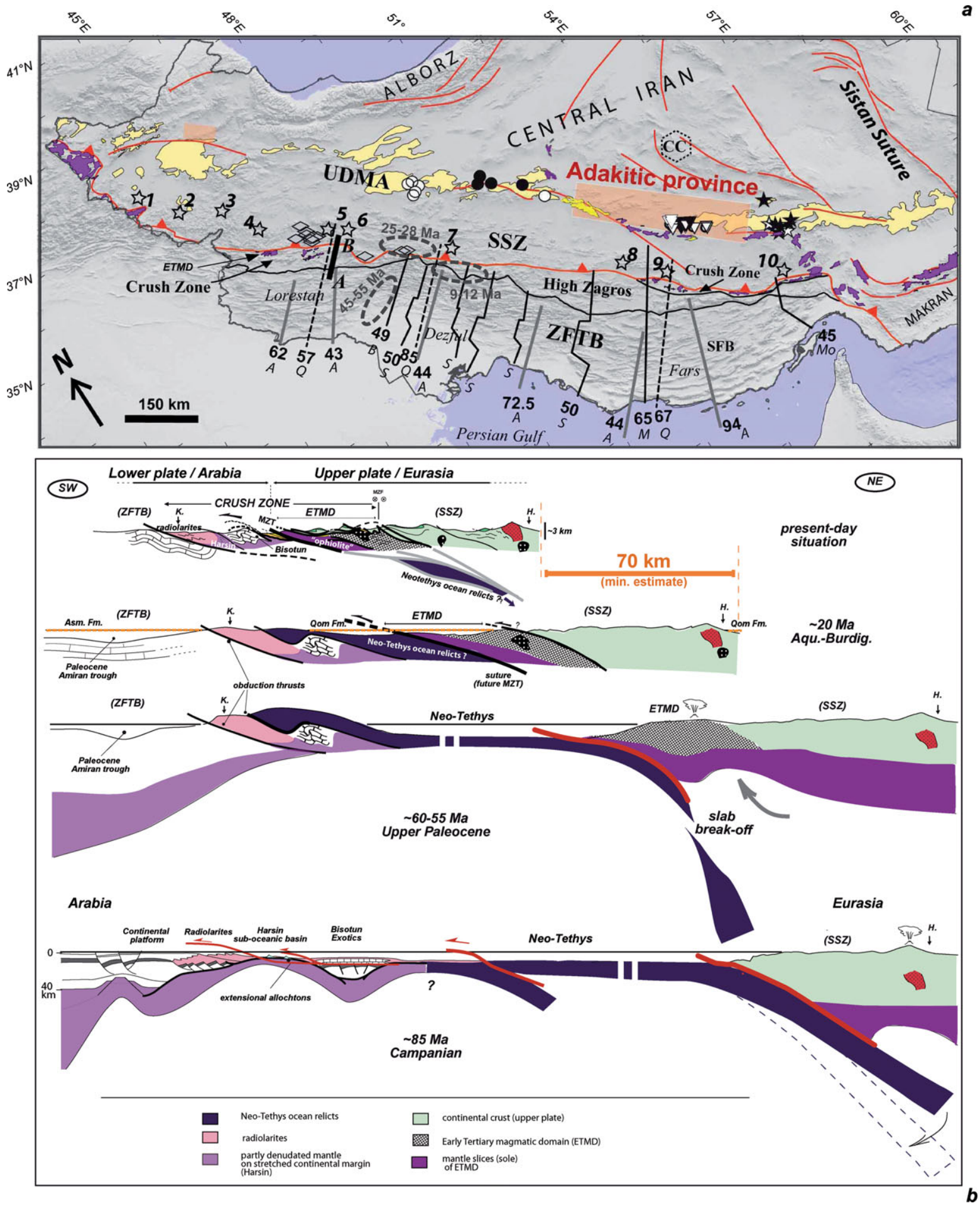

Figure 4. (Colour online) (a) Map of the Zagros orogen. Compilation of shortening estimates (bold numbers, in kilometres) from recently published cross-sections (A: Alavi, 2007; B: Blanc et al. 2003; M: Mouthereau et al. 2007; Mo: Molinaro et al. 2005; Q: McQuarrie, 2004; S: Sherkati, Letouzey \& Frizon de Lamotte, 2006). Empty stars with numbers locate available radiometric datings for the SSZ, which are shown in Figure 5c. Other symbols correspond to reference geochemical data given in Figure 5a, $\mathrm{b}$ (as in Omrani et al. 2008): black and white symbols refer to Eocene and Upper Miocene to Plio-quaternary UDMA samples, respectively, whereas diamonds correspond to SSZ samples. Places where adakites are found in the UDMA are shown with an orange rectangle. Grey dotted ellipses recall the age range obtained from apatite fission-track and U-Th-He data (after Gavillot et al. 2010; Homke et al. 2010; J. Omrani, unpub. Ph.D. thesis, Institut des Sciences de la Terre, Paris, 2008). Abbreviations: CC - core-complexes ETMD - Early Tertiary Magmatic Domain; SFB - Simply Folded Belt; SSZ, UDMA, ZFTB - as for Fig. 1c. Ophiolitic bodies in purple. (b) Section across the Crush Zone in the Kermanshah region (A-B shown on (a)) and tectonic evolution since Late Cretaceous time. Adapted from Agard et al. (2005) and Omrani et al. (unpub. data), and Wrobel-Daveau et al. (2010) for the Late Cretaceous stage. Abbreviations: ETMD - Early Tertiary Magmatic Domain; H - Hamadan; K - Kermanshah; MZT, SSZ, ZFTB - as for Fig. 1c, e. Note how little is left from the Neo-Tethyan ophiolite: much (if not all) of the peridotites correspond to the basement of the ETMD and to earlier stretched sub-continental mantle from the Arabian margin. Also note that $70 \mathrm{~km}$ is a minimum shortening estimate since internal ductile deformation cannot be constrained precisely. Plutons in the SSZ are already largely exhumed at 20 Ma, as shown by fission-track data (Fig. 4a). 
underlined, based on restoration models, that much of the distal part of the Arabian continental margin is missing (Molinaro et al. 2005; Mouthereau et al. 2007). Whether deformation evolved from thin-skinned to thick-skinned after the Mio-Pliocene (Molinaro et al. 2005) or whether both were already more or less coevally superimposed (Mouthereau et al. 2007; Ahmadhadi, Lacombe \& Daniel, 2007) is still a matter of debate.

Younger SW-directed folds and thrusts are recognized in the ZFTB when moving from NE to SW (e.g. Stocklin, 1968; Hessami et al. 2001; Molinaro et al. 2005). The High Zagros is distinct from the SFB in terms of structural style: it is characterized by earlier deformation, larger offsets on basement faults, steep contacts and more ductile deformation (Ricou, Braud \& Brunn, 1977). Shortening is also concentrated mostly in frontal folds on Pleistocene time scales (Navabpour, Angelier \& Barrier, 2007; Oveisi et al. 2009). This contrast between the ZFTB and the SFB is confirmed by recent apatite fission-track and $\mathrm{U}-\mathrm{Th}-\mathrm{He}$ constraints obtained on the timing of uplift (Homke et al. 2009; Gavillot et al. 2010; Axen et al. 2010; Fig. 4a), indicating that the High Zagros was uplifted since c. $10 \mathrm{Ma}$ (Gavillot et al. 2010). The SFB, by contrast, may have suffered $2-$ $4 \mathrm{~km}$ of uplift on average from balanced cross-sections (Mouthereau, Lacombe \& Meyer, 2006; Leturmy, Molinaro \& Frizon de Lamotte, 2010, fig. 11), but apatite fission-track ages were not reset (Fig. 4a), suggesting that $T$ did not exceed $\sim 100^{\circ} \mathrm{C}$ (hence burial $<2-3 \mathrm{~km}$ ) since onset of the current deformation stage.

\section{3.b. The Crush Zone: the Zagros suture zone}

The Crush Zone (Fig. 4a; Wells, 1969; Alavi, 1994; J. Omrani, unpub. Ph.D. thesis, Institut des Sciences de la Terre, Paris, 2008; also known as the Thrust Zone by Stöcklin, 1968 or Imbricated Zone by Falcon, 1967) shows extensive thrusts with steep fault contacts and is partly similar to the High Zagros in terms of topography and deformation style. The Crush Zone, however, comprises distinctive geological units which do not belong to the Arabian platform proper and are bounded by the MZT to the NE. The MZT was already considered a major boundary between Arabia and Iran by Stöcklin (1968), prior to the recognition of plate tectonics in the area, and regarded as the suture zone since Berberian \& King (1981).

In the Crush Zone near Kermanshah (Fig. 1c), several units are thus stacked on top of the ZFTB and in turn overlain by the SSZ. From bottom to top (Braud, 1978, unpub. Ph.D. thesis, Univ. Paris-Sud, 1987; Fig. 4b, present section), one finds: (a) Liassic to Cretaceous radiolarite basins (Gharib \& de Wever, 2010; as for their Pichakun equivalents in Neyriz; Robin et al. 2010), (b) thick Mesozoic platform carbonates (e.g. Bisotun limestone, considered an equivalent of the Oman 'Exotics'; J. Braud, unpub. Ph.D. thesis, Univ. Paris-Sud,
1987; Pillevuit et al. 1997), (c) presumably ophiolitic remnants (both in Kermanshah and Neyriz), and (d) an Early Tertiary Magmatic Domain (ETMD, hereafter).

Structural style, timing of deformation, rough balancing and shortening rates across the Crush Zone were given, for the Lurestan region, by Agard et al. (2005). Together with recent findings on the Crush Zone (Wrobel-Daveau et al. 2010), they are recalled in Figure 4b. A crucial observation is that major contacts, including the ophiolite/ETMD, are sealed by the Lower Miocene Qom Formation. This indicates that Arabia-Eurasia collision, marked by the juxtaposition of domains previously situated on both sides of the Neo-Tethys (i.e. plates in contact), must have started prior to the deposition of the Qom Fm (Agard et al. 2005), and thus pre-dates the lowermost Miocene. On the other hand, gabbroic intrusions emplaced in the (upper plate) ETMD only (i.e. Tah intrusion in the Kamyaran region dated at $34 \pm 1 \mathrm{Ma}$ with wholerock $\mathrm{Rb}-\mathrm{Sr}$; Leterrier, 1985), bracket collision to be uppermost Eocene to Oligocene. This observation is consistent with recent findings by Fakhari et al. (2008) and Homke et al. (2009; see also discussions by Allen \& Armstrong, 2008 and Ballato et al. 2010). Pre-Miocene deformation patterns in the Crush Zone also suggest the existence of early dextral strike-slip movements (Agard et al. 2005).

Ophiolitic remnants from the Crush Zone are considered equivalent to the Oman ophiolite and to have been emplaced onto Arabia (Ricou, 1971) as a result of obduction processes over the period 95$70 \mathrm{Ma}$. Only limited radiometric $\mathrm{K}-\mathrm{Ar}$ or $\mathrm{Ar}-\mathrm{Ar}$ age constraints are available for the Kermanshah and Neyriz ophiolites, yet cluster at $85 \pm 5 \mathrm{Ma}$ (Delaloye \& Desmons, 1980; J. Braud, unpub. Ph.D. thesis, Univ. Paris-Sud, 1987) and $90 \pm 15 \mathrm{Ma}$ (Lanphere \& Pamic, 1983; M. R. Jannessary, unpub. Ph.D. thesis, Univ. Louis Pasteur de Strasbourg, 2003; $92.1 \pm 1.7 \mathrm{Ma}$ and $93.2 \pm 2.5 \mathrm{Ma}$, Babaei et al. 2006). Kermanshah and Neyriz ophiolites significantly differ, however, from the oceanic lithosphere found in Oman (Coleman, 1971, 1981; Glennie et al. 1973): they correspond to fragments from the southern footwall of the NeoTethyan margin for Neyriz (M. R. Jannessary, unpub. Ph.D. thesis, Univ. Louis Pasteur de Strasbourg, 2003; for a different interpretation see Sarkarinejad, 2005) and at least partly for Kermanshah too (J. Omrani, unpub. Ph.D. thesis, Institut des Sciences de la Terre, Paris, 2008; Wrobel-Daveau et al. 2010; J. Omrani et al. unpub. data). Part of the Kermanshah ophiolite (near Harsin; Fig. 4b) shows an ocean island-arc signature (Fig. 5a; J. Omrani et al. unpub. data) and in fact rather corresponds to a small oceanic basin located between the radiolarite basin and the Bisotun limestone (the latter representing oceanic islands partly built on a peridotitic substrate; J. Braud, unpub. Ph.D. thesis, Univ. Paris-Sud, 1987). Some authors have recently advocated for the existence of extensional allochthons in the area (Wrobel-Daveau et al. 2010; see the Late Cretaceous section in Fig. 4b). In any case, no true 

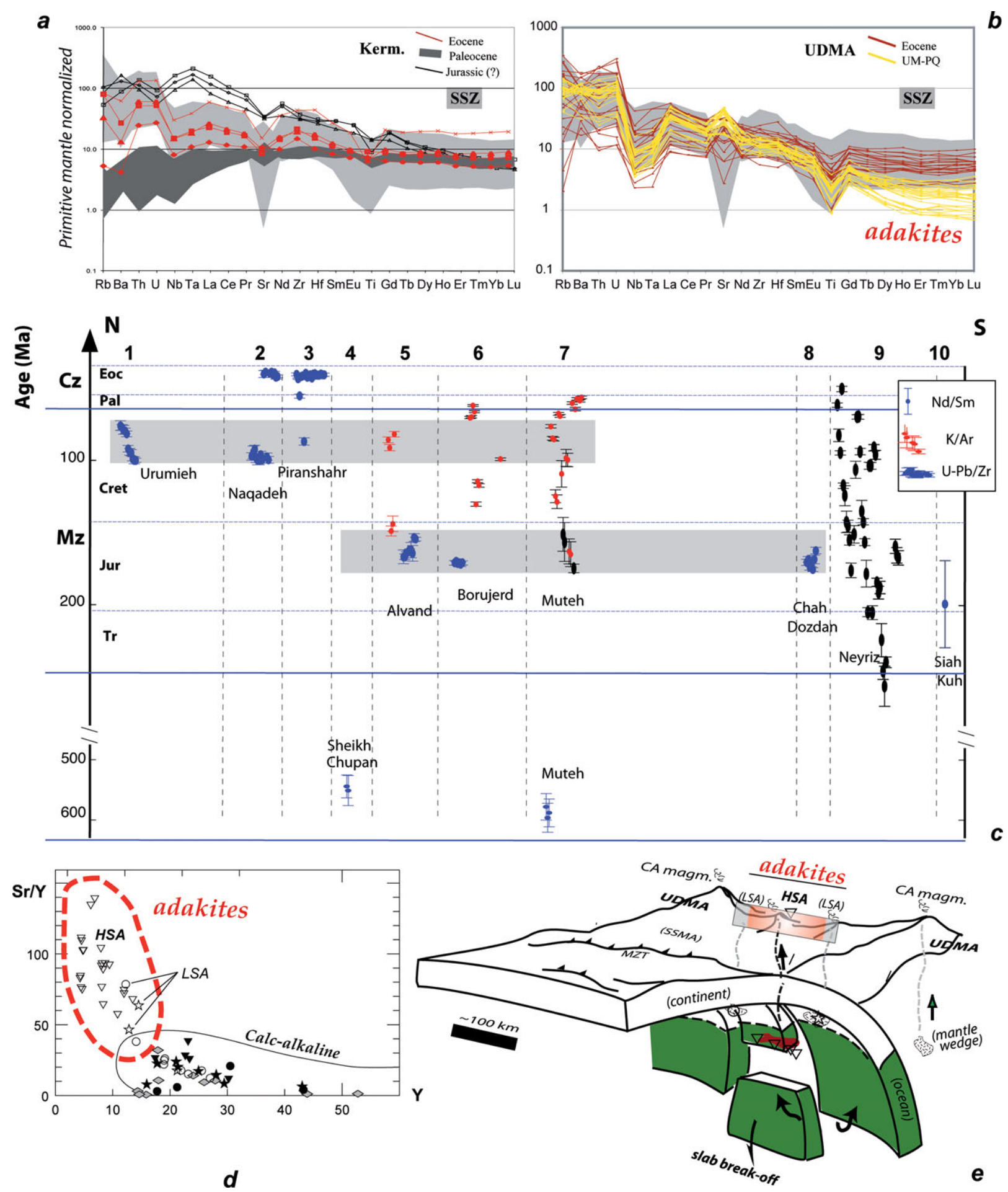

Figure 5. (Colour online) (a, b) Reference geochemical data for the Crush Zone (Omrani et al. unpub. data) and the internal zones (Omrani et al. 2008; see location in Fig. 4a). Grey overlay: typical variations of trace element multielement patterns for the SSZ, for comparison with other units. UM-PQ - Upper Miocene to Plio-Quaternary. (c) Age compilation of available radiometric constraints for the SSZ (after Ahmadi Khalaji et al. 2007; Arvin et al. 2007; Baharifar et al. 2004; Fazlnia et al. 2007; Ghalamghash et al. 2009; Hassanzadeh et al. 2008; Masoudi, Yardley \& Cliff, 2002; Mazhari et al. 2009a,b; Rachidnejad-Omran et al. 2002; Shahbazi et al. 2010; Sheikholeslami et al. 2003). (d) Discriminant diagram (Defant \& Drummond, 1990) for the Zagros (UDMA) adakites (after Omrani et al. 2008; same symbols as Fig. 4a). (e) Interpretation of the adakitic magmatism in terms of slab break-off: HSA (high-silica adakites) corresponding to slab melts (Martin et al. 2005) are located in the centre only, whereas LSA (low silica adakites) corresponding to mantle wedge melts contaminated by slab components are found on the edges of the adakitic region. See Omrani et al. $(2008,2009)$ for a detailed discussion.

mid-ocean ridge (MORB)-type ophiolitic material such as in Oman has been found so far in the Kermanshah ophiolite (Ghazi \& Hassanipak, 1999; J. Omrani et al. unpub. data), suggesting that much (if not all) of the Neo-Tethyan ophiolite has either been eroded and/or later buried (Fig. 4b). 
The ETMD is well exposed near Songor and Kangavar, to the N and NW of Kermanshah, and is generally considered a lateral equivalent of the Maden complex in Turkey (Braud \& Ricou, 1975). Intercalated sediments, sheared serpentinites, large gabbroic intrusions and mainly andesitic volcanics indicate that this ETMD formed during PaleoceneEarly Eocene times on the Eurasian side of the NeoTethys (to the south of the SSZ), on a partly peridotitic substratum. They also show an evolution in time from a back-arc to arc signature (Fig. 5a; J. Omrani et al. unpub. data). Volcanic rocks with a similar arc signature also lie between the ophiolite and the SSZ near Neyriz (Babaie et al. 2001), in a probably uppermost Cretaceous melange. It is yet unclear, however, whether they are equivalent to the ETMD, to the crustal section of the Neyriz ophiolite or even to the coloured melange found further to the SE (where high-pressure (HP) rocks are found in places, as described in the following).

In the southeasternmost part of Zagros, restricted blueschist exposures are indeed found sandwiched between the High Zagros and the SSZ, thus in a position equivalent to the Crush Zone (Fig. 1e; Agard et al, 2006; Oberhänsli et al. 2007). These Zagros blueschists correspond to tectonic slices lying within a more extensive 'coloured melange' (Gansser, 1960) made of serpentinites, radiolarites and lower greenschist facies metabasalts. These blueschists reached maximum depths of $30-40 \mathrm{~km}$, on average, for temperatures between 500 and $550{ }^{\circ} \mathrm{C}$. Most importantly, they yield ${ }^{40} \mathrm{Ar}-{ }^{39} \mathrm{Ar}$ ages broadly coincident $(90 \pm 10 \mathrm{Ma})$ with obduction processes in the region, as well as with other blueschist exposures known from Western Turkey to the Himalayas (Fig. 1b; Agard et al, 2006; Monié \& Agard, 2009). Their exhumation was therefore interpreted as the result of a regional-scale ( $\sim 3000 \mathrm{~km}$ along strike) modification of plate-slab coupling in the subduction zone below Eurasia during Late Cretaceous time.

\section{3.c. The Sanandaj-Sirjan Zone (SSZ)}

The SSZ (Stöcklin, 1968) represented an active Andean-like margin whose calc-alkaline magmatic activity progressively shifted northwards during most of the second half of the Mesozoic (Fig. 1b; Berberian \& King, 1981; Sengör, 1990; Agard et al. 2005). It already lies within the Iranian plateau in terms of elevation, yet follows the same NW-SE orographic trend as the ZFTB (Figs 1c, 4a). The SSZ forms the continental collage of Iran together with the Lut block and other blocks from Central Iran (see Section 3.e; e.g. Ricou, 1994) and extends from the Bitlis area in Turkey to the western end of Makran (Sengör et al. 1988; McCall \& Kidd, 1982), across the present-day transition zone from collision to subduction (Fig. 1c). The crustal root of the Zagros orogen in fact coincides with the SSZ (Snyder \& Barazangi, 1986), with a crustal thickness between 55 and $70 \mathrm{~km}$ (Paul et al. 2006, 2010).
As elsewhere in Iran, series of Infracambrian to Triassic rocks are found in the SSZ (Stöcklin, 1968), with only few basement outcrops (near Golpaygan and south of Mahabad; Alavi \& Mahdavi, 1994; Hassanzadeh et al. 2008). The SSZ mainly exposes metamorphosed cover series from Permian to Upper Cretaceous (Orbitolina limestone), with thick Permian (Golpaygan and Dorud-Azna regions) and Triassic rocks in places (June complex; Mohajjel, Fergusson \& Sahandi, 2003), notably where they are thrust along the MZT on top of the Crush Zone (Gidon et al. 1974). The Songor-Kangavar Triassic to Jurassic volcanic series or lateral equivalents (such as the Upper Triassic-Jurassic turbiditic succession of the Hamadan phyllite; J. Braud, unpub. Ph.D. thesis, Univ. ParisSud, 1987) are topped by a Neocomian unconformity, which seems slightly diachronous along strike (Thiele et al. 1968; J. Braud, unpub. Ph.D. thesis, Univ. ParisSud, 1987; Mohajjel \& Fergusson, 2000). Lowermost Cretaceous marine sediments are absent, contrary to the ZFTB (Fig. 3), and only limited alternating andesitic volcanic rocks, limestone and shales are found. These formations are in turn overlain by the extensive, slightly unconformable Barremian Orbitolina limestone. Eocene sediments are spatially restricted in the SSZ (Mian Kuh basin near Songor; J. Braud, unpub. Ph.D. thesis, Univ. Paris-Sud, 1987) and, unlike underlying formations, not affected by deformation. Continental or shallow marine Neogene deposits are represented by the Oligo-Miocene Lower Red, AquitanoBurdigalian Qom (equivalent to the ZFTB Asmari Fm) and Upper Red formations, respectively. Quaternary endoreic deposits finally filled in most of the SSZ valleys.

The metamorphosed and deformed SSZ is also characterized by the emplacement of subductionrelated, mainly Mesozoic calc-alkaline plutons and lavas (Figs 2a, 4a, 5b). The age compilation of recent radiometric datings (Fig. 5c) confirms that the SSZ is the locus of arc magmatism essentially during the Mesozoic (Berberian \& Berberian, 1981), but recent data showed local magmatic activity as young as Eocene in the NW SSZ (Mazhari et al. 2009b). There is also an apparent time migration from SE to NW (Agard et al. 2005; Fig. 2a) that is not accounted for at present. Note also the possible time clusters of magmatic activity (Fig. 5c; Late Jurassic: Ahmadi Khalaji et al. 2007; Fazlnia et al. 2007; Shahbazi et al. 2010; and Late Cretaceous), but more data is required to ascertain this. The timing of inception of subduction is debated in the literature, whether Late Triassic (which would coincide with the time of closure of the Palaeo-Tethys to the north) to Early Jurassic (Berberian \& King, 1981; Arvin et al. 2007) or Late Jurassic (Mohajjel, Fergusson \& Sahandi, 2003). Note, however, that Triassic magmatic rocks in Iran are almost completely restricted to the SSZ (Fig. 2b; Berberian \& Berberian, 1981), some showing a calc-alkaline signature, which could suggest that subduction had already begun by the Late Triassic (J. Omrani, unpub. data). 
Metamorphism is marked by mostly low-grade greenschist facies rocks, but reaches amphibolite facies near some plutons (near Hamadan and Azna; Agard et al. 2005; J. Omrani, unpub. Ph.D. thesis, Institut des Sciences de la Terre, Paris, 2008). The dominant regional schistosity, S2, is characterized by tight $\mathrm{S}$ - to $\mathrm{SW}$-vergent isoclinal folds affecting the Permian to Cretaceous formations to the north (Mohajjel \& Fergusson, 2000) and to the south of the SSZ (Sheikholeslami et al. 2003). Although seemingly related to intrusions, the age of this Andean-type metamorphism is not well constrained, with possibly a first stage during Late Jurassic time and a second one during Late Cretaceous time (J. Braud, unpub. Ph.D. thesis, Univ. Paris-Sud, 1987). Eclogites have also been locally reported from the SSZ (Davoudian et al. 2006, 2007), but are Triassic in age (Davoudian, pers. comm).

Late Cretaceous strike-slip movements were reported by several authors (Stöcklin, 1968; Alavi, 1994; Mohajjel \& Fergusson, 2000; Mohajjel, Fergusson \& Sahandi, 2003; Agard et al. 2005). The SSZ was nevertheless only thrust onto the Crush Zone from the Mid-Miocene onwards (Agard et al. 2005; Fig. 4b). Limited yet consistent apatite fission-track data (J. Omrani, unpub. Ph.D. thesis, Institut des Sciences de la Terre, Paris, 2008; Homke et al. 2010) cluster in the range $25-28 \mathrm{Ma}$ (Fig. 4a). These ages suggest that the SSZ, by contrast with the ZFTB, was significantly uplifted and eroded prior to Miocene time.

\section{3.d. The Urumieh-Dokhtar Magmatic Arc (UDMA)}

The UDMA (Schröder, 1944), situated between the SSZ and Central Iran, runs parallel to the Zagros and the SSZ (Figs 1c, 4a). It forms a topographic ridge separating the SSZ from Central Iran, and bears huge volcanosedimentary deposits, in places $>10 \mathrm{~km}$ thick (Dimitrijevic, 1973).

The UDMA hosts abundant Tertiary magmatism, dominantly of arc (Berberian \& Berberian, 1981; Berberian et al. 1982; Emami, 2000) or island-arc type (Shahabpour, 2005). Volumetrically, volcanic rocks were mostly produced during Eocene time (Farhoudi, 1978; Shahabpour, 2005), with the oldest ones dating back to Early Eocene time (Ypresian; c. 55-50 Ma; Emami, 2000). Note, however, as already emphasized by Omrani et al. (2008) that the Eocene magmatic activity was not restricted to the UDMA (Fig. 2a, d). Intrusive rocks, by contrast, are dominantly Oligo-Miocene (Berberian \& Berberian, 1981), but more recent datings and maps are probably needed to strengthen this. The UDMA was interpreted as subduction-related (with different locations for the suture zone: Berberian \& Berberian, 1981; Alavi, 1994) or rift-derived (Amidi, Emami \& Michel, 1984). More recently, Omrani et al. (2008) showed that the UDMA rocks derive from a supra-subduction mantle source, with comparable multielement patterns to those from the SSZ (Fig. 5b).

Radiometric age constraints for the UDMA are rather poor, but NW to SE gradients can be identified from stratigraphic constraints on available geological maps: from 35 to $16 \mathrm{Ma}$ and from 24 to $12 \mathrm{Ma}$ to the NW and SE of the Doruneh fault, respectively. New age constraints, using zircon laser ablation inductively coupled plasma mass spectrometry (LA-ICP-MS) U$\mathrm{Pb}$ and whole-rock $\mathrm{Ar}-\mathrm{Ar}$ age data (Chiu et al. 2010; see also Fig. 7) confirm this trend, with a cessation of calc-alkaline magmatism in the UDMA in Late Oligocene time near Tabriz $(\sim 27 \mathrm{Ma})$, in Middle Miocene time in Esfahan $(\sim 16 \mathrm{Ma})$ and in Late Miocene time near Kerman $(\sim 7 \mathrm{Ma})$.

By contrast to normal calc-alkaline magmatism, which is found everywhere along the UDMA, restricted adakitic provinces are found from $\sim 10 \mathrm{Ma}$ onwards in the extreme NW of Iran (Jahangiri, 2007) and in the central part of the Zagros orogen, around Anar (Omrani et al. 2008; Figs 4a, 5d). Age constraints were based on cross-cutting relationships (across the Upper Red Fm), and recent radiometric constraints indeed range between 10 and $1 \mathrm{Ma}$ (Chiu et al. 2010). Omrani et al. (2008, 2009), based on the type and location of high-silica adakites (HSA, Fig. 5e; Martin et al. 2005), related this adakitic magmatism to slab breakoff below the south-central part of the Zagros. This is also suggested by tomographic images (Fig. 6), which show that the Neo-Tethyan slab is detached below the central Anar region and possibly further to the NW (Hafkenscheid, Wortel \& Spakman, 2006).

The most recent magmatic activity is found in the SE part or in the extreme NW of the UDMA (near the Turkish border; Jahangiri, 2007; Kheirkhah, Allen \& Emami, 2009). Alkaline, post-collisional lavas (as in Turkey, e.g. Pearce et al. 1990; Keskin, Pearce \& Mitchell, 1998; or as reported elsewhere in Eurasia, e.g. Chung et al. 2005) are found in volumetrically large amounts in the latter area only, but small outcrops of (presumably Quaternary) alkaline basalt are found in many places, mainly along fault zones.

\section{3.e. Central Iran and the Iranian plateau}

Central Iran comprises metamorphic successions and plutonic suites (e.g. Chapedony and Posht-e-Badam metamorphic complexes: Haghipour, 1974; Nadimi, 2007; Precambrian plutonism: Berberian \& Berberian, 1981) and overlying Jurassic-Cretaceous and subordinate Palaeogene cover formations (see also Fig. 3).

There has been ongoing debate on whether Central Iran represents a central median mass (see Stöcklin, 1968 for an historical perspective) or corresponds to a mosaic of microblocks (e.g. Lut, Tabas, Yazd and Anarak blocks). Despite complexities inherited from pre-Pan-African times (e.g. the N-S trend in the Tabas area, or the Lut 'block', which was a Precambrian basement horst; Stöcklin, 1968; Nadimi, 2007 and references therein) or Palaeo-Tethys closure (Bagheri \& Stampfli, 2008), Central Iran, the UDMA and SSZ can together be considered to represent the upper plate domain during most of the recent convergence history leading to the Zagros orogeny. The main 

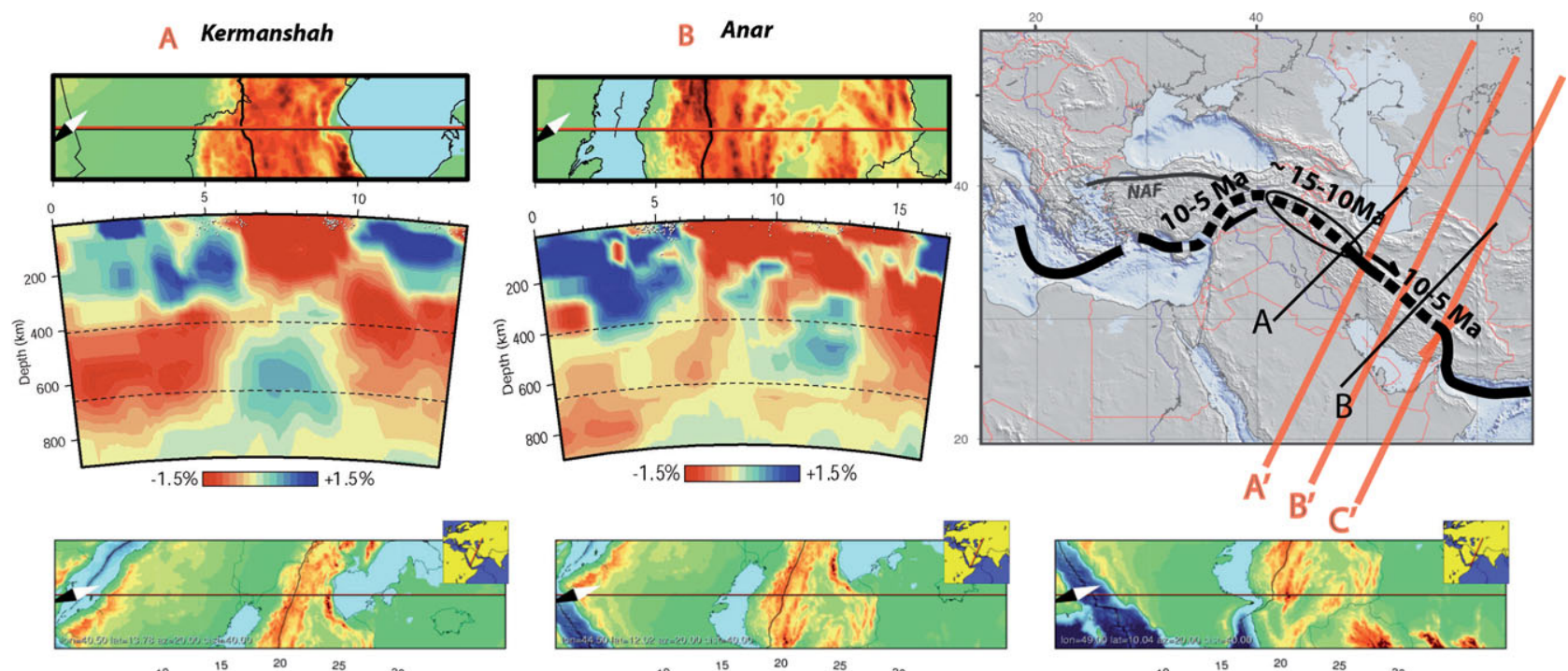

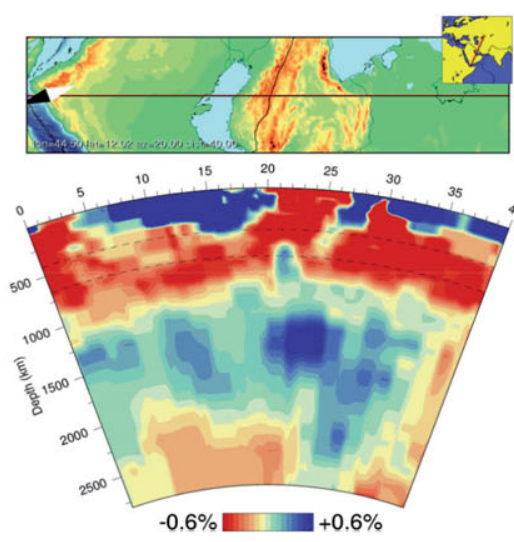

$\mathrm{B}^{\prime}$

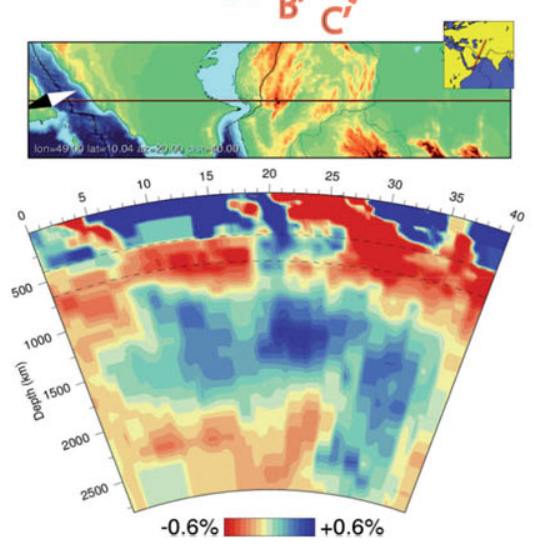

$C^{\prime}$

Figure 6. (Colour online) Tomographic sections across the Zagros orogen (location of transects on map; W. Spakman, unpub. data; for acquisition details see Hafkenscheid, Wortel \& Spakman, 2006 for example). Tomographic sections A and B constrain our present-day lithospheric-scale 1D reconstruction of the Kermanshah and Anar transects (Fig. 9) and their evolution through time (Figs 10, 11). Note that both A and B sections point to a detached slab below the Zagros, although to a lesser extent for section A. Sections $\mathrm{A}^{\prime}-\mathrm{C}^{\prime}$, though less precise in terms of velocity anomalies, are used to further suggest that the remnant Neo-Tethyan slab could be somewhat more continuous below the Kermanshah region (NW Zagros) than below the Central Zagros. We interpret this as a more recent slab break-off below the NW Zagros (whether the slab may even be still attached in places, however, cannot be assessed confidently). More extensive slab break-off below the Central Zagros is consistent with the finding of Upper Miocene adakites in the Central Zagros only (Fig. 5d, e) and a northward younging trend for these adakites (from $\sim 9$ to $1 \mathrm{Ma}$; Chiu et al. 2010). Ages on map: age constraints for recent slab break-off in the Alpine convergence zone (between E Turkey and Makran). NAF - North Anatolian Fault.

volcanic activity, as for the UDMA, took place during Eocene time. A stage of extensional tectonic activity, marked by distributed extension and the formation of core-complexes, took place during mid-Eocene time (c. $45 \mathrm{Ma}$; Verdel et al.2007) and pre-dates later, syn- to post-Oligocene SW-NE shortening (Kargaranbafghi, Neubauer \& Genser, 2010).

Most importantly, Central Iran is cross-cut by several ophiolitic domains (Nain-Baft, Sabzevar, Sistan; Fig. 1c) interpreted as minor oceanic seaways showing discontinuous oceanic crust emplacement (e.g. Baroz et al. 1984; Arvin \& Robinson, 1994). These domains correspond to the Upper Cretaceous to Paleocene radiolarite and ophiolite 'coloured melange' of Gansser (1960) and to the inner Mesozoic oceans of McCall (1997).

Both the back-arc Nain-Baft (Arvin \& Robinson, 1994) and the Sabzevar oceanic domains are thought to have opened during Late Cretaceous time and closed during Paleocene time (c. 95-60 Ma; Davoudzadeh, 1972; Baroz et al. 1984; Sengör et al. 1988; Arvin \& Robinson, 1994; Stampfli \& Borel, 2002; Shojaat et al.
2003). Few radiometric age constraints are available for the Nain-Baft (93 Ma, K-Ar dating on hornblende; Shafaii Moghadam et al. 2009) and Sabzevar ophiolites (86-87 Ma; Baroz et al. 1984).

The Nain-Baft ophiolite is not found north of Nain and the Doruneh fault, which suggests that the SSZ was only partially separated from Central Iran. The suggestion that the Nain-Baft could be equivalent to the Neyriz and Kermanshah ophiolites (i.e. considering them as tectonic allochthons from the Nain-Baft ophiolite across the SSZ) was made by Alavi (1994) and more recently by Shafaii Moghadam, Stern \& Rahgoshay (2010). The following major objections need to be recalled, however: (1) contrary to the outer ophiolites, which have equivalents in Turkey, there is no continuation to the north of the Nain-Baft domain, (2) blueschists marking the suture are only found to the SW of the SSZ, and (3) the SSZ does not correspond to fore-arc material.

The palaeogeography of the Sabzevar ophiolitic domain is uncertain, with authors connecting it to Nain-Baft (Stampfli \& Borel, 2004; Bagheri \& 
Stampfli, 2008) or to Sistan (Barrier \& Vrielynck, 2008; Saccani et al. 2010), making it an independent small oceanic domain, or connecting it to both (see Saccani et al. 2010, fig. 12). High-pressure granulites in one of the Sabzevar sub-units, with 106 Ma zircon overgrowths, could also testify to early subduction events in the region (Rossetti et al. 2009).

The Sistan region, finally, forms a $>700 \mathrm{~km}$ long, N-S belt sandwiched between Central Iran and Afghanistan or, more generally, between the Zagros and Himalayan orogens. The Sistan oceanic domain once represented a back-arc domain or a branch of the Neo-Tethys (Tirrul et al. 1983; hence breaking through Eurasia like the Alpine Liguro-Piemontese ocean; Agard \& Lemoine, 2005), and was later closed during Paleocene-Eocene time through an E-dipping subduction. Aptian-Albian radiolarites were reported by Babazadeh \& de Wever (2004), suggesting oceanic lithosphere production between 110 and $50 \mathrm{Ma}$ and a somewhat earlier (Early Cretaceous?) rifting than for the Nain-Baft and Sabzevar domains. Subduction is thought to have started between the TuronianMaastrichtian (Saccani et al. 2010) and led to the formation of some highly deformed blueschist and eclogite-bearing melanges (Fotoohi Rad et al. 2005). Note that exhumation of HP rocks took place at the same time as for the Zagros blueschists (c. $86 \mathrm{Ma}$ by $\mathrm{Rb}-\mathrm{Sr}$ dating on phengite: Bröcker, Fotoohi Rad $\&$ Theunisson, 2010; these authors dismissed, on the suspicion of excess argon, the earlier $\mathrm{Ar}-\mathrm{Ar}$ ages of Fotoohi Rad, Droop \& Burgess, 2009, mainly in the range 124-116 Ma). After closure, the Sistan region was affected by intense Eo-Oligocene to Early Miocene magmatic activity (Camp \& Griffis, 1982; Fig. 2d, e). These authors (as well as Sadeghian et al. 2005) related the Upper Eocene-Lower Oligocene calcalkaline granitic batholiths to the anatexis of marine sediments, and the mainly Oligocene alkaline volcanics and minor intrusions to major transcurrent faults. As for other parts of Iran, late alkaline activity is found along some major dextral strike-slip faults from Late Miocene time onwards (Fig. 2; i.e. the Nayband and Ney faults; Walker et al. 2009).

\section{3.f. Far-field deformation areas: Alborz, Kopet Dagh}

These regions are only briefly described here (see publications below and references therein for details). The Alborz Mountains (Fig. 1c) represent a good example of an intracontinental belt, with a stretched continental domain inverted during Late Triassic time (Zanchi et al. 2006) and the Tertiary (e.g. Guest et al. 2006; Ritz et al. 2006), as a result of both Palaeo-Tethyan and NeoTethyan closures. The Alborz is thus an integral part of the Arabia-Eurasia collision zone, and accommodates present-day convergence (Fig. 1d) through orogennormal shortening and lateral escape (left-lateral escape of the South Caspian basin in the west, and more complex deformation partitioning, including rightlateral movements, to the east; Hollingsworth et al.
2008). The adjacent Kopet Dagh fold-and-thrust belt (Fig. 1d), which developed at the expense of a thick Jurassic to Oligocene trough ( $\sim 6 \mathrm{~km}$ of sediments, i.e. more than in the Zagros for that period), also reworks the Palaeo-Tethys suture zone. Across-range shortening estimates for the Tertiary deformation are of the order of 30-35 km for both areas (Allen et al. 2003; Guest et al. 2006). Convergence also likely resulted, since 2-5 Ma, in the subduction of the South Caspian basin below the Apsheron-Balkhan sill to the north and the Talesh region to the west (Jackson et al. 2002; Masson et al. 2006; Hollingsworth et al. 2008).

Differences between the Alborz region and Central Iran and the SSZ include thicker (up to $5 \mathrm{~km}$ !) Middle Jurassic series and, unlike the SSZ, the lack of an Upper Jurassic-Lower Cretaceous unconformity (only a slight period of emersion is reported). There is evidence for a Late Cretaceous-Paleocene compression (Barrier \& Vrielynck, 2008). Minor Cretaceous magmatism is reported in the Alborz, but the main magmatic activity is broadly coincident with that of the UDMA and dated between 45 and $36 \mathrm{Ma}$ (Ballato et al. 2010). It is exemplified by the Eocene Karaj Formation, making up to $4 \mathrm{~km}$ thick calc-alkaline tuffs, and generally thought to mark (possibly back-arc) extension. The Damavand, by contrast, stands out as an isolated alkaline Quaternary volcano, possibly associated with deep lithospheric delamination (i.e. partial removal of the lithospheric mantle; Mirnejad et al. 2010).

\section{Major events recorded during convergence}

The above description points to a relatively simple geodynamic evolution, which can be envisioned, as a first approximation (see also Agard et al. 2005), through the following stages: (a) rifting of the NeoTethys during Early to Mid-Permian time (Dercourt et al. 1986; Sengör et al. 1988; Stampfli, Marcoux \& Braud, 1991) and Late Triassic collage of Iran to Eurasia following Palaeo-Tethys closure (Sengör, 1990; Saidi, Brunet \& Ricou, 1997; Stampfli \& Borel, 2002); (b) subduction of the Neo-Tethys below Eurasia, probably from Late Triassic or Early Jurassic time onwards (as testified by arc magmatism in the SSZ; Figs 2b, 5c); (c) obduction of the Neo-Tethyan lithosphere onto Arabia during Late Cretaceous time, sealed by uppermost Cretaceous deposits in Oman and Neyriz, and feeding detrital basins in the Arabian foreland (Maastrichtian Muti Fm in Oman, Paleocene Amiran flysch in NW Central Zagros). The high-pressure, lowtemperature continental rocks found below the eastern parts of the Oman ophiolite (Saih Hatat; Goffé et al. 1988) are nevertheless lacking in Iran; (d) changes in arc magmatism during Eocene time, with a major shift from the SSZ to the UDMA, and with extensive magmatism affecting much of Iran (Fig. 2a); (e) collision and progressive build-up of the Zagros orogen from Oligocene time onwards.

In detail, however, Arabia-Eurasia convergence across the Zagros is more complex. In order to single out major events and important time correlations, 


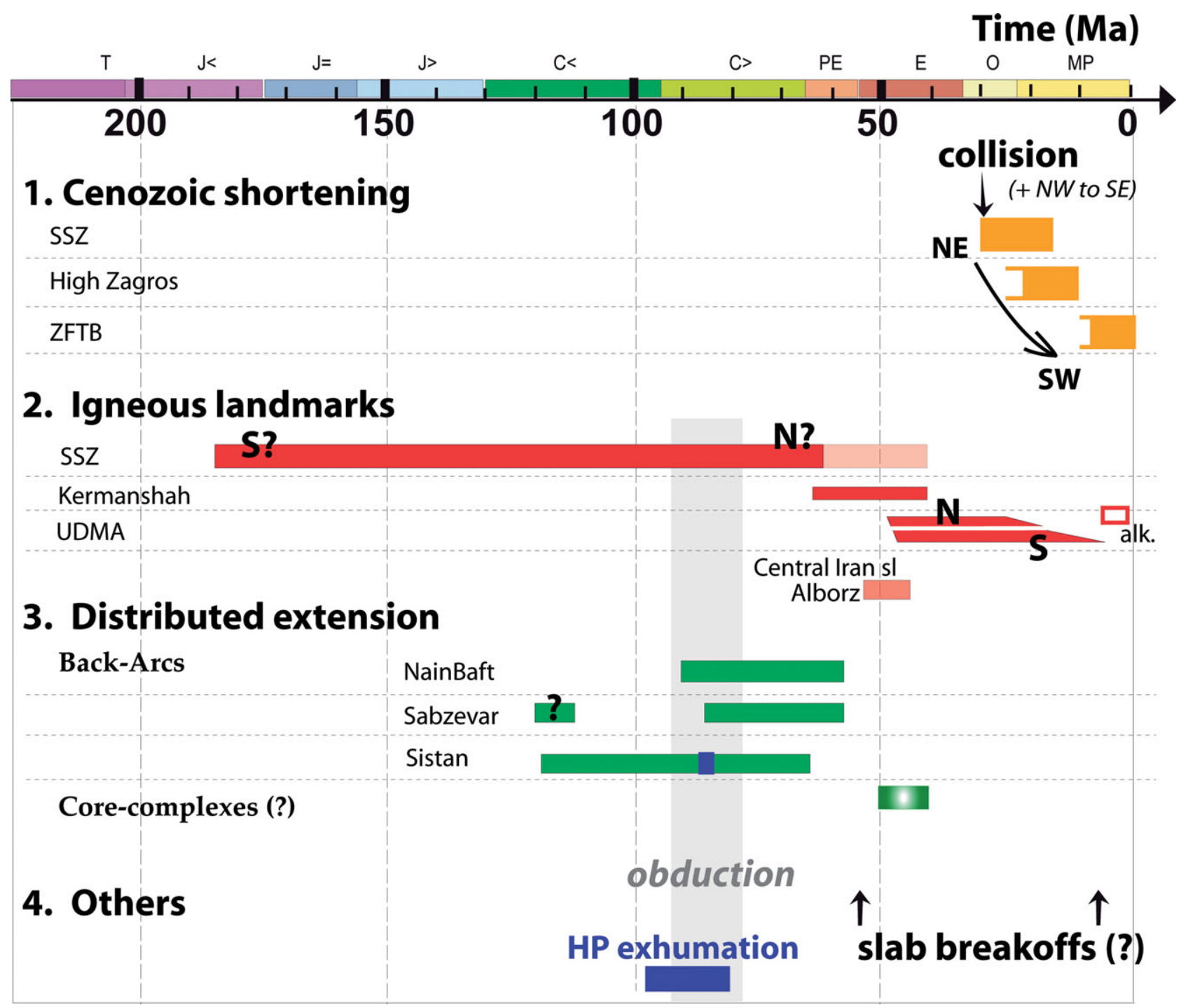

Figure 7. (Colour online) Three main types of tectonomagmatic landmarks are given here to single out major events and important time correlations: collision-related, igneous and extension-related landmarks, respectively, together with other constraints from ophiolites, high-pressure rocks (HP) and possible slab break-off events. See text for details (Section 4).

Figure 7 gives an overview of three major tectonomagmatic landmarks (together with constraints from ophiolites, HP rocks and possible slab break-off events discussed later), that need to be accounted for:

(1) Collision-related deformation: (i) The start of collision is bracketed within the latest Eocene to Oligocene period (Jolivet \& Faccenna, 2000; Agard et al. 2005; Ballato et al. 2010; Section 3.b), but the extent of diachronism along strike is yet unknown. Shortening estimates yield $70-110 \mathrm{~km}$ of shortening across the Zagros orogen, from the ZFTB to the SSZ. This amount of shortening over the last $20 \mathrm{Ma}$ (i.e. 3.5 to $5.5 \mathrm{~mm} \mathrm{yr}^{-1}$ ) is comparable to the one deduced from GPS measurements $\left(\sim 4-7 \mathrm{~mm} \mathrm{yr}^{-1}\right.$; Vernant et al. 2004). Deformation migrated outwards since the start of collision (Fig. 7).

(ii) The Mio-Pliocene to Quaternary evolution of the ZFTB ( $\sim 10$ Ma to present) comprises the uplift of the High Zagros (Gavillot et al. 2010), the migration of deformation to the SFB witnessed by growth strata in the Agha Jari Fm (McQuarrie, 2004; Mouthereau et al. 2007; Khadivi et al. 2010), a possibly greater implication of thick-skin tectonics from the Pliocene onwards (Molinaro et al. 2005) and a broadening of the orogenic belt (Allen, Jackson \& Walker, 2004).

(2) Magmatic evolution of the upper plate: (i) Any reconstruction should account for the magmatic shift from the SSZ to the UDMA (Fig. 2a), for their similar mantle source (Fig. 5b), as well as for widespread magmatism throughout Iran during Eocene time (Fig. 2a, d).

(ii) The Paleocene to Early Eocene magmatic activity in the Crush Zone (ETMD; Figs 4a, 5a) is broadly coincident with the temporal shift of magmatism from the SSZ to the UDMA (Fig. 7), and with a slowing down of convergence velocities (Fig. 8a).

(iii) Mio-Pliocene adakites form locally along the UDMA (Jahangiri, 2007; Omrani et al. 2008). Although there is widespread Quaternary alkaline magmatism, particularly along fault zones (e.g. Walker et al. 2009), extensive, recent post-collisional magmatism is only found in the northernmost part of the Zagros 

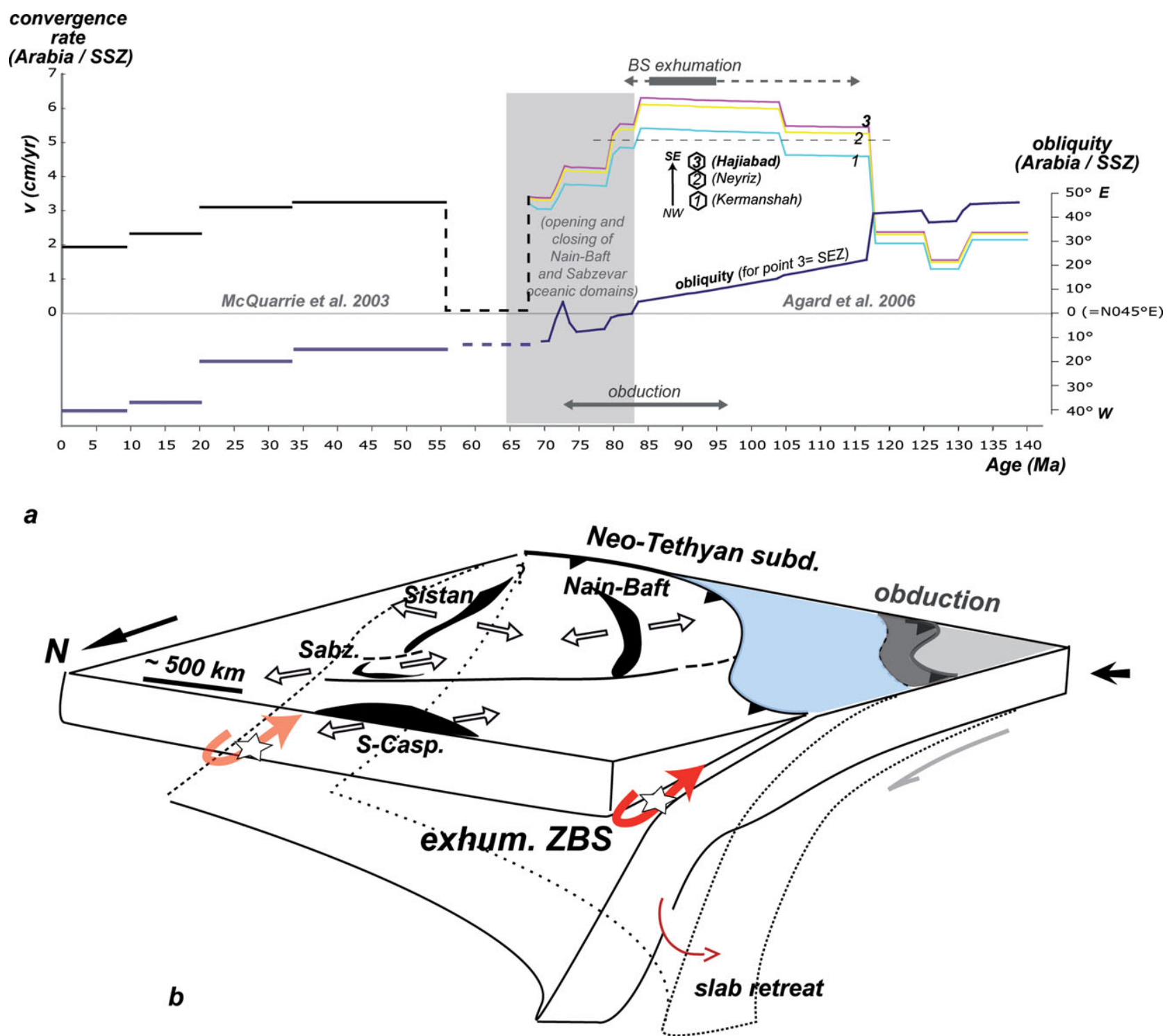

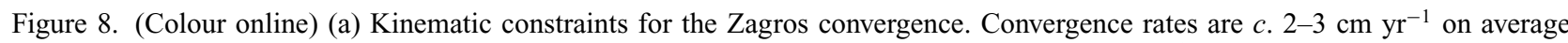
except for two noticeable periods: (1) a fast convergence period in the Late Cretaceous $\left(5-6 \mathrm{~cm} \mathrm{yr}^{-1} ; 118-80 \mathrm{Ma}\right.$; it coincides, in the region, with obduction and blueschist exhumation); (2) a very slow convergence period in the Paleocene (see also Dewey et al. 1989 and Rosenbaum, Lister \& Duboz, 2002). (b) Outline of the specific constraints provided by the almost coincident onset of regional-scale back-arc opening (see Section 3.e), blueschist (BS) exhumation along the Neo-Tethyan subduction zone (red arrows) and obduction onto Arabia following the $c .115$ Ma kinematic reorganization (a). Situation drawn at $c$. 90-85 Ma. Stretched, partly oceanic basins formed in the upper plate, from north to south: South Caspian (S-Casp.), Sabzevar (Sabz.), Sistan and Nain-Baft seaways.

orogen (Kheirkhah, Allen \& Emami, 2009; Chiu et al. 2010), close to Turkey (where it is well documented; e.g. Keskin, Pearce \& Mitchell, 1998).

(3) Evidence for distributed extension and links with ophiolite remnants: (i) There is evidence for the formation of core-complexes in Central Iran during Middle Eocene time (Verdel et al. 2007) and of an extensional basin in the Alborz (Vincent et al. 2005; Guest et al. 2006; Ballato et al. 2010).

(ii) A number of essentially non-metamorphic ophiolitic remnants (Nain-Baft, Sabzevar, Sistan) are found in the upper plate and interpreted as small backarc domains formed during Middle-Late Cretaceous time. Their formation coincides with regional-scale kinematic changes, blueschist exhumation and modifications of plate-slab coupling processes (Agard et al.
2006; Monié \& Agard, 2009; see Section 5.a and Figs $1 b, 8 b)$.

(iii) Obduction-related, Upper Cretaceous ophiolite remnants along the MZT (Kermanshah and Neyriz) differ in ophiolite type and in age. Despite an almost instantaneous regional start of obduction, as suggested by the dating of metamorphic soles (at $c$. 95 Ma; Hacker, Mosenfelder \& Gnos, 1996; Agard et al. 2007), final ophiolite emplacement onto Arabia youngs from Oman to Neyriz and Kermanshah, from Santonian (Searle \& Cox, 1999; Agard et al. 2010) to Maastrichtian (J. Braud, unpub. Ph.D. thesis, Univ. Paris-Sud, 1987; Homke et al. 2009), respectively. The Peri-Arabic obduction is thus not as cylindrical as earlier postulated (Ricou, 1971) and in fact, a significant part (if not all) of what is regarded as the 


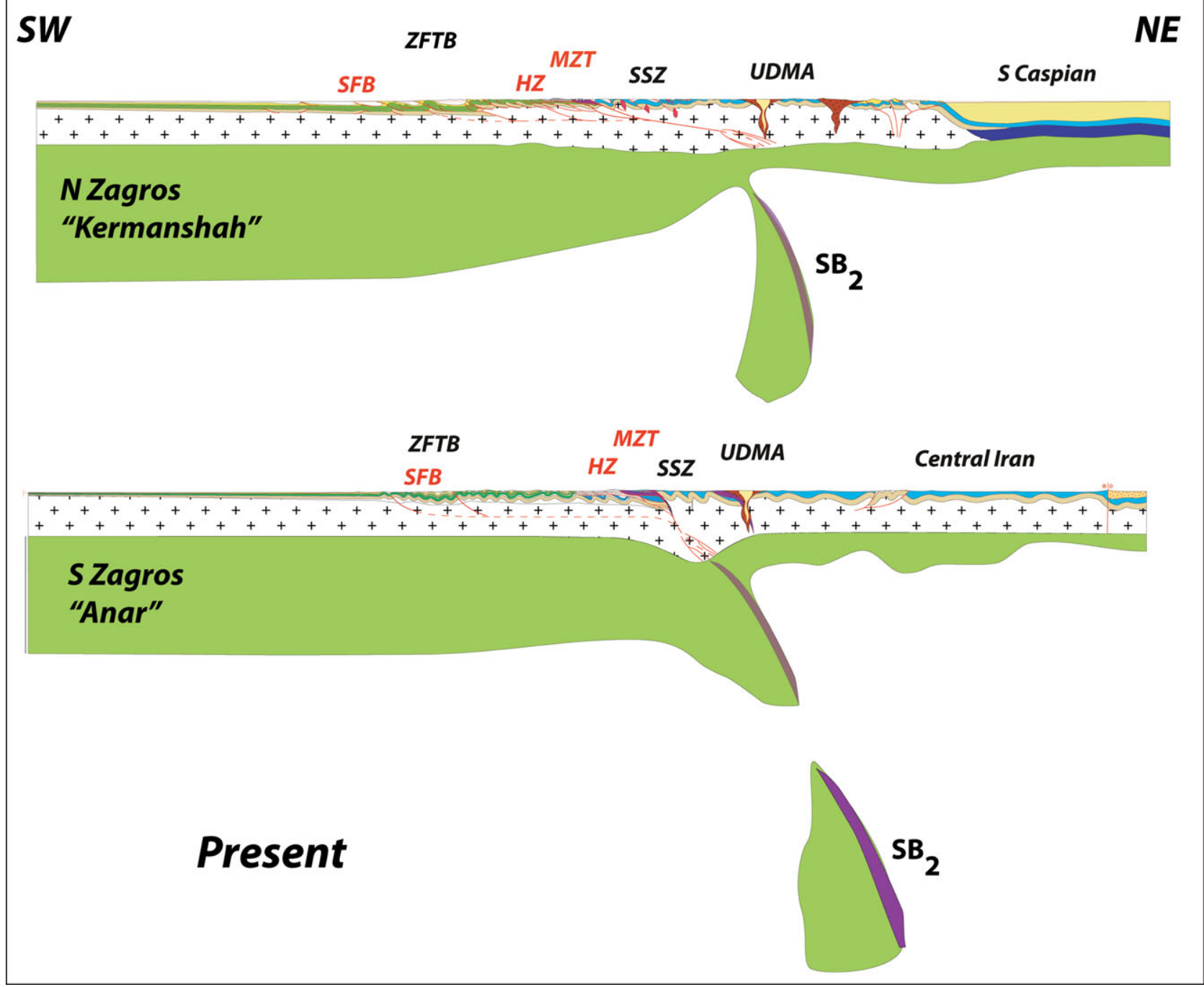

Figure 9. (Colour online) Present-day lithospheric-scale cross-sections built from tomographic constraints (sections A-B, Fig. 6) and crustal constraints (see text, Section 5). Abbreviations as for Figure 10.

Kermanshah ophiolite is only the sole of the ETMD (Fig. 4b).

\section{Lithospheric-scale reconstruction of Zagros geodynamics}

In the following Sections we attempt to reconstruct the evolution of the Zagros orogen along two cross-sections at the scale of the lithosphere (Fig. 9). The northern section (hereafter named 'Kermanshah') crosses the whole orogen from the foreland, on the Arabian plate, to the Caspian Sea (Fig. 1c). The second section ('Anar') runs from Arabia to Central Iran, across the Deshir and Anar faults (Fig. 1c). The present-day sections were established using all available geological (see previous Sections), kinematic and geophysical information, as explained in the next Sections.

\section{5.a. Geodynamic and geophysical constraints}

\section{5.a.1. Key geophysical constraints on present-day structures}

The present-day lithospheric and mantle structure below Iran shown in Figure 9 was built from the tomographic sections presented in Figure 6. The large volumes of positive anomalies are interpreted as the signatures of cold anomalies and used to trace the subduction zone beneath Central Iran. Although the resolution of these images is insufficient to show the real shape of the slab at depth, they can be used to see whether a slab is present, whether it is broken or continuous, and to obtain crude estimates of the subducted amounts of lithospheric material (see Hafkensheid, Wortel \& Spakman, 2006).

For Moho depths across the Zagros and Alborz we used the data of Paul et al. (2006, 2010) and Radjaee et al. (2010), respectively. These recent results are consistent with earlier gravimetric constraints (Dehghani \& Makris, 1984; Snyder \& Barazangi, 1986; Alinaghi, Koulakov \& Thybo, 2007). Based on receiver functions, Moho depths are shown to vary from $45 \mathrm{~km}$ in the Arabian plate below the Zagros to a maximum of $55 \mathrm{~km}$ (in the N-Central Zagros, Kermanshah transect; Paul et al. 2010) or $70 \mathrm{~km}$ (in the S-Central Zagros, Anar transect; Paul et al. 2006), with an abrupt gradient below the SSZ in the latter case. Further north, it decreases again beneath the UDMA 
and the Iranian plateau to reach $42 \mathrm{~km}$ (Paul et al. 2006). Numerous studies point to a fairly thin subcontinental lithosphere below Central Iran (as shown by lower $\mathrm{P}$ and $\mathrm{S}$ waves and/or high attenuation of $\mathrm{Sn}$ waves; e.g. Hafkenscheid, Wortel \& Spakman, 2006; Kaviani et al. 2007; Hatzfeld \& Molnar, 2010), yet not completely delaminated (Paul et al. 2010; unlike for Turkey: Pearce et al. 1990; Keskin, 2003; Al-Lazki et al. 2004, with suggestions of asthenospheric melting at $<\sim 80 \mathrm{~km}$ depth; Kheirkhah, Allen \& Emami, 2009; Walker et al. 2009). By contrast, Priestley \& McKenzie (2006) pointed to a fairly thick lithospheric root $(\sim 200 \mathrm{~km})$ below the SSZ. One suggestion is that this may represent lithospheric mantle possibly ponded by convective removal of the sub-continental lithosphere (see discussion in Hatzfeld \& Molnar, 2010).

Below the Alborz range the Moho depth ranges between 46 and $58 \mathrm{~km}$ (Radjaee et al. 2010). Further to the NE, in the South Caspian basin, the Moho keeps a constant depth but the crust is more rigid (Jackson et al. 2002) with higher seismic velocities suggesting an oceanic basement overlain by a $>20 \mathrm{~km}$ thick sedimentary basin (Mangino \& Priestley, 1998; Brunet et al. 2003; Guest, Guest \& Axen, 2007).

\section{5.a.2. Constraints from kinematic reconstructions}

Convergence velocities and obliquity of the ArabianEurasian convergence provide the necessary kinematic boundary conditions for any model of Zagros geodynamics (Fig. 8a; Dewey et al. 1989; Dercourt et al. 2000; McQuarrie et al. 2003; Stampfli \& Borel, 2004; Rosenbaum, Lister \& Duboz, 2002; Agard et al. 2006; Barrier \& Vryelinck, 2008). It is still unclear, however, when ocean-floor spreading ceases in the Neo-Tethys and if and when there are ridge jumps (Whitechurch et al. 1984; Ricou, 1994).

Convergence rates are around $2-3 \mathrm{~cm} \mathrm{yr}^{-1}$ (Fig. 8a) except for during two noticeable periods: (1) The fast convergence rate in Late Cretaceous time $(5-6 \mathrm{~cm}$ $\left.\mathrm{yr}^{-1} ; 118-80 \mathrm{Ma}\right)$ coincides with the well-known quiet magnetic anomaly (Larson, 1991), the formation of a super plume below the South Pacific and a general acceleration of oceanic accretion worldwide (Cogné $\&$ Humler, 2004). The regional-scale Late Cretaceous obduction event also takes place during the second half of this period of rapid convergence (Fig. 8a). This acceleration of convergence is thought to have triggered obduction (Agard et al. 2007): acceleration would have increased the resistance of the asthenospheric mantle to the subducting Neo-Tethyan slab and transmitted compressional stresses across the lower plate until the formation of a new (and temporary) subduction zone on the southern side of the Neo-Tethys (thereby leading to obduction). The concomitant exhumation of blueschists, from Western Turkey to the Himalayas ( $~ 3000 \mathrm{~km}$ along strike; Figs 1b, 8a), is interpreted as the result of a regional-scale modification of plate-slab coupling in the subduction zone below Eurasia (Monié \& Agard, 2009). This major Aptian-Albian kinematic reorganization is also recorded in the sedimentation of the Mesozoic deep-sea carbonates from the southern margin of the Neo-Tethys (Robin et al. 2010). Figure 8b outlines the specific constraints provided by the almost coincident onset of regional-scale back-arc opening (see Section 3.e.), blueschist exhumation and obduction following the $c .115$ Ma kinematic reorganization.

(2) Another distinctive feature of the kinematic history is the very slow Paleocene convergence rate. Both Dewey et al. (1989) and Rosenbaum, Lister \& Duboz (2002) pointed out this low convergence velocity. Given the uncertainties on velocities it is quite possible that convergence even completely stopped during some $10-15 \mathrm{Ma}$ and resumed afterwards at a rate of $\sim 3 \mathrm{~cm} \mathrm{yr}^{-1}$ (McQuarrie et al. 2003). The convergence velocity then progressively decreased to reach the present $2 \mathrm{~cm} \mathrm{yr}^{-1}$. The obliquity of convergence, with respect to the strike of the Zagros orogen, shows a marked evolution too: obliquity sharply decreased after the $\sim 115$ Ma velocity change, then progressively changed from $\sim 115$ to $\sim 20 \mathrm{Ma}$ (yet staying within $20^{\circ}$ of the normal to the presentday strike of the Zagros orogen) before significantly changing again after $\sim 20 \mathrm{Ma}$.

\section{5.a.3. Balancing lithospheric-scale cross-sections}

For the palaeogeography and the width of Neo-Tethys Ocean through time we used the information from the Peri-Tethys Atlas (Dercourt et al. 2000) and additional constraints provided by Barrier \& Vrielynck (2008). The suture zone between Arabia and Eurasia is taken to lie along the MZT (i.e. to the south of the SSZ). For crustal shortening across the ZFTB (12$13 \mathrm{~km}$ of sediments decoupled from the basement and shortened about $60 \mathrm{~km}$ during the last $10 \mathrm{Ma}$; Fig. 4a), balanced cross-sections of Sherkati, Letouzey \& Frizon de Lamotte (2006) and of Mouthereau et al. (2007) were used for the Kermanshah and Anar transects, respectively. For the suture zone, we used those of Agard et al. (2005, 2006). In the Alborz, the total amount of (mainly post-Eocene) shortening is estimated to be approximately between 30 and $50 \mathrm{~km}$ (H. Nazari, unpub. Ph.D. thesis, Univ. Montpellier II, 2006; Guest et al. 2006). Little active thickening exists in the Central Iranian plateau (Allen, Jackson \& Walker, 2004; Morley et al. 2009), where deformation is mainly partitioned across the major strike-slip faults (see Section 2.b).

\section{5.b. Lithospheric-scale reconstructions across two transects}

We briefly describe the lithospheric evolution of the Zagros through seven stages for each transect (Fig. 10): Late Cretaceous (90 Ma), K-T boundary (65 Ma), Late Paleocene (60-55 Ma), Middle Eocene (45-40 Ma), Late Oligocene (25 Ma), Late Miocene $(10 \pm 5 \mathrm{Ma})$ and present day (enlarged in Fig. 9). For the sake of discussion, close-up views of the Kermanshah transect are also given in Figure 11. 


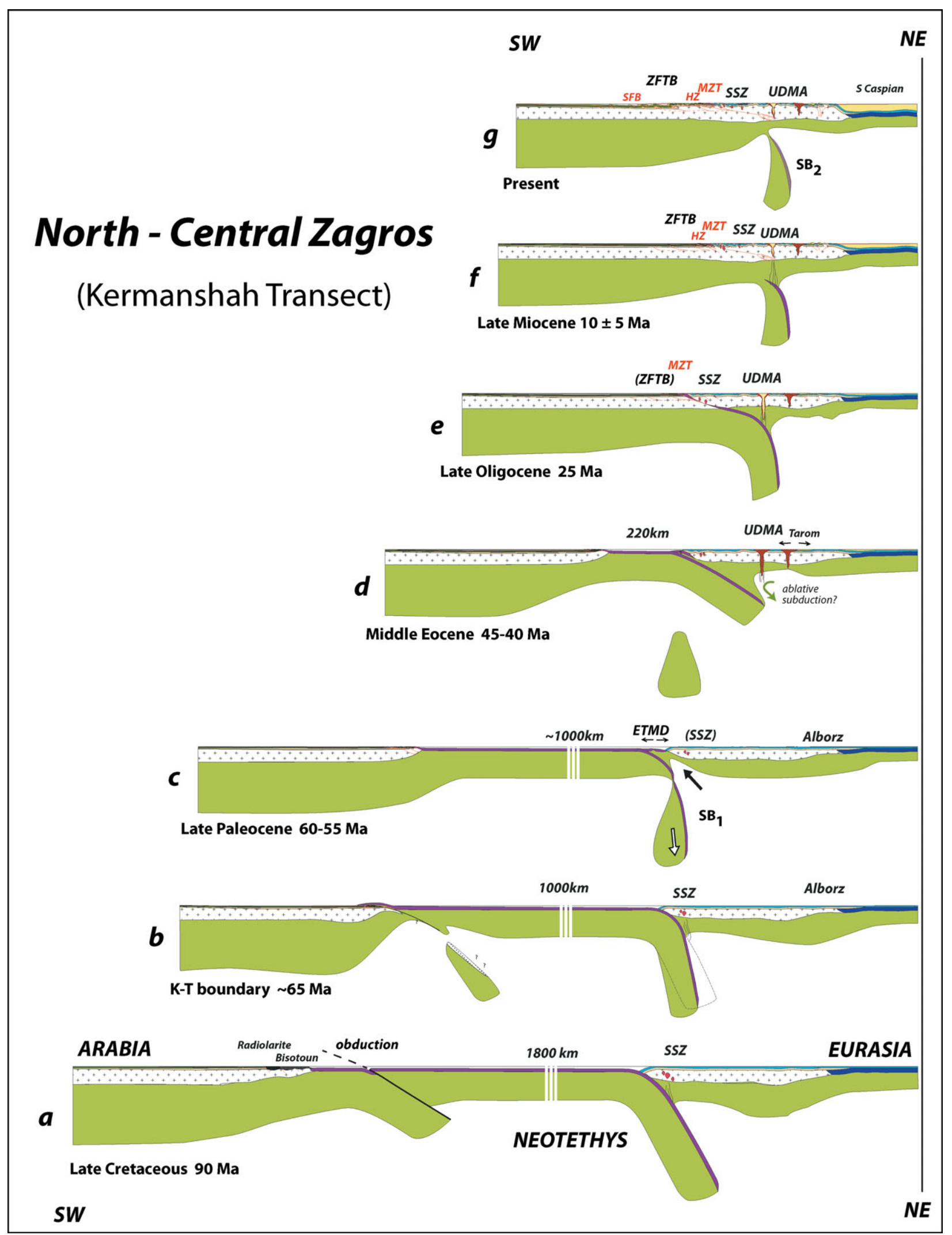

Figure 10. (Colour online) Lithospheric-scale cross-sections across two transects (Fig. 9; location in Fig. 1c). The northern section (a-g; termed 'Kermanshah') crosses the whole orogen from the foreland, on the Arabian plate, to the Caspian Sea. The second section ( $a^{\prime}-g^{\prime}$; 'Anar') runs from Arabia to Central Iran, across the Deshir and Anar faults. The present-day sections were established using all available geological, kinematic and geophysical data (see Section 5.a for details). We selected seven stages for each of the transects: Late Cretaceous (90 Ma), K-T boundary (65 Ma), Late Paleocene (60-55 Ma), Middle Eocene (45-40 Ma), Late Oligocene (25 Ma), Late Miocene (10 $\pm 5 \mathrm{Ma}$ ) and present-day cross-sections (enlarged in Fig. 9). For the sake of discussion, close-up views of the Kermanshah transect are also given in Figure 11. Detailed comments are given in Section 5.b of the text. Abbreviations: CC - core-complex; ETMD Early Tertiary Magmatic Domain; HZ - High Zagros Fault; MZT - Main Zagros Thrust; NB - Nain-Baft; SFB - Simply Folded Belt; SSZ - Sanandaj-Sirjan Zone; UDMA - Urumieh-Dokhtar Magmatic Arc; ZFTB - Zagros fold-and-thrust belt. 


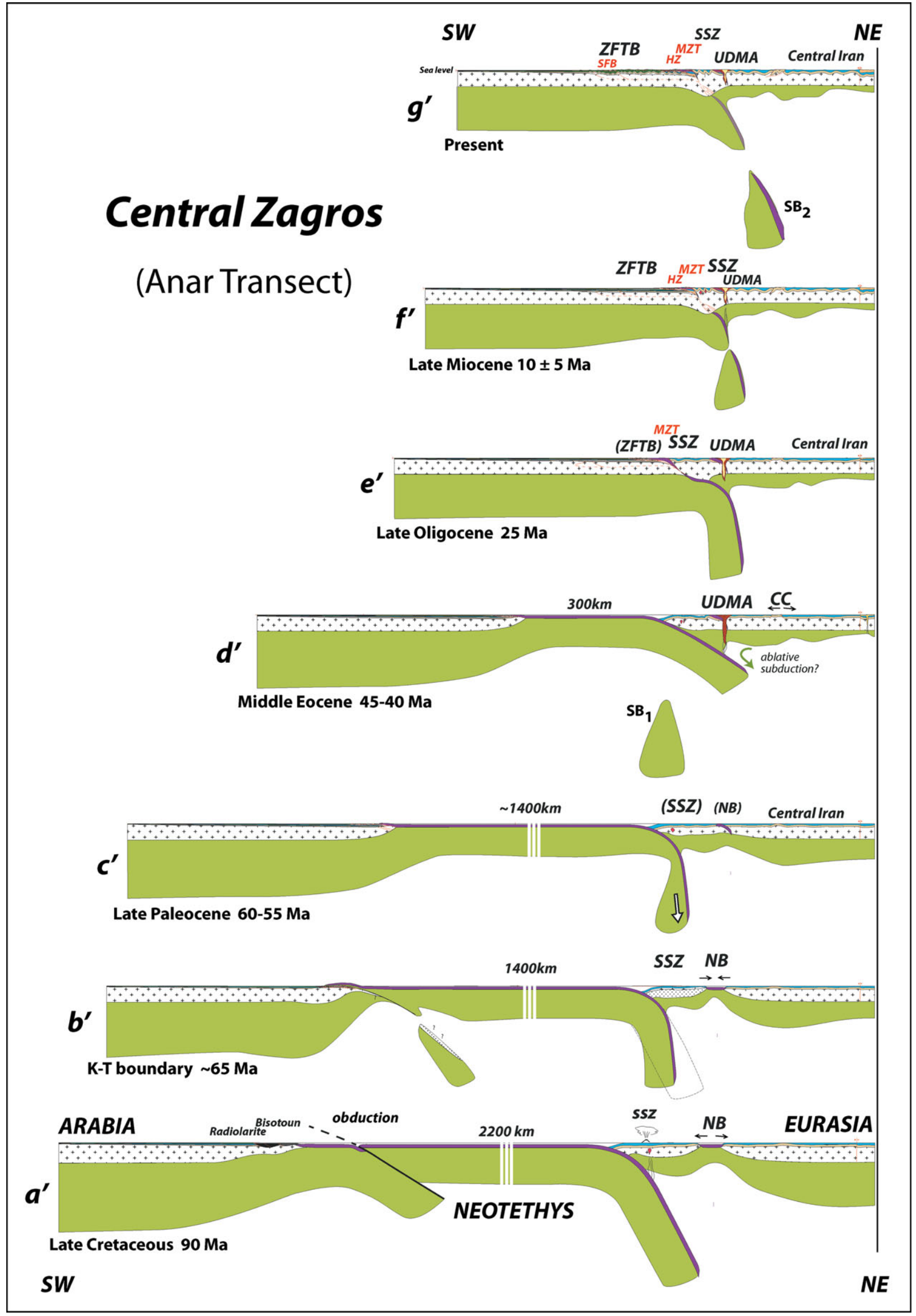

Figure 10. Continued. 


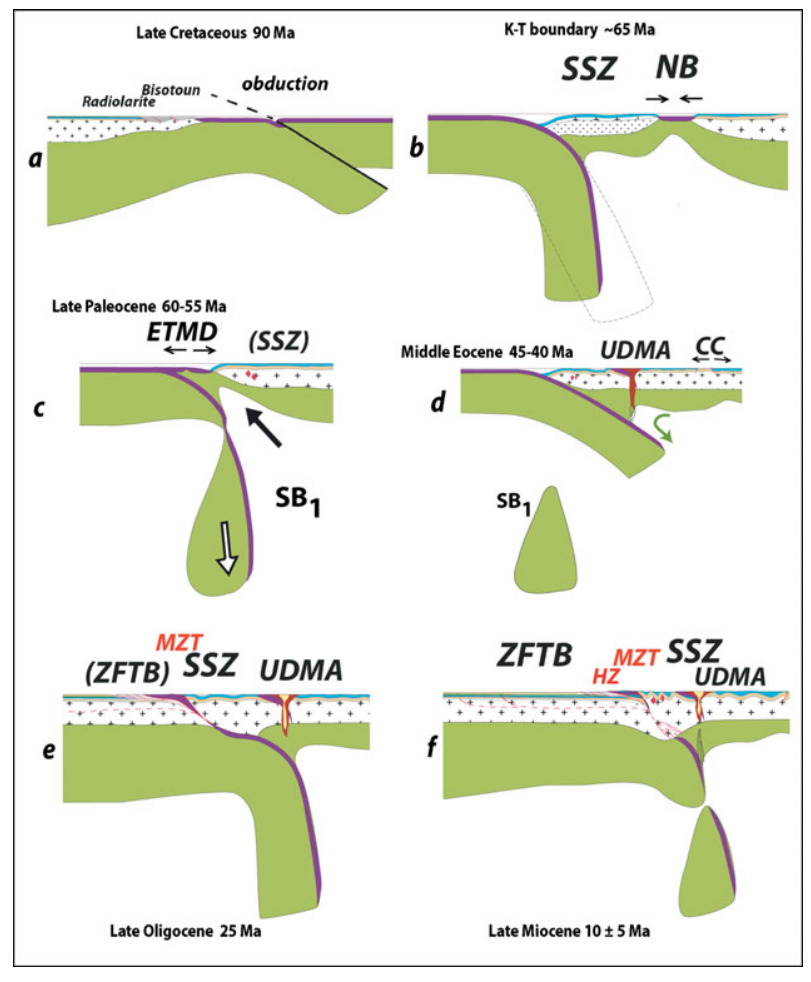

Figure 11. (Colour online) Close-up views of the lithosphericscale cross-sections presented in Figure 10, emphasizing some of the salient events of Zagros geodynamics (see discussion in Section 6.a). Abbreviations as for Figure 10.

\section{5.b.1. Late Cretaceous (90 Ma)}

This first stage (Fig. 10a, a') corresponds to the period of fast convergence, worldwide high production of oceanic lithosphere and high sea level (Cogné \& Humler, 2004). Subduction is active below the southern margin of Eurasia as indicated by arc magmatism (Figs 2a, 5c), and the width of the Tethys Ocean in this period reaches $\sim 1800 \mathrm{~km}$ and $2200 \mathrm{~km}$ for the Kermanshah and Anar sections, respectively. Regional-scale kinematic changes (fast convergence and reorientation; Fig. 8a) have led to the formation of metamorphic soles at $95 \mathrm{Ma}$ (e.g. Thuizat et al. 1981; Hacker, Mosenfelder \& Gnos, 1996) and to the inception of obduction processes near the southern margin of the Neo-Tethys, following intraoceanic thrusting (Agard et al. 2007). Across the Oman transect, the Arabian margin was subducted down to $\sim 70 \mathrm{~km}$ beneath the oceanic lithosphere (Searle \& Cox, 1999; Searle et al. 2004; Yamato et al. 2007). No traces of this deep history are found (or preserved) in Iran. These regional-scale kinematic changes are thought to be responsible for changes in the mechanical coupling in the northern subduction zone below Eurasia, possibly accompanied by slab retreat (Fig. 11b): blueschist units derived from oceanic material are exhumed in this specific time period only (Agard et al. 2006; Monié \& Agard, 2009) and small back-arc domains (such as the $\sim 90-60$ Ma Nain-Baft seaway; Arvin \& Robinson, 1994) form coevally in the upper plate, in the southern transect (Fig. 10a').

\section{5.b.2. $\mathrm{K}-\mathrm{T}$ boundary $(65 \mathrm{Ma})$}

The Neo-Tethys is still consumed beneath the SSZ (Fig. 10b, b'), yet the convergence velocity has already significantly decreased and this period is transitional to the Paleocene slow convergence (Fig. 8a). The cessation of volcanism at the end of this period in the SSZ is consistent with the fact that the slab had already migrated southwards. In the southern transect (Fig. 10b'), the Nain-Baft back-arc basin is progressively closing and will eventually disappear during the Paleocene (Davoudzadeh et al. 1972; Baroz et al. 1984; Arvin \& Robinson, 1994). Obduction is over on the southern margin of the Neo-Tethys Ocean. Near Kermanshah, the emplacement of oceanic lithosphere onto the continent through obduction has induced the deformation and uplift of the Neo-Tethyan ophiolite and of the Bisotun and radiolarite basins (Fig. 4b), the erosion of which now feeds the Amiran foreland basin (Homke et al. 2009). In the southern parts of the Zagros, near Neyriz, similar conditions prevailed (Ricou, 1971); obducted ophiolites resting on top of Coniacian units there are well preserved, however (unlike along the Kermanshah section; Fig. 4b), and are unconformably overlain by Maastrichtian limestones.

\section{5.b.3. Late Paleocene (60-55 Ma)}

This period is characterized by extremely slow convergence (Fig. 8a). The width of the Neo-Tethys during Paleocene time is thus not very different from that in the latest Cretaceous (Fig. 10c, c'). The ETMD (Crush Zone, Kermanshah region) attests to an intraoceanic arc located at the foot of the Eurasian margin until Early-Middle Eocene time (Figs 4b, 5a, 10c) and coincides with a time gap between the end of the SSZ main magmatic activity and the onset of volcanism in the UDMA (Fig. 7). The Late Cretaceous slab rollback probably accounts for the outwards migration of arc magmatism. In order to account for the ETMD magmatism itself, we propose a slab break-off and the melting of the metasomatized sub-continental lithosphere (with a subduction component) in response to heat provided by the asthenospheric window (Fig. 11c; Keskin, 2003; Benoit et al. 2002). Slab break-off is favoured by slow convergence, which enhances the relative downward traction of the relatively stagnant slab, and is common in the Neo-Tethys history (Wortel \& Spakman, 2000; Mahéo et al. 2002). As already noted, a marked geodynamic contrast nevertheless exists between the north and south Zagros transects (Fig. 10c, $c^{\prime}$ ): no Paleocene arc or Amiran flysch are found in the south, whereas the Nain-Baft basin (closed in Paleocene time) does not extend to the north (see Section 6.c).

\section{5.b.4. Middle Eocene (45-40 Ma)}

The ocean width decreased fast again from Eocene time onwards. After the Paleocene-Early Eocene slab break-off, the piece of oceanic lithosphere still attached 
to Arabia subducted with a lower dip, thus explaining the inwards volcanic arc migration towards the UDMA, where it remains until today (Figs 10d, d', 11d). The resumption of subduction-related, widespread calcalkaline magmatism in the UDMA (with a geochemical signature similar to the SSZ), together with the Paleocene slab break-off and its thermal consequences, could explain in part the widely distributed volcanism over much of Iran (Fig. 2a). Intense magmatic activity below the UDMA, together with the change of overall deformation patterns to extension (Fig. 7), may indeed have triggered magma ascent in the weak, deformable zones of the upper plate, in particular around largescale faults of Central Iran.

\section{5.b.5. Late Oligocene (25 Ma)}

At the end of Oligocene time, Arabia and Eurasia have collided and the oceanic crust has completely disappeared (Fig. 10e, e'). Final resorption of the oceanic domain took place after $35 \mathrm{Ma}$ and collision started before c. 25-23 Ma in the northern Zagros (Agard et al. 2005; Allen \& Armstrong, 2008; Homke et al. 2010). Incipient collision leads to the deformation of the SSZ and the Crush Zone, which are shortened by about $40 \mathrm{~km}$ (Agard et al. 2005). The last marine sediments (Lower Miocene Qom Fm) lie unconformably on both the Crush Zone nappe stack and the SSZ (Fig. 4b). The SSZ was actually largely shortened prior to the Qom sedimentation, before deformation propagated to the SW. Continental collision is first accommodated by subduction of the Arabian continent beneath the SSZ; this accounts for the disappearance of the distal part of the Arabian margin (Molinaro et al. 2005; Mouthereau et al. 2007) and for crustal thickening below the SSZ (Paul et al. 2006, 2010). Significant exhumation takes place in the SSZ during the first stages of collision (Fig. 4a; fissiontrack data at 28-25 Ma; J. Omrani, unpub. Ph.D. thesis, Institut des Sciences de la Terre, Paris, 2008; Homke et al. 2010), and volcanism is still active in the UDMA, but much less so than during Eocene time (Fig. 2e).

\section{5.b.6. Late Miocene $(10 \pm 5 \mathrm{Ma})$}

The Miocene period (Fig. 10f, $\mathrm{f}^{\prime}$ ) is a prelude to the present situation. The deformation has decreased in the SSZ and the Crush Zone and started to propagate towards the external zones of the Zagros. A rough balance of shortening suggests that, from 15 to 7-8 Ma, the external zone was shortened by about $10 \mathrm{~km}$ while the SSZ and the Crush Zone shortened by some $30 \mathrm{~km}$. A noticeable change in volcanism happens in the southern segment of the UDMA with the formation of adakites in the Anar region (Figs 4a, 5e). These adakites correspond to slab melting as a result of a second slab break-off (Omrani et al. 2008). Tomographic images (Fig. 6) indicate that the slab is effectively detached below Central Iran in the Anar region, possibly to a greater extent than in the north along the Kermanshah transect. Recent numerical models suggest a delay time of 10 to $20 \mathrm{Ma}$ for slab break-off after the start of collision (Van Hunen \& Allen, 2011), which would be consistent with the timing of this break-off at $10 \pm$ $5 \mathrm{Ma}$ (Molinaro, Zeyen \& Laurencin, 2005; Omrani et al. 2008).

\section{5.b.7. Present}

The present-day cross-section is recalled here for comparison (Fig. 10g, g'). Shortening has largely stopped in the SSZ and the Crush Zone since 7-8 Ma and mainly occurs in the ZFTB, which has shortened by about $60 \mathrm{~km}$ since. Adakitic magmatism continued up to Plio-Quaternary time along the Anar segment (Omrani et al. 2008; Chiu et al. 2010), while in the other parts of UDMA a normal calk-alkaline volcanism occurred. The underthrusting of Arabian crust, which started with the onset of collision during Oligocene time, led to thickening of the crust beneath the SSZ to a maximum of $70 \mathrm{~km}$ (Paul et al. 2006, 2010).

\section{Discussion}

\section{6.a. Geodynamics of Arabia-Eurasia convergence across the Zagros}

These lithospheric-scale reconstructions account for most of the key events outlined in Section 4 (see also Fig. 7) and allow us to highlight three critical time periods:

(1) Mid to Late Cretaceous (115-85 Ma; Fig. 10a-b/ $\left.\mathrm{a}^{\prime}-\mathrm{b}^{\prime}\right)$ : this period comprises back-arc basin formation in the upper Eurasian plate, with small oceanic domains cutting across Central Iran (Nain-Baft, Sabzevar, Sistan), blueschist exhumation along the northern NeoTethyan subduction zone and obduction processes in the southern part of the Neo-Tethyan domain (see Fig. 8b). Neo-Tethyan slab retreat, a process generally promoted in subduction zones by increased convergence velocities (Conrad, Bilek \& LithgowBertelloni, 2004; Schellart et al. 2007; Funiciello et al. 2008), is thought to have triggered the formation of these back-arc domains.

(2) Paleocene-Eocene (60-40 Ma; Fig. 10c-d/c'$\mathrm{d}^{\prime}$ ): the beginning of this period is marked by a slowing down of convergence (Fig. 8a) following slab retreat, and by a generalized slab break-off along the Zagros orogen. This combination results in an outwards magmatic shift from the SSZ to the Kermanshah region (and possibly near Neyriz; Babaie et al. 2001). By contrast, the end of this period witnesses an inwards magmatic shift (from the Kermanshah and the outer rim of the SSZ) to the UDMA and a surge in magmatic activity, probably related to the resumption of oceanic subduction below Eurasia. We propose that the distributed Middle Eocene magmatism and extension (core-complexes in Central Iran, extensional basins in the Alborz) results from enhanced coupling between the two plates and ablative subduction (flow-driven suction of the sub-continental lithosphere leading to partial delamination and melting; Fig. 10d, d'; Pope 


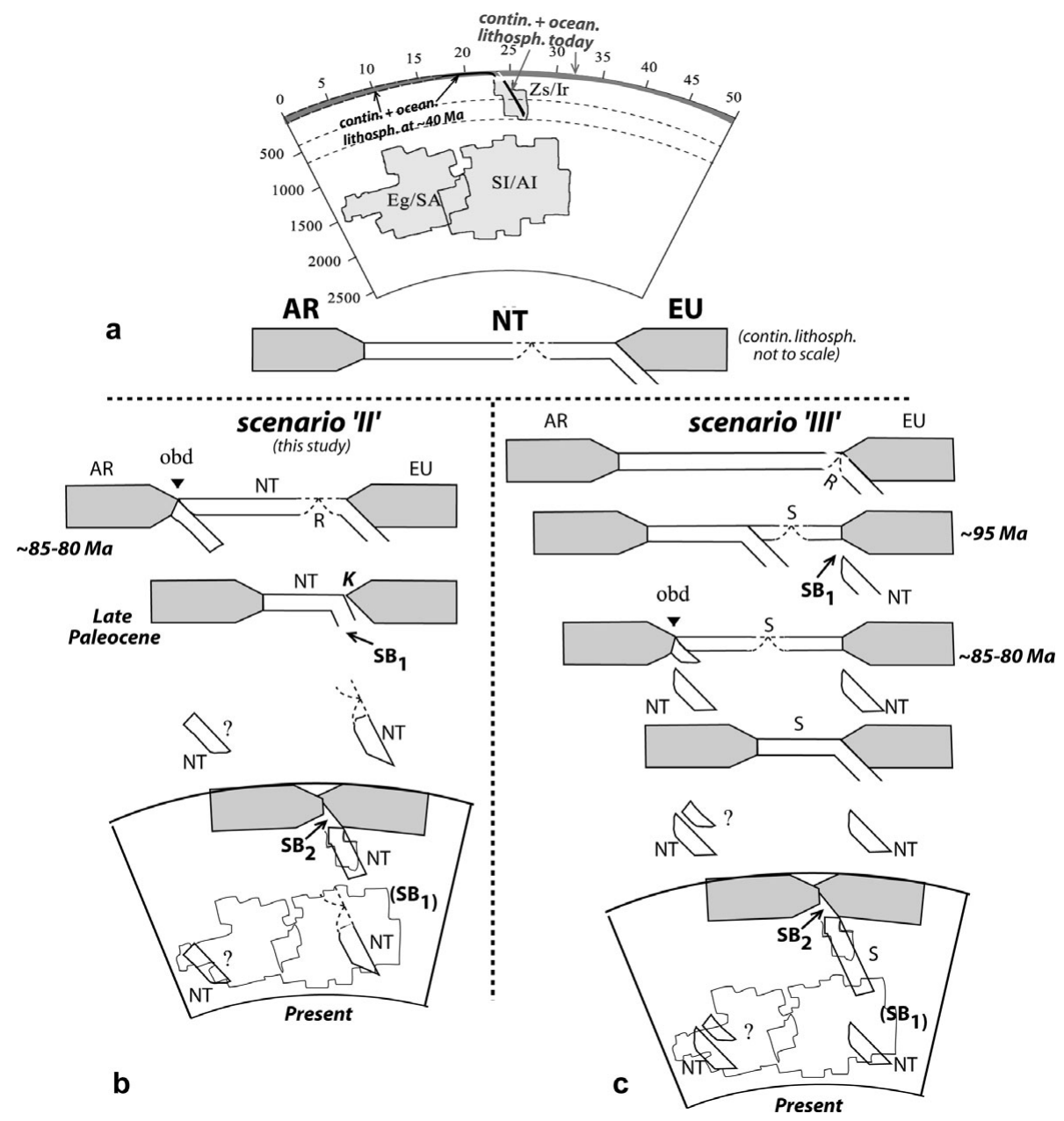

Figure 12. (a) Volume estimates of slab material at depth, after Hafkenscheid, Wortel \& Spakman (2006), and possible location of the oceanic and continental lithospheres at present and during Eocene time (40 Ma). (b) Scenario 'II' using Dercourt, Ricou \& Vrielynck's (1993) hypothesis, adapted from Hafkenscheid, Wortel \& Spakman (2006). This scenario is implicitly considered in our reconstructions (Figs 10, 11). (c) Scenario 'III' using Stampfli \& Borel's (2002) hypothesis, adapted from Hafkenscheid, Wortel \& Spakman (2006). Abbreviations: AR - Arabia; EU - Eurasia; K - Kermanshah; NT - Neo-Tethys; obd - obduction; R - ocean ridge; S - Semail; SB1 or 2 - slab break-off 1 or 2; AI, Eg, Ir, SA, SI, Zs - abbreviations for volume estimates of slab material at depth after Hafkenscheid et al. 2006.

\& Willett, 1998). Extension in the overriding plate could also, alternatively, result from the resumption of slab roll-back accompanying the renewed, effective subduction after slab break-off. Note that the above precollisional stages have either occurred without much construction of regional topography or the associated relief has been almost entirely erased to allow for the deposition of the Lower Miocene Qom Formation. In any case, the current topography largely results from the subsequent collisional stage.

(3) From Oligocene time onwards (35-30 Ma to present; Fig. $\left.10 \mathrm{e}-\mathrm{h} / \mathrm{e}^{\prime}-\mathrm{h}^{\prime}\right)$ : collision starts and leads to a progressive SW migration of shortening and orogenic build-up: a significant uplift successively affected the SSZ (20-15 Ma), the High Zagros (10 Ma) and the SFB (5-0 Ma). A second slab break-off leading to the formation of adakites during Late Miocene time (Omrani et al. 2008; Fig. 5e) took place below Central Iran (see also Molinaro, Zeyen \& Laurencin, 2005; Paul et al.2010), and probably migrated towards the NW in the light of tomographic constraints (Fig. 6) and adakite ages (younging northwards from c. 9 to $1 \mathrm{Ma}$; Chiu et al. 2010). This slab break-off at $\sim 10$ Ma below part of Central Iran and eastern Turkey (Keskin, Pearce \& Mitchell, 1998) probably contributed to the flare up in magmatism across much of the orogen (Fig. 2f). It may also have contributed to the reorganization of collision from the Pliocene onwards (e.g. Allen, Jackson \& Walker, 2004) through an increased coupling between the two plates ('head on' collision once slab pull is removed); an amplification of collisional movements is indeed noted in the Fars arc from 8-7 Ma onwards (Homke et al. 2004, 2010).

Our interpretation in terms of slab break-off and change of slab dip recalls the earlier suggestion from Berberian \& Berberian (1981, fig. 12), but differs from their interpretation in that: (i) magmatism at first did not migrate inwards but outwards (Kermanshah) before being located beneath the UDMA, (ii) magmatism in the Tarom-Alborz region is in fact coeval with magmatism in the UDMA (thus not requiring a slab steepening and swinging back as in Berberian \& Berberian, 1981), and (iii) closure had already happened in Mid-Miocene time. 
From estimates of slab material at depth, Hafkenscheid, Wortel \& Spakman (2006) concluded that they could not distinguish between a reconstruction broadly similar to ours (which they referred to as 'scenario II'; Dercourt, Ricou \& Vrielynck, 1993) and the one from Stampfli \& Borel (2002; 'scenario III'). These scenarios are further tested here (Fig. 12). In scenario II, obduction develops as a result of intraoceanic subduction to the south of the Neo-Tethys (Fig. 12b), whereas in scenario III ridge subduction below Eurasia triggers an early slab break-off and the formation of an extensive marginal basin, which is ultimately obducted (Fig. 12c; Stampfli \& Borel, 2002). Figure $12 b-c$ underlines that domains with high velocity material at depth can be accounted for by the two models and that both imply two stages of slab break-off (SB1, SB2; Fig. 12b, c), yet at different times. Our scenario (II) is preferred, however, for the following reasons: ridge subduction-related SB1 in scenario III would have to happen very early, at $c$. 95$90 \mathrm{Ma}$; scenario III does not account for the migration of magmatism from the SSZ to the UDMA, requires new subduction initiation at the foot of Eurasia and predicts a more voluminous slab material below Eurasia than scenario II; finally, scenario II alone explains the ETMD magmatic activity in the Kermanshah region (K, Fig. 12b). The back-arc basin noted 'S' (Fig. 12c) may, alternatively, be taken as representing the ETMD itself and having been accreted to Eurasia, but this would make it too old (unless only the latest magmatic products are accreted) or too distant from the continental margin (J. Braud, unpub. Ph.D. thesis, Univ. Paris-Sud, 1987).

\section{6.b. Further clues for regional geodynamics?}

A number of points should be clarified by future research:

(a) The widespread Eocene magmatism throughout Iran (Fig. 2d). In principle this could result from mantle delamination below Iran (although this is not supported, at least at the scale of the whole of Iran, by the seismic profiles of Paul et al. 2010) or from abundant subduction-related magma ascent through (extensional) deforming areas of the upper plate. We envision an intermediate hypothesis, whereby extension within the upper plate (as indicated in the crust by core-complex formation in Central Iran and extension in the Alborz) relates to vigorous, ablative subduction (as a result of the entrance of a more shallow-dipping slab after SB1) with traction-driven flow (and/or rapid thermal convection in a low viscosity asthenospheric mantle; Currie et al. 2004; Dilek, Altunkaynak \& Oner, 2010) leading to only partial removal of the lithospheric mantle below Iran.

The alkaline Oligocene magmatism in Sistan could also tentatively be related to localized mantle upwellings triggered by slabs resting on the $660 \mathrm{~km}$ discontinuity, as proposed by Faccenna et al. (2010). Given subduction rates, the Neo-Tethyan slab still sub- ducting after SB1 would indeed touch the discontinuity approximately $20 \mathrm{Ma}$ afterwards, hence approximately at 35-30 Ma (i.e. in Early Oligocene time or when Zagros collision started). Note, however, that the Sistan part of this widespread Eocene magmatism (Fig. 2d) could be completely unrelated to the Neo-Tethys and could result, instead, from slab break-off after closure of the small Sistan ocean. More geochemical data on the Late Eocene-Early Oligocene magmatism are thus clearly needed.

(b) Possible causes of the reorganization of collision since $10 \pm 5 \mathrm{Ma}$ (Allen, Jackson \& Walker, 2004; Homke et al. 2004; Molinaro et al. 2005; Ballato et al. 2010). This reorganization and broadening of the Zagros orogen could result from an increased coupling between the two plates as a result of slab break-off (Omrani et al.2008), from a change in the nature of the collision owing to the implication of an unstretched Arabian crust with normal thickness (Ballato et al. 2010), from a regional-scale kinematic reorganization from $5 \mathrm{Ma}$ onwards (Axen et al. 2001; Smit et al. $2010 a$ ) and/or from a positive climatic feedback (Allen $\&$ Armstrong, 2008).

(c) Why is there so little left (if anything) of the obducted ophiolite along the Zagros range (Fig. 4b)? The Oman ophiolite is well preserved because it has escaped collision so far, but large obducted ophiolite sheets were preserved in Turkey after collision (Okay, Harris \& Kelley, 1988). We speculate that this may relate to the initial 3D configuration (even in Oman, differences exist between the NW and the SE of the ophiolite); either less underthrusting of the continent (and therefore less obduction) or the underthrusting of a highly stretched continental margin below the ophiolite would indeed not favour a large isostatic rebound and future ophiolite preservation.

(d) What is the exact timing of inception of subduction? There are at present indications that subduction was active by $180-170 \mathrm{Ma}$, but more data is needed to tell whether subduction initiation took place during Late Triassic or Early/Middle Jurassic time.

(e) Has the Zagros orogen undergone long-lived deformation partitioning? Evidence for protracted (mainly dextral) shear indeed exists: Late Cretaceous in the SSZ (Mohajjel \& Fergusson, 2000; Mohajjel, Fergusson \& Sahandi, 2003; Sarkarinejad, 2007), Oligocene in the Crush Zone (Agard et al. 2005), OligoMiocene in the High Zagros (Axen et al. 2010) and at present across the whole of Iran (ZFTB and the Kazerun fault system, Kopet Dagh, etc; Talebian \& Jackson, 2002; Authemayou et al. 2006).

\section{6.c. A case study for upper plate deformation in a subduction context}

Our reconstructions of Arabia-Eurasia convergence across the Zagros point to the importance of mechanical coupling between the two plates in two critical time periods: Late Cretaceous and Late Paleocene. Upper plate deformation represents a useful proxy 
Table 1. Comparison of the Zagros orogen with the well-studied, adjacent Neo-Tethyan orogens from Turkey, the Himalayas and the Western Alps

\begin{tabular}{|c|c|c|c|c|c|c|c|c|c|c|c|}
\hline & \multicolumn{4}{|c|}{ Pre-collision } & \multirow{2}{*}{$\begin{array}{l}\text { Collision } \\
\\
\text { Timing } \\
(\mathrm{Ma})\end{array}$} & \multicolumn{6}{|c|}{ Post-collision } \\
\hline & $\begin{array}{l}\text { Obduct.? } \\
\text { Preserv.? }\end{array}$ & $\begin{array}{l}\text { Ocean. HP } \\
\text { remnants? }\end{array}$ & $\begin{array}{l}\text { Cont. subd. } \\
(\sim 10 \mathrm{Ma})\end{array}$ & UHP? & & $\begin{array}{l}\text { MP/MT } \\
\text { (crustal } \\
\text { stack.) }\end{array}$ & $\begin{array}{l}\text { Melting at } \\
\text { depths }\end{array}$ & $\begin{array}{l}\text { Slab } \\
\text { break-off } \\
\text { (Ma after } \\
\text { collision) }\end{array}$ & $\begin{array}{l}\text { Plateau \& } \\
\text { heat flow }\end{array}$ & $\begin{array}{l}\text { SKS /strike } \\
\text { orogen }\end{array}$ & $\begin{array}{l}\text { Channel } \\
\text { flow? }\end{array}$ \\
\hline W/C Alps & $\begin{array}{l}-? \\
-\end{array}$ & +++ & +++ & +++ & $35-30$ & $(+)$ & $(+)$ & 0 & - & - & - \\
\hline Turkey & $\begin{array}{l}+++ \\
+++\end{array}$ & +++ & +++ & $-?$ & 40 & + & +++ & $25-30$ & $\begin{array}{c}2000 \mathrm{~m} \\
\text { high }\end{array}$ & scattered & - \\
\hline Zagros & $\begin{array}{l}+ \\
-\end{array}$ & + & $+?$ & - & 30 & $-?$ & $-?$ & 20 & $\begin{array}{l}1500 \mathrm{~m} \\
\text { moderate }\end{array}$ & parallel & - \\
\hline Himalayas & $\begin{array}{l}++ \\
++\end{array}$ & + & +++ & +++ & 55 & +++ & +++ & 30 & $\begin{array}{c}5000 \mathrm{~m} \\
\text { high }\end{array}$ & parallel! & $+++?$ \\
\hline
\end{tabular}

Slab break-off after von Blanckenburg \& Davies (1995), Mahéo et al. (2002) and Keskin (2003) and references therein, for the Alps, Himalayas and Turkey, respectively. SKS below Zagros taken from Kaviani et al. (2009). See Section 6.d for discussion. Symbols: +++ , ,,+++- stand for large, moderate, some or none, respectively.

for plate-slab coupling and subduction zone behaviour (Funiciello et al. 2003; Conrad, Bilek \& Lithgow-Bertelloni, 2004; Lallemand, Heuret \& Boutelier, 2005; Regard et al. 2004): Lallemand et al. (2008) recently concluded that back-arc opening (or compression) develops if the upper plate velocity is larger (or smaller) than a certain threshold fraction of the lower plate velocity. Friction along the interplate contact and the mantle Stokes reaction acting on the slab are indeed the two main forces competing against slab pull (Arcay, Lallemand \& Doin, 2008). However, whether such changes may be regularly taking place through time, and on which time scale, is completely unknown.

The Arabia-Eurasia convergence across the Zagros provides an interesting case study and points to timescale changes in upper plate deformation of the order of 5-10 Ma: (1) Mid-Cretaceous extension marked by back-arc opening, mechanical decoupling along the subduction zone with blueschist exhumation and initiation of slab roll-back; (2) Late Cretaceous to Paleocene contraction, as testified by the closure of the back-arc domains; (3) Paleocene/Early Eocene extension, at least in the Kermanshah area (J. Braud, unpub. Ph.D. thesis, Univ. Paris-Sud, 1987), probably coincident with slow convergence and stagnant steep slab detachment (SB1); (4) Early Eocene compression (?) accompanying the increase in convergence velocities; (5) Middle Eocene extension throughout the whole upper plate (as testified by core-complexes and extensional volcanic basins); extension may be driven by renewed, efficient subduction traction (or, alternatively, by slab break-off below the tiny backarc domains, or both), and could be analogous to the late Mesozoic geodynamics of the eastern border of China (Charles et al. 2009); (6) Late Eocene/Early Oligocene contraction (Kargaranbafghi, Neubauer \& Genser, 2010), which is broadly coincident with the onset of collision; (7) intensification of shortening from Late Miocene time onwards (10-5 Ma to present).

Notwithstanding the need for more geological data (i.e. exact upper plate tectonic configuration during late Mesozoic time; see Saccani et al. 2010), it is also worth pointing out the contrasts between regions to the north and south of the Zagros orogen, on either side of a line running along the Kazerun and Doruneh faults, approximately (Fig. 13; see also Fig. 10a-g and a'$\left.\mathrm{g}^{\prime}\right)$. These 3D contrasts and along-strike variations can probably be accounted for by the complex interaction between inherited structures (from Palaeo-Tethyan closure times in Late Triassic time and even earlier), back-arc fragmentation and collision along the Zagros.

\section{6.d. Constraints for (Neo-Tethyan) orogens}

We finally discuss a possible comparison of the Zagros orogen with the well-studied, adjacent Neo-Tethyan orogens from Turkey, the Himalayas and the Western Alps. A detailed comparison between the Zagros and the Himalayas in terms of plateau and orogenic buildup was recently provided by Hatzfeld \& Molnar (2010). These authors concluded to similar processes operating during orogeny despite a less mature collision for the Zagros than for the Himalayas, primarily owing to differences in convergence velocities.

This type of comparison may prove difficult to generalize owing to important, first-order specific boundary conditions for each orogen: for example, the widespread extension in the Western Mediterranean domain after 35-30 Ma strongly influenced the later development of the collision in the Western (and to some extent Central) Alps, as did the escape of Anatolia for Turkey since Pliocene time or the much greater convergence velocities for the Himalayas (pre-collision convergence velocities with respect to Eurasia of 11 and $3 \mathrm{~cm} \mathrm{yr}{ }^{-1}$ for India and Arabia, respectively). Table 1 nevertheless attempts to provide some general statements, in part focusing on complementary aspects to those noted by Hatzfeld \& Molnar (2010). Table 1 shows that, by comparison with the Alps, the other three (Turkey, the Zagros and the Himalayas) have evolved into mature mountain belts, with collisionrelated plateaus (whose elevation broadly correlates with the duration of collision) underlain by significant heat flow, and share a typical time scale for slab breakoff of 20-30 Ma. 

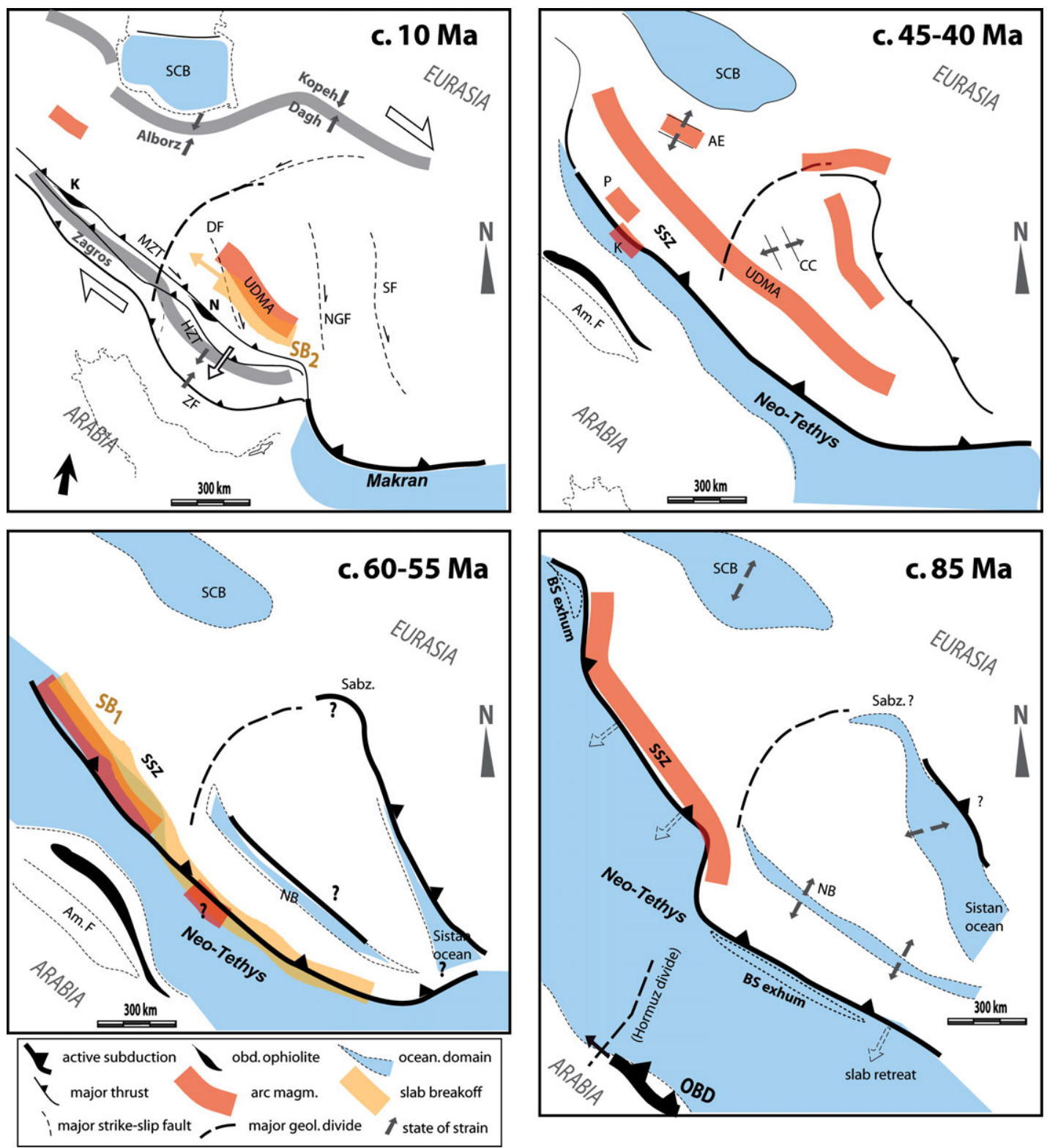

Figure 13. (Colour online) Snapshot maps showing some of the salient tectonic and magmatic events affecting the Eurasian upper plate and Central Iran, with emphasis on the geological contrasts found on either side of the Doruneh fault (compilation from available data cited in text). Reconstructions for Iran and the Neo-Tethys adapted from Barrier \& Vrielynck (2008). Abbreviations: AE - Alborz extension; Am F - Amiran flysch; BS - blueschist; CC - core-complex; DF - Dezful fault; HZT - High Zagros thrust; K - Kermanshah; N - Neyriz; NB - Nain-Baft; NGF - Nayband and Gowk faults; OBD - obduction; P - Piranshar; SB - slab break-off; Sabz. - Sabzevar; SCB - South-Caspian Basin; SF - Sistan Fault; ZF - Zagros thrust front; MZT, SSZ, UDMA - as for Fig. 1c, e.

In Tibet, models of plateau formation include crustal thickening and successive intracontinental subductions triggered by lithospheric strike-slip fault propagation (e.g. Meyer et al. 1998; Tapponnier et al. 2001) or bulk lithospheric shortening and subsequent removal of thickened lithospheric mantle (e.g. England \& Houseman, 1989; Molnar, England \& Martinod, 1993). In the Iranian plateau, there is neither evidence for a generalized sub-continental mantle delamination nor for any intracontinental subduction. The lack of present-day normal faulting in the Iranian plateau precludes extensional collapse (as noted by Hatzfeld \& Molnar, 2010). From our present-day knowledge of magmatism, the Iranian plateau may thus resemble E Turkey, where magmatism and deformation take place through a mixture of slab break-off, mantle delamination and strike-slip faulting (Keskin, 2003; Al-Lazki et al. 2004; Keskin, Genç \& Tüysüz, 2008; Sengör et al. 2008). Such complex magmatic patterns are now recognized below W Turkey too (Dilek \& Sandvol, 2009; Dilek, Altunkaynak \& Oner, 2010). Future research should therefore aim at better documenting gradients in magmatic type such as were reported for Turkey (i.e. increase of the slab component from north to south; Keskin, Pearce \& Mitchell, 1998; Keskin, 2003). By contrast to Turkey, however, there does not seem to be (yet) a major slab tear such as that advocated by Facenna et al. (2006) to allow for the tectonic escape of Anatolia (Flerit et al. 2004). 
An interesting specificity of the Zagros orogen (Table 1) may be that, although the strong influence of early, subduction stages is still largely visible (as discussed above), there are (1) only limited remnants of obduction or HP oceanic units, (2) no metamorphic relicts of continental subduction returned (although much of the distal margin of Arabia was subducted and is missing; Molinaro et al. 2005; Mouthereau et al. 2007), (3) no collision-related MP-MT metamorphism and therefore only moderate crustal stacking despite $\sim 30 \mathrm{Ma}$ of collision.

The absence of exhumation of the HP/UHP subducted continental margin (contrary to all other NeoTethyan belts; Table 1) may be due to the obducted ophiolite load onto Arabia (but Turkey and the Himalayas had a similar one), to the entrance of a highly thinned (and therefore not very buoyant) continental margin or, more likely, to insufficient slab pull provided by the remnant lithosphere sinking between the two slab break-offs (Figs 10d, d', 12b). Alternatively, we note that there was no such microcontinental block (easier to subduct) as the Bitlis-Püturge in Turkey, nor were the velocities as great as in the Himalayas (but HP/UHP developed in the Alps with very slow convergence velocities!).

Relatively minor crustal stacking at depth at present below the Zagros (as revealed by only localized crustal thickening, below the SSZ, and the lack of MPMT metamorphism) may hypothetically be related to insufficient slab pull too (as discussed above). This may relate to a much less mature orogeny than Turkey or the Himalayas, and one may wonder, in particular, why it takes 15-20 Ma for deformation to build-up in ZFTB. Ballato et al. (2010) recently suggested that this may represent the lag time between the initiation of continental collision (35-30 Ma; 'soft' collision with the stretched Arabian lithosphere) and the acceleration of regional deformation ( 15-10 Ma; 'hard' collision, when the unstretched Arabian lithosphere comes in). One may also think of a contribution from the Late Miocene slab break-off (SB2), which significantly reduces slab pull and will favour more frontal collision (Omrani et al. 2008; Van Hunen \& Allen, 2011). The comparison with the Alps, however, where the uplift of the external crystalline massifs (in a way similar to the High Zagros) also takes $\sim 20$ Ma but does not coincide with slab break-off (Von Blanckenburg \& Huw Davies, 1995; Table 1), suggests that this contribution may be small (or that Alpine slab break-off was comparatively limited).

\section{Conclusions}

We herein provide a review of our present knowledge of the Zagros orogeny and clues to Zagros geodynamics. We outline three main periods/regimes:

(1) Mid to Late Cretaceous time (115-85 Ma) corresponds to a distinctive period of perturbation of subduction processes and interplate mechanical coupling marked by blueschist exhumation and upper plate fragmentation;

(2) Paleocene-Eocene time (60-40 Ma) witnesses slab break-off, major shifts in arc magmatism and distributed extension within the upper plate;

(3) From Oligocene time onwards $(30 \pm 5 \mathrm{Ma}$ to present), collision develops with a progressive SW migration of deformation and topographic build-up (SSZ: 20-15 Ma, High Zagros: 12-8 Ma; SFB: 5$0 \mathrm{Ma}$ ), and is accompanied by a second, Late Miocene slab break-off ( $\sim 10$ Ma to present).

The Zagros shares similarities in orogenic buildup with neighbouring mountain belts developed at the expense of the Neo-Tethys (Alps, Turkey, Himalayas). Significant differences, on the other hand, include limited remnants of obduction or HP oceanic units, lack of continental subduction remnants and limited crustal stacking at depth despite $\sim 30 \mathrm{Ma}$ of collision. Another great difference with adjacent belts is that the Zagros orogen preserves an exceptional record of upper plate deformation, which should help better understand mechanical coupling between plates, with changes through time in the order of 5-10 Ma.

The Zagros orogeny thus appears intimately linked with the closure of the Neo-Tethys, from subduction/obduction processes to present-day collision (from $\sim 150$ to $0 \mathrm{Ma}$ ), and our reconstructions underline the key role played by oceanic subduction throughout the whole convergence history (see also Faccenna \& Becker, 2010). More generally, we finally stress that such a long-lasting subduction system with changing boundary conditions makes the Zagros orogen an ideal natural laboratory for subduction processes.

Acknowledgements. P. Agard acknowledges the support, over the years, from the Geological Survey of Iran (GSI) and the MEBE programme. This paper builds upon the Ph.D. of Jafar Omrani and later developments. The incentive for this paper also partly comes from solicitations from Y. Dilek (through the GSA Tectonic crossroads meeting; October 2010, Ankara) and O. Lacombe (this volume). Both are warmly thanked for triggering the write-up of this long-due manuscript. J. Omrani acknowledges the additional support from the French embassy in Tehran for a short stay in Paris, which was essential too. S. L. Chung and M. Zarrinkoub are thanked for lending us an early version of the results of Chiu et al. (2010). Reviews by M. Allen and M. Searle helped improve the manuscript. Warm thanks to J. Smit for discussion and corrections.

\section{References}

Agard, P., Augier, R. \& MoniÉ, P. 2010. Shear band formation and strain localization on a regional scale: Evidence from anisotropic rocks below a major detachment (Betic Cordilleras, Spain). Journal of Structural Geology 33, 114-31.

AgArd, P., Jolivet, L., VRielynck, B., Burov, E. \& Monie, P. 2007. Plate acceleration: The obduction trigger? Earth and Planetary Science Letters 258, 428-41.

Agard, P. \& Lemoine, M. 2005. Faces of the Alps. Paris: CGMW/CCGM, 48 pp. 
Agard, P., Monie, P., Gerber, W., Omrani, J., MoLiNARO, M., MEYer, B., LABrousSe, L., VRIELYNCK, B., JOLIVET, L. \& YAMATO, P. 2006. Transient, synobduction exhumation of Zagros blueschists inferred from $\mathrm{P}-\mathrm{T}$, deformation, time and kinematic constraints: Implications for Neotethyan wedge dynamics. Journal of Geophysical Research 111, B11401, doi:10.1029/2005JB004103, 28 pp.

Agard, P., OMrani, J., Jolivet, L. \& MOUTHEREAU, F. 2005. Convergence history across Zagros (Iran): constraints from collisional and earlier deformation. International Journal of Earth Sciences (Geologische Rundschau) 94, 401-19.

AghanABATI, A. \& RezAi, A. 2009. Correlation of lithostratigraphic units of Iran in major structural and sedimentary basins. National Geoscience Database of Iran.

Ahmadhadi, F., Lacombe, O. \& DANiEL, J. M. 2007. Early reactivation of basement faults in Central Zagros (SW Iran): evidence from pre-folding fracture populations in the Asmari Formation and Lower Tertiary paleogeography. In Thrust Belts and Foreland Basins; From fold kinematics to hydrocarbon systems (eds O. Lacombe, J. Lavé, J. Vergès, F. Roure), pp. 205-28. Springer Verlag.

Ahmadi KhalaJI, A., Esmaeily, D., Valizadeh, M. V. \& Rahimpour-Bonab, H. 2007. Petrology and geochemistry of the granitoid complex of Boroujerd, Sanandaj-Sirjan Zone, Western Iran. Journal of Asian Earth Sciences 29, 859-77.

Al-LazKi, A. I., SANDVOl, E., Seber, D., Barazangi, M., TURKELLI, N. \& MOHAMAD, R. 2004. Pn tomographic imaging of mantle lid velocity and anisotropy at the junction of the Arabian, Eurasian and African plates. Geophysical Journal International 158, 1024-40.

AlAVI, M. 1980. Tectonostratigraphic evolution of the Zagrosides of Iran. Geology 8, 144-9.

AlAVI, M. 1994. Tectonics of the Zagros orogenic belt of Iran: new data and interpretations. Tectonophysics 229, 211-38.

ALAVI, M. 2007. Structures of the Zagros Fold-Thrust Belt in Iran. American Journal of Science 307, 1064-95.

AlAVI, M. \& MAHDAVI, M. A. 1994. Stratigraphy and structures of the Nahavand region in western Iran and their implications for the Zagros tectonics. Geological Magazine 131, 43-7.

Alinaghi, A., Koulakov, I. \& Thybo, H. 2007. Seismic tomographic imaging of $\mathrm{P}$ - and S-waves velocity perturbations in the upper mantle beneath Iran. Geophysical Journal International 169, 1089-102.

Allen, M. B. \& ARMSTRONG, H. A. 2008. ArabiaEurasia collision and the forcing of mid-Cenozoic global cooling. Palaeogeography, Palaeoclimatology, Palaeoecology 265, 52-8.

Allen, M., Blanc, E. J.-P., Walker, R., Jackson, J., TAlEBIAN, M. \& GHASSEMI, M. R. 2006. Contrasting styles of convergence in the Arabia-Eurasia collision: Why escape tectonics does not occur in Iran. Geological Society of America Special Paper 409, 579-89.

Allen, M. B., GHassemi, M. R., Shahrabi, M. \& Qorashi, M. 2003. Accommodation of late Cenozoic oblique shortening in the Alborz range, northern Iran. Journal of Structural Geology 25, 659-72.

Allen, M., JACKSON, J. \& WALKER, R. 2004. Late Cenozoic reorganization of the Arabia-Eurasia collision and the comparison of short-term and longterm deformation rates. Tectonics 23, TC2008, doi:10.1029/2003TC001530, 16 pp.
Allen, M. B., Kheirkhah, M., Emami, M. H. \& Jones, S. J. 2011. Right-lateral shear across Iran and kinematic change in the Arabia-Eurasia collision zone. Geophysical Journal International 184, 555-74.

AMIDI, S. M., EMAMI, M. H. \& Michel, R. 1984. Alkaline character of Eocene volcanism in the middle part of Central Iran and its geodynamic situation. Geologische Rundschau 73, 917-32.

ArCaY, D., Lallemand, S. \& DoIn, M. P. 2008. Back-arc strain in subduction zones: Statistical observations versus numerical modeling. Geochemistry, Geophysics, Geosystems $\left(G^{3}\right)$ 9, Q05015, doi:10.1029/2007GC001875, 30 pp.

Arvin, M., Pan, Y., Dargahi, S., Malekizadeh, A. \& BABAEI, A. 2007. Petrochemistry of the Siah-Kuh granitoid stock southwest of Kerman, Iran: Implications for initiation of Neotethys subduction. Journal of Asian Earth Sciences 30, 474-89.

ARVIN, M. \& RoBInSON, P. T. 1994. The petrogenesis and tectonic setting of lavas from the Baft ophiolitic melange, southwest of Kerman, Iran. Canadian Journal of Earth Sciences 31, 824-34.

Authemayou, C., Bellier, O., Chardon, D., Benedetti, L., Malekzade, Z., Claude, C., Angeletti, B., SHABANIAN, E. \& ABBASSI, M. R. 2009. Quaternary slip-rates of the Kazerun and the Main Recent Faults: active strike-slip partitioning in the Zagros fold-andthrust belt. Geophysical Journal International 178, 52440.

Authemayou, C., Chardon, D., Bellier, O., MalekzADEH, Z., Shabanian, E. \& ABbassi, M. R. 2006. Late Cenozoic partitioning of oblique plate convergence in the Zagros fold-and-thrust belt (Iran). Tectonics 25, TC3002, doi:10.1029/2005TCOO1860, $21 \mathrm{pp.}$

AXen, G. J., Fakhari, M. D., Guest, B., GaVillot, Y., StOCKLI, D. F. \& HoRTON, B. K. 2010. Distributed oblique-dextral transpression in the High Zagros Mountains, Iran. In Tectonic Crossroads: Evolving Orogens of Eurasia-Africa-Arabia, Ankara, Turkey, Abstracts, p. 73.

Axen, G., Lam, P. S., Grove, M., Stockli, D. F. \& HASSANZADEH, J. 2001. Exhumation of the westcentral Alborz Mountains, Iran, Caspian subsidence, and collision-related tectonics. Geology 29, 559-62.

BABAeI, H., BABAeI, A., GHAZI, A. M. \& ArVIN, M. 2006. Geochemical, 40Ar/39Ar age, and isotopic data for crustal rocks of the Neyriz ophiolite, Iran. Canadian Journal of Earth Sciences 43, 57-70.

BABAIE, H. A., GHAZI, A. M., BABAEI, A., LA Tour, T. E. \& HASSANIPAK, A. A. 2001. Geochemistry of arc volcanic rocks of the Zagros Crush Zone, Neyriz, Iran. Journal of Asian Earth Sciences 19, 61-76.

Babazadeh, S. A. \& De Wever, P. 2006. Early Cretaceous radiolarian assemblages from radiolarites in the Sistan Suture (eastern Iran). Geodiversitas 26(2), 185206.

BAgHeRI, S. \& Stampfli, G. M. 2008. The Anarak, Jandaq and Posht-e-Badam metamorphic complexes in central Iran: New geological data, relationships and tectonic implications. Tectonophysics 451, 123-55.

Baharifar, A., MoINevaziri, H., Bellon, H. \& Piqué, A. 2004. The crystalline complexes of Hamadan (Sanandaj-Sirjan zone, western Iran): metasedimentary Mesozoic sequences affected by Late Cretaceous tectono-metamorphic and plutonic events. Comptes Rendus Geosciences 336, 1443-52.

BAHROUDI, A. \& KOYI, H. 2003. Effect of spatial distribution of Hormuz salt on deformation style in the Zagros 
fold and thrust belt: an analogue modelling approach. Journal of the Geological Society, London 160, 719-33.

Ballato, P., Mulch, A., Landgraf, A., Strecker, M. R., Dalconi, M. C., Friedrich, A. \& TABAtabaei, S. H. 2010. Middle to late Miocene Middle Eastern climate from stable oxygen and carbon isotope data, southern Alborz mountains, N Iran. Earth and Planetary Science Letters 300, 125-38.

Baroz, F., MaCaudière, J., Montigny, R., Noghreyan, M., OHnenstetter, M. \& RocCI, G. 1984. Ophiolites and related formations in the central part of the Sabzevar range (Iran) and possible geotectonic reconstructions. Neues Jahrbuch fur Geologie und Palaeontologie Abhteilungen 168, 358-88.

BARrIER, E. \& VRIELYNCK, B. 2008. Palaeotectonic maps of the Middle East. Tectono-sedimentary-palinspastic maps from Late Norian to Pliocene. 14 maps. Paris: CGMW/CCGM.

Benoit, M., Aguillon-Robles, A., Calmus, T., Maury, R. C., Bellon, H., Cotten, J., Bourgois, J. \& MichaUd, F. 2002. Geochemical diversity of Late Miocene volcanism in Southern Baja California, Mexico: Implication of mantle and crustal sources during the opening of an asthenospheric window. Journal of Geology 110, 627-48.

BERBERIAN, M. 1995. Master "blind" thrust faults hidden under the Zagros folds: active basement tectonics and surface morphotectonics. Tectonophysics 241, 193-5.

BERBERIAN, F. \& BERBERIAN, M. 1981. Tectono-plutonic episodes in Iran. In Zagros-Hindu Kush-Himalaya Geodynamic Evolution, vol. 3 (eds H. K. Gupta \& F. M. Delany), pp. 5-32. Washington, D.C.: American Geophysical Union.

BERBERIAN, M. \& KING, G. C. P. 1981. Towards a paleogeography and tectonic evolution of Iran. Canadian Journal of Earth Sciences 18, 1764-6.

Berberian, F., Muir, I. D., PANKHURSt, R. J. \& BERBERIAN, M. 1982. Late Cretaceous and early Miocene Andeantype plutonic activity in northern Makran and Central Iran. Journal of Geological Society, London 139, 60514

BlANC, E. J. P., Allen, M. B., IngER, S. \& HASSANI, H. 2003. Structural styles in the Zagros simple folded zone, Iran. Journal of the Geological Society, London 160, 401-12.

BRAUD, J. 1978. Geological map of Kermanshah, 1/250.000 scale. Tehran: Geological Survey of Iran.

BRAUD, J. \& RICOU, L. E. 1975. Eléments de continuité entre le Zagros et la Turquie du Sud-Est. Bulletin de la Societe Geologique de France 17, 1015-23.

BröCKer, M., Fotoohi Rad, G. R. \& Theunissen, S. 2010. New time constraints for HP metamorphism and exhumation of melange rocks from the Sistan suture zone, Eastern Iran. In Tectonic Crossroads: Evolving Orogens of Eurasia-Africa-Arabia, Ankara, Turkey, Abstracts, p. 37.

Brunet, M.-F., Korotaef, M. V., Ershov, A. V. \& Nikishin, A. M. 2003. The South Caspian Basin: a review of its evolution from subsidence modelling. Sedimentary Geology 156, 119-48.

CAMP, V. E. \& GRIFFIS, R. J. 1982. Character, genesis and tectonic setting of igneous rocks in the Sistan suture zone, eastern Iran. Lithos 15, 221-39.

Charles, N., Gumiaux, C., Augier, R., Chen, Y., Lin, W., FAURE, M. \& ZHU, R. 2009. Mesozoic continental extension in eastern China: Metamorphic Core Complexes and granitic plutons as time and strain markers. In American Geophysical Union, Fall Meeting 2009, GP21A-0759.
ChiU, H.-Y., Zarrinkoub, M. H., Chung, S.-L., Lin, I.-J., YANG, H.-M., LO, C.-H., MoHAMMADI, S. S. \& KHATIB, M. M. 2010. Zircon U-Pb age and geochemical constraints on the magmatic and tectonic evolution in Iran. In Tectonic Crossroads: Evolving Orogens of Eurasia-Africa-Arabia, Ankara, Turkey, Abstracts, p. 31.

COGNÉ, J. P. \& HuMLer, E. 2004. Temporal variations of oceanic spreading and crustal production rates during the last $180 \mathrm{My}$. Earth and Planetary Science Letters 227, 427-39.

Coleman, R. G. 1971. Plate tectonic emplacement of upper mantle peridotites along continental edges. Journal of Geophysical Research 76, 1212-22.

COLEMAN, R. G. 1981. Tectonic setting for ophiolite obduction in Oman. Journal of Geophysical Research 86, 2497-508.

Conrad, C. P., Bilek, S. \& Lithgow-Bertelloni, C. 2004. Great earthquakes and slab-pull: interaction between seismic coupling and plate-slab coupling. Earth and Planetary Science Letters 218, 109-22.

Currie, C. A., Wang, K., Hyndman, R. D. \& He, J. 2004. The thermal effects of steady-state slab-driven mantle flow above a subducting plate: the Cascadia subduction zone and backarc. Earth and Planetary Science Letters 223, 35-48.

Davoudian, A. R., Genser, J., Dachs, E. \& Shabanian, N. 2007. Petrology of eclogites from north of Shahrekord, Sanandaj-Sirjan Zone, Iran. Mineralogy and Petrology 92, 393-413.

Davoudian, A. R., Khalili, M., NoOrbehsht, I., Dachs, E., Genser, J. \& Shabanian, N. 2006. Geochemistry of metabasites in the north of the Shahrekord, SanandajSirjan Zone, Iran. Neues Jahrbuch für MineralogieAbhandlungen 182/3, 8-192.

DAVOUDZADEH, M. 1972. Geology and petrography of the area north of Nain, Central Iran. Tehran: Geological Survey of Iran Report no. 39, 89 pp.

DEFANT, M. J. \& DRUMMOND, M. S. 1990. Derivation of some modern arc magmas by melting of young subducted lithosphere. Nature 347, 662-5.

Dehghani, G. A. \& MAKRIS, J. 1984. The gravity field and crustal structure of Iran. Neues Jahrbuch für Mineralogie-Abhandlungen 168, 215-29.

Delaloye, M. \& DeSMONS, J. 1980. Ophiolites and melange terranes in Iran: A geochronological study and its paleotectonic implications. Tectonophysics 68, 83-111.

Dercourt, J., GAETANi, M., VRIELYNCK, B., BARrier, E., BiJu-Duval, B., Brunet, M. F., CADET, J. P., Crasquin, S. \& SANDulescu, M. 2000. Atlas Peri-Tethys, Palaeogeographical maps: 24 maps and explanatory notes. Paris: CCGM/CGMW

Dercourt, J., Ricou, L. E. \& VRIElynCK, B. 1993. Atlas Tethys Palaeoenvironmental maps, 14 maps, 1 pl. Paris: Gauthier-Villars.

Dercourt, J., Zonenshain, L. P., Ricou, L.-E., KAZMin, V. G., Le Pichon, X., KNipPeR, A. L., GrandjacQuet, C., Sbortshikov, I. M., Geyssant, J., LePvrier, C., Pechersky, D. H., Boulin, J., Sibuet, J.-C., SAVostin, L. A., Sorokhtin, O., Westphal, M., Bazhenov, M. L., LAUER, J. P. \& BIJU-DUVAL, B. 1986. Geological evolution of the Tethys belt from the Atlantic to the Pamirs since the LIAS. Tectonophysics 123, 241315.

Dewey, J. F., Helman, M. L., Turco, E., Hutton, D. H. W. \& KNOTT, S. D. 1989. Kinematics of the western Mediterranean. In Alpine Chain (eds M. P. Coward, D. Dietrich \& R. G. Park), pp. 265-83. Geological Society of London, Special Publication no. 45. 
Dilek, Y., Altunkaynak, A. \& Oner, Z., 2010. Synextensional granitoids in the Menderes core complex and the late Cenozoic extensional tectonics of the Aegean province. In Extending a Continent: Architecture, Rheology and Heat Budget (eds U. Ring \& B. P. Wernicke), pp. 197-223. Geological Society of London, Special Publication no. 321.

DileK, Y. \& SANDVOL, E. 2009. Seismic structure, crustal architecture and tectonic evolution of the AnatolianAfrican plate boundary and the Cenozoic orogenic belts in the Eastern Mediterranean Region. In Ancient Orogens and Modern Analogues (eds J. B. Murphy, J. D. Keppie \& A. J. Hynes), pp. 127-60. Geological Society of London, Special Publication no 327.

DimitriJeVIC, M. D. 1973. Geology of Kerman region. Tehran: Geological Survey of Iran.

ELloUZ-ZIMMERMANN, N., LALLEMANT, S. J., CASTILla, R., Mouchot, N., Leturmy, P., Battani, A., Buret, C., Cherel, L., DesaubliauX, G., Deville, E., Ferrand, J., LÜgke, A., MahieuX, G., Mascle, G., Mühr, P., Pierson-WickManN, A.-C., Robion, P., Schmitz, J., DANISH, M., HASANY, S., SHAHZAD, A. \& TABREEZ, A. 2007. Offshore frontal part of the Makran accretionary prim (Pakistan). The Chamak survey. In Thrust Belts and Foreland Basins; From fold kinematics to hydrocarbon systems (eds O. Lacombe, J. Lavé, J. Vergès \& F. Roure), pp. 351-66. Springer Verlag.

EMAMI, M. H. 2000. Magmatism in Iran. Tehran: Geological Survey of Iran.

England, P. \& Houseman, G. 1989. Extension during continental convergence, with application to the Tibetan Plateau. Journal of Geophysical Research 94, 1756179.

FACCENNA, C. \& BECKER, T. W. 2010. Shaping mobile belts by small-scale convection. Nature 465, 602-5.

FACCENNA, C., Becker, T. W., LALlemand, S., LAGaBRielle, Y., Funiciello, F. \& Piromallo, C. 2010. Subduction-triggered magmatic pulses: A new class of plumes? Earth and Planetary Science Letters 299, 54 68.

Faccenna, C., Bellier, O., Martinod, J., Piromallo, C. \& REGARD, V. 2006. Slab detachment beneath eastern Anatolia: A possible cause for the formation of the North Anatolian fault. Earth and Planetary Science Letters 242, 85-97.

FAKHARI, M. D., AXEN, G. J., HORTON, B. K., HASSANZADEH, J. \& AMINI, A. 2008. Revised age of proximal deposits in the Zagros foreland basin and implications for Cenozoic evolution of the High Zagros. Tectonophysics 451, 170 85.

FALCON, N. L. 1967. The geology of the north-east margin of the Arabian basement shield. Advancement of Science, London 24, 1-12.

FALCON, N. L. 1974. Southern Iran: Zagros Mountains. In Mesozoic-Cenozoic Orogenic Belts: Data for orogenic studies (ed. A. M. Spencer), pp. 199-211. Geological Society of London, Special Publication no. 4.

FARHOUDI, G. 1978. A comparison of Zagros geology to island arcs. Journal of Geology 86, 323-34.

Fazlnia, A., Moradian, A., Rezaei, K., MoAzzen, M. \& ALIPOUR, S. 2007. Synchronous activity of anorthositic and S-type granitic magmas in Chah-Dozdan batholith, Neyriz, Iran: evidence of zircon SHRIMP and monazite CHIME dating. Journal of Sciences, Islamic Republic of Iran 18, 221-37.

Flerit, F., Armijo, R., King, G. \& Meyer, B. 2004. The mechanical interaction between the propagating North Anatolian Fault and the back-arc extension in the Aegean. Earth and Planetary Science Letters 224, 347-62.

Fotoohi RaD, G. R., Droop, G. T. R., Amini, S. \& MOAZZEN, M. 2005. Eclogites and blueschists of the Sistan Suture Zone, eastern Iran: A comparison of P-T histories from a subduction melange. Lithos 84, 1-24.

Fotoohi Rad, G. R., Droop, G. T. R. \& Burgess, R. 2009. Early Cretaceous exhumation of high-pressure metamorphic rocks of the Sistan Suture Zone, eastern Iran. Geological Journal 44, 104-16.

Funiciello, F., FACCENNA, C., GIARDINI, D. \& REGENAUERLIEB, K. 2003. Dynamics of retreating slabs: 2. Insights from three-dimensional laboratory experiments. Journal of Geophysical Research 108(B4), 2207.

GANSSER, A. 1960. Ausseralpine Ophiolothprobleme. Eclogae Geologicae Helvetiae 52, 659-80.

Gavillot, Y., Axen, G. J., Stockli, D. F., Horton, B. K. \& FAKHARI, M. D. 2010. Timing of thrust activity in the High Zagros fold-thrust belt, Iran, from (U-Th)/He thermochronometry. Tectonics 29, TC4025, doi:10.1029/2009TC002484, 25 pp.

Ghalamghash, J., BoucheZ, J. L., VOSOUghi-ABEDINI, M. \& NÉdÉlEC, A. 2009. The Urumieh Plutonic Complex (NW Iran): Record of the geodynamic evolution of the Sanandaj-Sirjan zone during Cretaceous times - Part II: Magnetic fabrics and plate tectonic reconstruction. Journal of Asian Earth Sciences 36, 303-17.

GHARIB, F. \& DE WeVER, P. 2010. Radiolaires mésozoïques de la formation de Kermanshah (Iran). Comptes Rendus Palevol 9, 209-19.

GhazI, A. M. \& HaSsanipaK, A. A. 1999. Geochemistry of subalkaline and alkaline extrusives from the Kermanshah ophiolite, Zagros Suture Zone, Western Iran: implications for Tethyan plate tectonics. Journal of Asian Earth Sciences 17, 319-32.

Gidon, M., Berthier, F., Billiault, J. P., HalbronN, B. \& MAURIZOT, P. 1974. Sur les caractères et l'ampleur du coulissement de la "Main Fault" dans la région de Borudjerd-Dorud (Zagros oriental, Iran). Comptes Rendus de l'Académie des Sciences 278, 701-4.

Glennie, K. W., Boeuf, M. G. A., Clarke, M. W. H., Moody-Stuart, M., PilaAr, W. F. H. \& Reinhardt, B. M. 1973. Late Cretaceous nappes in Oman Mountains and their geologic evolution. American Association of Petroleum Geologists Bulletin 57, 5-27.

Goffé, B., Michard, A., Kienast, J. R. \& Le Mer, O. 1988. A case of obduction-related high-pressure, lowtemperature metamorphism in upper crustal nappes, Arabian continental margin, Oman. Tectonophysics 151, 363-86.

Guest, B., AXEN, G. J., LAM, P. S. \& HASSANZADEH, J. 2006. Late Cenozoic shortening in the west-central Alborz Mountains, northern Iran, by combined conjugate strikeslip and thin-skinned deformation. Geosphere 2, 35-52.

Guest, B., Guest, A. \& Axen, G. 2007. Late Tertiary tectonic evolution of northern Iran: A case for simple crustal folding. Global and Planetary Change 58, 43553.

HACKer, B., Mosenfelder, J. L. \& GNos, E. 1996. Rapid emplacement of the Oman ophiolite: thermal and geochronologic constraints. Tectonics 15, 1230-47.

HAFKENSCHEID, E., WORTEl, M. J. R. \& SpaKMAN, W. 2006. Subduction history of the Tethyan derived seismic tomography and tectonic reconstruction. Journal of Geophysical Research 111, B08401, doi:10.1029/2005JB003791, 26 pp.

Haghipour, A. 1974. Etude géologique de la région de Biabanak-Bafq (Iran Central); pétrologie et tectonique 
du socle Précambrien et de sa couverture. These, Université Scientifique et Médicale de Grenoble, 403 pp.

HaQ, B. U., Hardenbol, J. \& VaIL, P. R. 1987. Chronology of fluctuating sea levels since the Triassic. Science $\mathbf{2 3 5}$, 1156-67.

Hassanzadeh, J., Stockli, D. F., Horton, B. K., Axen, G. J., Stockli, L. D., Grove, M., Schmitt, A. K. \& WALKER, J. D. 2008. U-Pb zircon geochronology of late Neoproterozoic-Early Cambrian granitoids in Iran: implications for paleogeography, magmatism, and exhumation history of Iranian basement. Tectonophysics 451, 71-96.

HATZFELD, D. \& Molnar, P. 2010. Comparisons of the kinematics and deep structures of the Zagros and Himalaya and of the Iranian and Tibetan plateaus and geodynamic implications. Reviews of Geophysics 48, RG2005, doi:10.1029/2009RG000304, 48 pp.

HAYNES, S. J. \& MCQUILLAN, H. 1974. Evolution of the Zagros Suture Zone, Southern Iran. Geological Society of America Bulletin 85, 739-44.

Hessami, K., Koyi, H., Talbot, C. J., TABasi, H. \& Shabanian, E. 2001. Progressive unconformities within an evolving foreland fold-thrust belt, Zagros Mountains. Journal of the Geological Society, London 158, 969-81.

HOLLINGSWORTH, J., JACKSON, J., WALKER, R. \& NAZARI, H. 2008. Extrusion tectonics and subduction in the eastern South Caspian region since $10 \mathrm{Ma}$. Geology 36, 763-6.

HOMKE, S., VERGÈs, J., GARCÉS, M., EMAMI, H. \& KARPUZ, R. 2004. Magnetostratigraphy of Miocene-Pliocene Zagros foreland deposits in the front of the Push-e Kush Arc (Lurestan Province, Iran). Earth and Planetary Science Letters 225, 397-410.

Homke, S., Vergés, J., Serra-Kiel, J., Bernaola, G., ShARP, I., GARCÉS, M., MONTERO-VERdÙ, I., KARPUZ, R. \& GoodarzI, M. H. 2009. Late CretaceousPaleocene formation of the proto-Zagros foreland basin, Lurestan Province, SW Iran. Geological Society of America Bulletin 121, 963-78.

Homke, S., Verges, J., VAn Der Beek, P., Fernandez, M., SAURA, E., BARBERO, L., BADICS, B. \& LABRIN, E. 2010. Insights in the exhumation history of the NW Zagros from bedrock and detrital apatite fission-track analysis: evidence for a long-lived orogeny. Basin Research 22, 659-80.

JACKSON, J., HAINS, J. \& HOLT, W. 1995. The accommodation of Arabia-Eurasia plate convergence in Iran. Journal of Geophysical Research 100, 15205-19.

Jackson, J., Priestley, K., Allen, M. \& Berberian, M. 2002. Active tectonics of the South Caspian Basin. Geophysical Journal International 148, 214-45.

JAHANGIRI, A. 2007. Post-collisional Miocene adakitic volcanism in NW Iran: geochemical and geodynamic implications. Journal of Asian Earth Sciences 30, 43347.

JAHANI, S., CALlot, J.-P., LeTOUZEY, J. \& FrizON DE LAmotTE, D. 2009. The eastern termination of the Zagros Fold-and-Thrust Belt, Iran: Structures, evolution, and relationships between salt plugs, folding, and faulting. Tectonics 28, TC6004, doi:10.1029/2008TC002418, 22 pp.

JAMES, G. S. \& WYND, J. G. 1965. Stratigraphic nomenclature of Iranian Oil Consortium Agreement area. American Association of Petroleum Geologists Bulletin 49, 2182-245.

JOLIVET, L. \& FACCENNA, C. 2000. Mediterranean extension and the Africa-Eurasia collision. Tectonics 19, 1095106.
Kargaranbafghi, F., Neubauer, F. \& Genser, J. 2010. Cenozoic kinematic evolution of southwestern Central Iran: Strain partitioning and accommodation of Arabia-Eurasia convergence. Tectonophysics 502, 22143.

Kaviani, A., Hatzfeld, D., Paul, A., Tatar, M. \& PRIESTLEY, K. 2009. Shear-wave splitting, lithospheric anisotropy, and mantle deformation beneath the ArabiaEurasia collision zone in Iran. Earth and Planetary Science Letters 286, 371-8.

Kaviani, A., Paul, A., Bourova, E., HatzFeld, D., Pedersen, H. \& MoKhtari, M. 2007. A strong seismic velocity contrast in the shallow mantle across the Zagros collision zone (Iran). Geophysical Journal International 171, 399-410.

KESKIN, M. 2003. Magma generation by slab steepening and breakoff beneath a subduction-accretion complex: An alternative model for collision-related volcanism in Eastern Anatolia, Turkey. Geophysical Research Letters 30, 8046, doi:10.1029/2003GL018019, 4 pp.

Keskin, M., Genç, S. C. \& TÜYsüZ, O. 2008. Petrology and geochemistry of post-collisional Middle Eocene volcanic units in North-Central Turkey: Evidence for magma generation by slab breakoff following the closure of the Northern Neotethys Ocean. Lithos 104, 267305.

Keskin, M., Pearce, J. A. \& Mitchell, J. G. 1998. Volcano-stratigraphy and geochemistry of collisionrelated volcanism on the Erzurum-Kars Plateau, North Eastern Turkey. Journal of Volcanology and Geothermal Research 85, 355-404.

Khadivi, S., MouthereaU, F., LARrasoaña, J. C., Vergés, J., Lacombe, O., Khademi, E., Beamud, E., MelinteDOBRINESCU, M. \& SUC, J.-P. 2010. Magnetochronology of synorogenic Miocene foreland sediments in the Fars arc of the Zagros Folded Belt (SW Iran). Basin Research 22, 918-32.

Khan, S. D., Flower, M. F. J., Sultan, M. I. \& SANDVOL, E. 2006. Introduction to TETHYS - an interdisciplinary GIS database for studying continental collisions. Journal of Asian Earth Sciences 26, 613-25.

Kheirkhah, M., Allen, M. B. \& EMAMi, M. 2009. Quaternary syn-collision magmatism from the Iran/Turkey borderlands. Journal of Volcanology and Geothermal Research 182, 1-12.

KoOP, W. J., Stoneley, R., Ridd, M. F., Murphy, R. W., Osmaston, M. F. \& Kholief, M. M. 1982. Subsidence history of the Middle East Zagros basin, Permian to Recent [and discussion]. Philosophical Transactions of the Royal Society of London. Series A, Mathematical and Physical Sciences 305, 149-68.

Koyi, H. A., Ghasemi, A., Hessami, K. \& Dietl, C. 2008. The mechanical relationship between strike-slip faults and salt diapirs in the Zagros fold-thrust belt. Journal of the Geological Society, London 165, 1031-44.

Lacombe, O., Amrouch, K., Mouthereau, F. \& Dissez, L. 2007. Calcite twinning constraints on late Neogene stress patterns and deformation mechanisms in the active Zagros collision belt. Geology 35, 263-6.

Lacombe, O., Mouthereau, F., Kargar, S. \& Meyer, B. 2006. Late Cenozoic and modern stress fields in the western Fars (Iran): implications for the tectonic and kinematic evolution of central Zagros. Tectonics $\mathbf{2 5}$, TC1003, doi:10.1029/2005TC001831, 27 pp.

Lallemand, S., Heuret, A. \& Boutelier, D. 2005. On the relationships between slab dip, back-arc stress, upper plate absolute motion, and crustal nature in subduction zones. Geochemistry, Geophysics, Geosystems $\left(G^{3}\right) \mathbf{6}$, Q09006, doi:10.1029/2005GC000917, 18 pp. 
Lallemand, S., Heuret, A., Faccenna, C. \& FUNICIELLO, F. 2008. Subduction dynamics as revealed by trench migration. Tectonics 27, TC3014, doi:10.1029/2007TC002212, 15 pp.

LANPHERE, M. A. \& PAMIC, J. 1983. ${ }^{40} \mathrm{Ar} /{ }^{39} \mathrm{Ar}$ Ages and tectonic setting of ophiolite from the Neyriz area, southeast Zagros Range, Iran. Tectonophysics 96, 24556.

LARSON, R. L. 1991. Latest pulse of the Earth: evidence for a mid-Cretaceous superplume. Geology 19, 547-50.

LE DorTZ, K., MEYER, B., SÉBrIER, M., NAZARI, H., Braucher, R., FatTahi, M., BenedetTi, L., Foroutan, M., Siame, L., Bourlès, D., TAlebian, M., BAteman, M. D. \& Ghoraishi, M. 2009. Holocene right-slip rate determined by cosmogenic and OSL dating on the Anar fault, Central Iran. Geophysical Journal International 179, 700-10.

LETERRIER, J. 1985. Mineralogical, geochemical and isotopic evolution of two Miocene mafic intrusions from the Zagros (Iran). Lithos 18, 311-29.

Leturmy, P., Molinaro, M. \& Frizon De Lamotte, D. 2010. Structure, timing and morphological signature of hidden reverse basement faults in the Fars Arc of the Zagros (Iran). In Tectonic and Stratigraphic Evolution of Zagros and Makran during the Mesozoic-Cenozoic (eds P. Leturmy \& C. Robin), pp. 121-38. Geological Society of London, Special Publication no. 330.

MAHÉO, G., GuILlOT, S., BlicherT-TOFT, J., Rolland, Y. \& PÊCHER, A. 2002. A slab breakoff model for the Neogene thermal evolution of South Karakorum and South Tibet. Earth and Planetary Science Letters 195, 45-58.

MANGINO, K. \& PRIESTLEY, K. 1998. The crustal structure of the southern Caspian region. Geophysical Journal International 133, 630-48.

Martin, H., SMithies, R. H., Rapp, R., MOYen, J.-F. \& CHAMPION, D. 2005. An overview of adakite, tonalitetrondhjemite-granodiorite (TTG), and sanukitoid: relationships and some implications for crustal evolution. Lithos 79, 1-24.

Masoudi, F., YARdLeY, B. W. D. \& ClifF, R. A. 2002. Rb$\mathrm{Sr}$ geochronology of pegmatites, plutonic rocks and a hornfels in the region south-west of Arak, Iran. Journal of Sciences, Islamic Republic of Iran 13, 249-54.

MASSON, F. D. R., ANVARI, M., DJAMOUR, Y., WALPERSDORF, A., TaVaKoli, F., Daignières, M., NANKali, H. \& VAN GORP, S. B. 2007. Large-scale velocity field and strain tensor in Iran inferred from GPS measurements: new insight for the present-day deformation pattern within NE Iran. Geophysical Journal International 170, 43640.

MASSON, F., DJAMOUR, Y., VAN GORP, S., CHERY, J., TATAR, M., TaVakoli, F., Nankali, H. \& Vernant, P. 2006. Extension in NW Iran driven by the motion of the South Caspian Basin. Earth and Planetary Science Letters 252, $180-8$.

Mazhari, S. A., Amini, S., Ghalamghash, J. \& BeA, F. 2009a. Petrogenesis of granitic unit of Naqadeh complex, Sanandaj-Sirjan Zone, NW Iran. Arabian Journal of Geosciences, doi:10.1007/s12517-0090077-6.

Mazhari, S. A., Bea, F., Amini, S., Ghalamghash, J., MOLINA, F., MONTERo, P., SCARROW, J. H. \& Williams, I. S. 2009b. The Eocene bimodal Piranshahr massif of the Sanandaj-Sirjan Zone, NW Iran: a marker of the end of the collision in the Zagros orogen. Journal of Geological Society, London 166, 53-69.

MCCALL, G. J. H. 1997. The geotectonic history of the Makran and adjacent areas of southern Iran. Journal of Asian Earth Sciences 15, 517-31.
McCALL, G. J. H. \& KIDD, R. G. W. 1982. The Makran, Southeastern Iran: the anatomy of a convergent plate margin active from Cretaceous to Present. In TrenchForearc Geology: Sedimentation and Tectonics on Modern and Ancient Active Plate Margins (ed. J. K. Leggett), pp. 387-97. Geological Society of London, Special Publication no. 10.

McClusky, S., BAlassanian, S., Barka, A., Demir, C., ERgintaV, S., GeORgIEV, I., GURKAN, O., HAMBURGER, M., Hurst, K., Kahle, H., Kastens, K., KeKelidze, G., King, R., Kotzev, V., LenK, O., Mahmoud, S., Mishin, A., NADARIYA, M., OUZOUnIS, A., PARAdisSis, D., Peter, Y., Prilepin, M., Reilinger, R., SAnli, I., Seeger, H., Tealeb, A., Toksoz, M. N. \& Veis, G. 2000. Global Positioning System constraints on plate kinematics and dynamics in the eastern Mediterranean and Caucasus. Journal of Geophysical Research 105, 5695-719.

MCQUARRIE, N. 2004. Crustal scale geometry of the Zagros fold-thrust belt, Iran. Journal of Structural Geology 26, 519-35.

MCQuarrie, N., Stock, J. M., Verdel, C. \& Wernicke, B. P. 2003. Cenozoic evolution of Neotethys and implications for the causes of plate motions. Geophysical Research Letters 30, doi:10.1029/2003GL017992, 4 pp.

MeYer, B. \& Le DorTZ, K. 2007. Strike-slip kinematics in Central and Eastern Iran: Estimating fault slip-rates averaged over the Holocene. Tectonics 26, TC5009, doi:10.1029/2006TC002073, 20 pp.

Meyer, B., Mouthereau, F., Lacombe, O. \& Agard, P. 2006. Evidence of Quaternary activity along the Deshir Fault: implication for the Tertiary tectonics of Central Iran. Geophysical Journal International 164, 192-201.

Meyer, B., Tapponnier, P., Bourjot, L., Métivier, F., Gaudemer, Y., Peltzer, G., Shunmin, G. \& Zhitai, C. 1998. Crustal thickening in Gansu-Qinghai, lithospheric mantle subduction, and oblique, strike-slip controlled growth of the Tibet plateau. Geophysical Journal International 135, 1-47.

Mirnejad, H., HASSANZADEH, J., COUSENS, B. L. \& TAYLOR, B. E. 2010. Geochemical evidence for deep mantle melting and lithospheric delamination as the origin of the inland Damavand volcanic rocks of northern Iran. Journal of Volcanology and Geothermal Research 198 , 288-96.

MohajJel, M. \& Fergusson, C. L. 2000. Dextral transpression in Late Cretaceous continental collision, SanandajSirjan Zone, western Iran. Journal of Structural Geology 22, 1125-39.

Mohajuel, M., Fergusson, C. L. \& Sahandi, M. R. 2003. Cretaceous-Tertiary convergence and continental collision, Sanandaj-Sirjan Zone, western Iran. Journal of Asian Earth Sciences 21, 397-412.

Molinaro, M., Leturmy, P., Guezou, J. C., Frizon De LAMOTTE, D. \& Eshraghi, S. A. 2005. The structure and kinematics of the southeastern Zagros fold-thrust belt, Iran: from thin-skinned to thick-skinned tectonics. Tectonics 24, TC3007, doi:10.1029/2004TC001633, $19 \mathrm{pp}$.

Molinaro, M., ZeYen, H. \& LAURencin, X. 2005. Lithospheric structure beneath the south-eastern Zagros Mountains, Iran: recent slab break-off? Terra Nova 17, $1-6$.

Molnar, P., England, P. \& Martinod, J. 1993. Mantle dynamics, the uplift of the Tibetan Plateau, and the Indian monsoon. Reviews in Geophysics 31, 357-96.

MoniÉ, P. \& AGARD, P. 2009. Coeval blueschist exhumation along thousands of kilometers: Implications for subduction channel processes. Geochemistry, Geophysics, Geo- 
systems $\left(G^{3}\right)$ 10, Q07002, doi:10.1029/2009GC002428, $12 \mathrm{pp}$.

Morley, C. K., Kongwung, B., Julapour, A. A., AbDolghafourian, M., HaJian, M., Waples, D., WARREN, J., OtTERDOOM, H., SRISURIYON, K. \& KAZEMI, H. 2009. Structural development of a major late Cenozoic basin and transpressional belt in central Iran: The Central Basin in the Qom-Saveh area. Geosphere 5, 325-62.

MotiEI, H. 1993. Stratigraphy of Zagros. Tehran: Geological Survey of Iran.

Mouthereau, F., Lacombe, O. \& Meyer, B. 2006. The Zagros folded belt (Fars, Iran): constraints from topography and critical wedge modelling. Geophysical Journal International 165, 336-56.

Mouthereau, F., Tensi, J., Bellahsen, N., Lacombe, O., De Boisgrollier, T. \& KARGAR, S. 2007. Tertiary sequence of deformation in a thin-skinned/thick-skinned collision belt: The Zagros Folded Belt (Fars, Iran). Tectonics 26, TC5006, doi: 10.1029/2007TC002098, $28 \mathrm{pp}$.

NADIMI, A. 2007. Evolution of the Central Iranian basement. Gondwana Research 12, 324-33.

NAVABPouR, P., ANGELIER, J. \& BARRIER, E. 2007. Cenozoic post-collisional brittle tectonic history and stress reorientation in the High Zagros Belt (Iran, Fars Province). Tectonophysics 432, 101-31.

OBERHÄNSLI, R., BOUSQUET, R., MOINZADEH, H., MOAZZEN, M. \& ARVIN, M. 2007. The field of stability of blue Jadeite: A new occurrence of jadeitite at Sorkhan, Iran, as a case study. Canadian Mineralogist 45, 15019.

Okay, A., Harris, N. B. W. \& Kelley, S. P. 1988. Exhumation of blueschists along a Tethyan suture in northwest Turkey. Tectonophysics 285, 275-99.

Omrani, J., Agard, P., Whitechurch, H., Benoit, M., Prouteau, G. \& Jolivet, L. 2008. Arc-magmatism and subduction history beneath the Zagros Mountains, Iran: A new report of adakites and geodynamic consequences. Lithos 106, 380-98.

Omrani, J., Agard, P., Whitechurch, H., Benoit, M., Prouteau, G. \& Jolivet, L. 2009. Reply to: Comment by Aftabi and Atapour on "Arc magmatism and subduction history beneath the Zagros Mountains, Iran: A new report of adakites and geodynamic consequences". Lithos 113, 847-9.

Oveisi, B., Lavé, J., Van Der Beek, P., Carcaillet, J., Benedetti, L. \& Aubourg, C. 2009. Thick- and thinskinned deformation rates in the central Zagros simple folded zone (Iran) indicated by displacement of geomorphic surfaces. Geophysical Journal International 176, 627-54.

Paul, A., Hatzfeld, D., Kaviani, A., Tatar, M. \& Pequegnat, C. 2010. Seismic imaging of the lithospheric structure of the Zagros mountain belt (Iran). In Tectonic and Stratigraphic Evolution of Zagros and Makran during the Mesozoic-Cenozoic (eds P. Leturmy \& C. Robin), pp. 5-18. Geological Society of London, Special Publication no. 330 .

Paul, A., Kaviani, A., Hatzfeld, D., Vergne, J. R. M. \& MOKHTARI, M. 2006. Seismological evidence for crustal-scale thrusting in the Zagros mountain belt (Iran). Geophysical Journal International 166, 227-37.

Pearce, J. A., Bender, J. F., De Long, S. E., KidD, W. S. F., Low, P. J., Guner, Y., SAROGLU, F., YilmaZ, Y., Moorbath, S. \& Mitchell, J. G. 1990. Genesis of collision volcanism in Eastern Anatolia, Turkey. Journal of Volcanology and Geothermal Research 44, 189229.

Pillevuit, A., Marcoux, J., Stampfli, G. \& Baud, A. 1997. The Oman Exotics: a key to the understanding of the Neotethyan geodynamic evolution. Geodinamica Acta 10, 209-38.

Pope, D. C. \& WiLleTt, S. D. 1998. Thermal-mechanical model for crustal thickening in the central Andes driven by ablative subduction. Geology 6, 511-14.

PRIESTLEY, K. \& MCKENZIE, D. 2006. The thermal structure of the lithosphere from shear wave velocities. Earth and Planetary Science Letters 244, 285-301.

RACHIDNEJAD-OMRAN, N., EMAMI, M. H., SABZEHEI, M., Rastad, E., Bellon, H. \& PiQué, A. 2002. Lithostratigraphie et histoire paléozoïque à paléocène des complexes métamorphiques de la région de Muteh, zone de Sanandaj-Sirjan (Iran méridional). Comptes Rendus de l'Académie des Sciences 334, 1185-91.

RADJAeE, A., RHAM, D., MOKHTARI, M., TATAR, M., PRIESTLEY, K. \& HATZFELD, D. 2010. Variation of Moho depth in the central part of the Alborz Mountains, northern Iran. Geophysical Journal International 181, 173-84.

Regard, V., Bellier, O., Thomas, J.-C., AbBassi, M., Mercier, J., Shabanian, E., Feghit, K. \& SoLEYMANI, S. 2004. Accomodation of Arabia-Eurasia convergence in the Zagros-Makran transfer zone, SE Iran: A transition between collision and subduction through a young deformation system. Tectonics 23, TC4007, doi:10.1029/2003TC001599, 24 pp.

Regard, V., HatzFeld, D., Molinaro, M., Aubourg, C., BAYER, R., Bellier, O., YAMini-FARd, F., PEYRET, M. \& ABBASSI, M. 2010. The transition between Makran subduction and the Zagros collision: recent advances in its structure and active deformation. In Tectonic and Stratigraphic Evolution of Zagros and Makran during the Mesozoic-Cenozoic (eds P. Leturmy \& C. Robin), pp. 43-64. Geological Society of London, Special Publication no. 330.

REILINGER, R. \& MCCLUSKY, S. 2010. Subduction drives Arabia/Africa plate convergence with Eurasia and provides a unifying, dynamic mechanism for Mediterranean/Middle East tectonics. In Tectonic Crossroads: Evolving Orogens of Eurasia-Africa-Arabia, Ankara, Turkey, Abstracts, p. 41.

REYRE, D. \& MOHAFEZ, S. 1970. Une premiére contribution des accord NIOC-ERAP a la connaissance geologique de l'Iran. Revue de l'Institut Français du Pétrole 25, 945-54.

RiCOU, L. E. 1971. Le croissant ophiolitique péri-arabe, une ceinture de nappes mise en place au crétacé supérieur. Revue de Géographie Physique et de Géologie Dynamique 13, 327-50.

RICOU, L. E. 1994. Tethys reconstructed: plates, continental fragments and their boundaries since $260 \mathrm{Ma}$ from Central America to South-eastern Asia. Geodinamica Acta 7, 169-218.

RicoU, L.-E., BRAUD, J. \& BRUNN, J. H. 1977. Le Zagros. In Livre à la mémoire de A.F. de Lapparent (1905-1975). Mémoire hors Série de la Société Géologique de France 8, 33-52.

Ritz, J.-F., Nazari, H., Ghassemi, A., Salamati, R., SHAFEI, A., SOlAYMANI, S. \& VERNANT, P. 2006. Active transtension inside central Alborz: A new insight into northern Iran-southern Caspian geodynamics. Geology 34, 477-80.

Robertson, A. H. F. 1987. Upper Cretaceous Muti Formation: transition of a Mesozoic carbonate platform to a 
foreland basin in the Oman Mountains. Sedimentology 34, 1123-42.

Robin, C., Gorican, S., Guillocheau, F., Razin, P., Dromart, G. \& Mosaffa, H. 2010. Mesozoic deepwater carbonate deposits from the southern Tethyan passive margin in Iran (Pichakun nappes, Neyriz area): biostratigraphy, facies sedimentology and sequence stratigraphy. In Tectonic and Stratigraphic Evolution of Zagros and Makran during the Mesozoic-Cenozoic (eds P. Leturmy \& C. Robin), pp. 179-210. Geological Society of London, Special Publication no. 330.

Rosenbaum, G., Lister, G. S. \& DuBOZ, C. 2002. Relative motions of Africa, Iberia and Europe during Alpine orogeny. Tectonophysics 359, 117-29.

Rossetti, F., Nasrabady, M., Vignaroli, G., Theye, T., Gerdes, A., RazaVI, M. H. \& Vaziri, H. M. 2009. Early Cretaceous migmatitic mafic granulites from the Sabzevar range (NE Iran): implications for the closure of the Mesozoic peri-Tethyan oceans in central Iran. Terra Nova 22, 26-34.

SABZEHEI, M., BERBERIAN, M., ROSHANRAVAN, J., AZIZAN, H., NAZEMZADEH, M., AlaVI-TEHRANI, N., Houchmand-Zadeh, A., Nowgole-Sadat, M. A. A. \& MADJIDI, M. 1994. Geological map of Hajiabad, 1/250,000 scale. Tehran: Geological survey of Iran.

Saccani, E., Delavari, M., Beccaluva, L. \& Amini, S. 2010. Petrological and geochemical constraints on the origin of the Nehbandan ophiolitic complex (eastern Iran): Implication for the evolution of the Sistan Ocean. Lithos 117, 209-28.

Sadeghian, M., Bouchez, J. L., Nedelec, A., Siqueira, R. \& VAlizADEH, M. V. 2005. The granite pluton of Zahedan (SE Iran): a petrological and magnetic fabric study of a syntectonic sill emplaced in a transtensional setting. Journal of Asian Earth Sciences 25, 30127.

SAIDI, A., BRUNET, M.-F. \& RICOU, L.-E. 1997. Continental accretion of the Iran Block to Eurasia as seen from late Paleozoic to early Cretaceous subsidence curves. Geodinamica Acta 10, 189-208.

SARKARINEJAD, K. 2005. Structures and microstructures related to steady-state mantle flow in the Neyriz ophiolite, Iran. Journal of Asian Earth Sciences 25, 85981.

SARKARINEJAD, K. 2007. Quantitative finite strain and kinematic flow analyses along the Zagros transpression zone, Iran. Tectonophysics 442, 49-65.

Schellart, W. P., FreEMAn, J., Stegman, D. R., Moresi, L. \& MAY, D. 2007. Evolution and diversity of subduction zones controlled by slab width. Nature 446, 308-11.

SCHRÖDER, J. W. 1944. Essai sur la structure de l'Iran. Eclogae Geologicae Helvetiae 37, 37-81.

SEARLE, M. \& COX, J. 1999. Tectonic setting, origin, and obduction of the Oman ophiolite. Geological Society of America Bulletin 111, 104-22.

SeArle, M. P., WARren, C. J., WATERs, D. J. \& PARrish, R. R. 2004. Structural evolution, metamorphism and restoration of the Arabian continental margin, Saih Hatat region, Oman Mountains. Journal of Structural Geology 26, 451-73.

SENGÖR, A. M. C. 1990. A new model for the late PalaeozoicMesozoic tectonic evolution of Iran and implications for Oman. In The Geology and Tectonics of the Oman Region (eds A. H. F. Robertson, M. P. Searle \& A. C. Ries), pp. 797-831. Geological Society of London, Special Publication no. 49.

Sengör, A. M. C., Altiner, D., Cin, A., Ustaömer, T. \& HsÜ, K. J. 1988. The origin and assembly of the
Tethyside orogenic collage at the expense of Gondwana land. In Gondwana and Tethys (eds M. G. AudleyCharles \& A. Hallam), pp. 119-81. Geological Society of London, Special Publication no. 37.

SENGÖR, A. M. C., SINAN OZEREN, M., KESKIN, M., SAKINK, M., OZBAKIR, A. D. \& KAYAN, I. 2008. Eastern Turkish high plateau as a small Turkic-type orogen: Implications for post-collisional crust-forming processes in Turkictype orogens. Earth Science Reviews 90, 1-48.

SEPEHR, M. \& Cosgrove, J. W. 2004. Structural framework of the Zagros Fold-Thrust Belt, Iran. Marine and Petroleum Geology 21, 829-43.

Shafait Moghadam, H., Stern, R. J. \& Rahgoshay, M. 2010. The Dehshir ophiolite (central Iran): Geochemical constraints on the origin and evolution of the Inner Zagros ophiolite belt. Geological Society of America Bulletin 122, 1516-47.

Shafait Moghadam, H., Whitechurch, H., RaHgOShaY, M. \& Monsef, I. 2009. Significance of Nain-Baft ophiolitic belt (Iran): Short-lived, transtensional Cretaceous back-arc oceanic basins over the Tethyan subduction zone. Comptes Rendus Geosciences 341, 1016 28.

SHAHABPOUR, J. 2005. Tectonic evolution of the orogenic belt in the region located between Kerman and Neyriz. Journal of Asian Earth Sciences 24, 405-17.

Shahbazi, H., Siebel, W., Pourmoafee, M., GHorbani, M., Sepahi, A. A., Shang, C. K. \& Vousoughi ABEDINI, M. 2010. Geochemistry and U-Pb zircon geochronology of the Alvand plutonic complex in Sanandaj-Sirjan Zone (Iran): New evidence for Jurassic magmatism. Journal of Asian Earth Sciences 39, 66883.

Sheikholeslami, R., Bellon, H., Emami, H., SABZehei, M. \& PIQUE, A. 2003. Nouvelles donnees structurales et datations $40 \mathrm{~K}-40 \mathrm{Ar}$ sur les roches metamorphiques de la region de Neyriz (zone de Sanandaj-Sirjan, Iran meridional). Leur interet dans le cadre du domaine neotethysien du Moyen-Orient: New structural and 40K40Ar data for the metamorphic rocks in Neyriz area (Sanandaj-Sirjan Zone, Southern Iran). Their interest for an overview of the Neo-Tethyan domain in the Middle East. Comptes Rendus Geosciences 335, 981-91.

Sherkati, S., Letouzey, J. \& Frizon De LAmotte, D. 2006. Central Zagros fold-thrust belt (Iran): New insights from seismic data, field observation and sandbox modeling. Tectonics 25, TC4007, doi:10.1029/2004TC001766, 27 pp.

Sherkati, S., Molinaro, M., Frizon De Lamotte, D. \& LETOUZEY, J. 2005. Detachment folding in the Central and Eastern Zagros fold-belt (Iran): salt mobility, multiple detachments and late basement control. Journal of Structural Geology 27, 1680-96.

SHOJAAT, B., HASSANIPAK, A. A., MOBASHER, K. \& GHAZI, A. M. 2003. Petrology, geochemistry and tectonics of the Sabzevar ophiolite, North Central Iran. Journal of Asian Earth Sciences 21, 1053-67.

Smit, J., Brun, J. P., Cloetingh, S. \& Ben-Avraham, Z. 2010a. The rift-like structure and asymmetry of the Dead Sea Fault. Earth and Planetary Science Letters 290, 74-82.

Smit, J., BurG, J.-P., Dolati, A. \& Sokoutis, D. $2010 b$. Effects of mass waste events on thrust wedges: Analogue experiments and application to the Makran accretionary wedge. Tectonics 29, TC3003, doi:10.1029/2009TC002526, 11 pp.

SNYDER, D. B. \& BARAZANGI, M. 1986. Deep crustal structure and flexure of the Arabian plate beneath the 
Zagros collisional mountain belt as inferred from gravity observations. Tectonics 5, 361-73.

StAmpfli, G. M. \& Borel, G. D. 2002. A plate tectonic model for the Paleozoic and Mesozoic constrained by dynamic plate boundaries and restored synthetic oceanic isochrons. Earth and Planetary Science Letters 196, 1733.

Stampfli, G., Marcoux, J. \& Baud, A. 1991. Tethyan margins in space and time. Palaeogeography, Palaeoclimatology, Palaeoecology 87, 373-409.

STÖCKLIN, J. 1968. Structural history and tectonics of Iran: a review. American Association of Petroleum Geologists Bulletin 52, 1229-58.

TAKIN, M. 1972. Iranian Geology and Continental Drift in the Middle East. Nature 235, 147-50.

TAleBIAN, M. \& JACKSON, J. 2002. Offset on the Main Recent Fault of NW Iran and implications for the late Cenozoic tectonics of the Arabia-Eurasia collision zone. Geophysical Journal International 150, 422-39.

TALEBIAN, M. \& JACKSON, J. 2004. A reappraisal of earthquake focal mechanisms and active shortening in the Zagros mountains of Iran. Geophysical Journal International 156, 506-26.

TAPponnier, P., Xu, Z., Roger, F., MeYer, B., Arnaud, N., WiTTLINGER, G. \& YANG, J. 2001. Oblique stepwise rise and growth of the Tibet Plateau. Science 294, 1671-7.

Thiele, O., Alavi, M., Assefi, R., Hushmand-ZadeH, A., SEYED-EMAMI, K. \& ZAHEDI, M. 1968. Golpaygan quadrangle map $(1 / 250,000)$ with explanatory text. Tehran: Geological Survey of Iran.

Thuizat, R., Whitechurch, H., MONTIGNy, R. \& JUteau, T. 1981. K-Ar dating of some infra-ophiolitic metamorphic soles from the Eastern Mediterranean: new evidence for oceanic thrustings before obduction. Earth and Planetary Science Letters 52, 302-10.

TIRrul, R., Bell, I. R., GRIFFis, R. J. \& CAMP, V. E. 1983. The Sistan suture zone of eastern Iran. Geological Society of America Bulletin 49, 134-50.

VAN Hunen, J. \& Allen, M. B. 2011. Continental collision and slab break-off: A comparison of 3-D numerical models with observations. Earth and Planetary Science Letters 302, 27-37.

Verdel, C., WeRnicke, B. P., RAMEZANI, J., HASSANZADEH, J., RenNe, P. R. \& SPELl, T. L. 2007. Geology and thermochronology of Tertiary Cordilleran-style metamorphic core complexes in the Saghand region of central Iran. Geological Society of America Bulletin 119, 961-77.

Vernant, P., Nilforoushan, F., Hatzfeld, D., AbBassi, M. R., Vigny, C., Masson, F., Nankali, H., Martinod, J., Ashtiani, A., Bayer, R., TAVAKoli, F. \& CherY, J. 2004. Present-day crustal deformation and plate kinematics in the Middle East constrained by GPS measurements in Iran and northern Oman. Geophysical Journal International 157, 381-98.
Vincent, S. J., Allen, M. B., Ismail-Zadeh, A. D., Flecker, R., Foland, K. A. \& Simmons, M. D. 2005. Insights from the Talysh of Azerbaijan into the Paleogene evolution of the South Caspian region. Geological Society of America Bulletin 117, 151333.

Von Blanckenburg, F. \& Huw Davies, J. 1995. Slab breakoff: A model for syncollisional magmatism and tectonics in the Alps. Tectonics 14, 120-31.

VRIELYNCK, B. \& BouYsSE, P. 2003. The Changing Face of the Earth. Commission for the Geological Map of the World. Paris: UNESCO Publishing, 32 pp.

WALKER, R. T. 2006. A remote sensing study of active folding and faulting in southern Kerman province, S.E. Iran. Journal of Structural Geology 28, 654-68.

WALKer, R. T., GANS, P., Allen, M. B., JACKSON, J., KhatiB, M., MARSH, N. \& ZARRINKOUB, M. 2009. Late Cenozoic volcanism and rates of active faulting in eastern Iran. Geophysical Journal International 177, 783-805.

WALKER, R. \& JACKSON, J. 2002. Offset and evolution of the Gowk fault, S.E. Iran: a major intra-continental strikeslip system. Journal of Structural Geology 24, 167798.

WAlpersdorf, A., HatzFeld, D., NANKali, H., TAVAKoli, F., Nilforoushan, F., TATAR, M., Vernant, P., ChÉRY, J. \& MASson, F. 2006. Difference in the GPS deformation pattern of North and Central Zagros (Iran). Geophysical Journal International 167, 107788.

Wells, A. J. 1969. The Crush Zone of the Iranian Zagros Mountains, and its implications. Geological Magazine 106, 385-94.

Whitechurch, H., Juteau, T. \& Montigny, R. 1984. The eastern mediterranean ophiolites (Turkey, Syria, Cyprus): their contribution of the history of the NeoTethys. In The Geological Evolution of the Eastern Mediterranean (eds J. E. Dixon \& A. H. F. Robertson), pp. 425-41. Geological Society of London, Special Publication no. 17.

WORTEL, M. J. R. \& SPAKMAN, W. 2000. Subduction and slab detachment in the Mediterranean-Carpathian region. Science 290, 1910-17.

Wrobel-Daveau, J.-C., Ringenbach, J.-C., TaVakoli, S., Ruiz, G., MASSE, P. \& Frizon DE LAMOTTE, D. 2010. Evidence for mantle exhumation along the Arabian margin in the Zagros (Kermanshah area, Iran). Arabian Journal of Geosciences 3, 499-513.

Yamato, P., Agard, P., Goffe, B., De Andrade, V., O., V. \& Jolivet, L. 2007. New, high-precision P$\mathrm{T}$ estimates for Oman blueschists: implications for obduction, nappe stacking and exhumation processes. Journal of Metamorphic Geology 25, 657-82.

Zanchi, A., Berra, F., Mattei, M. R., Ghassemi, M. \& SABOURI, J. 2006. Inversion tectonics in central Alborz, Iran. Journal of Structural Geology 28, 2023-37. 